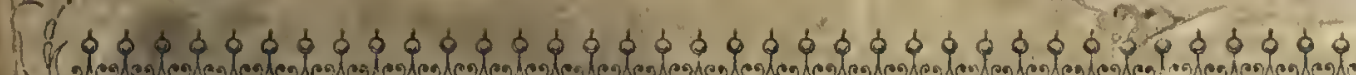

\title{
PRACTICAL HINTS
}

RESPECTING

\section{MOTHS AND BUTTERFLIES,}

WITH NOTICES OF THEIR LOCALITIES:

FORMING

A CALENDAR

ENTOMOLOGICAL OPERATIONS

THROUGHOUT THE YEAR;

IN PURSUIT OF LEPIDOPTERA.

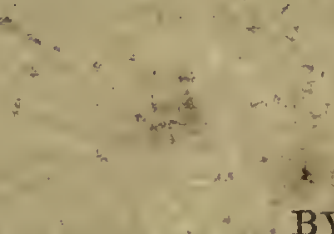

RICHARD SHIELD.

\section{LONDON :}

JOHN VAN VOORST, PATERNOSTER ROW.

1856.

Price]

[Three Shillings. 


\section{ELEMENTS OF ENTOMOLOGY. By W. S. DALIAS, F.I.S.}

Having been repeatedly applied to for a good, cheap, intelligible Work, giving a general view of Entomology, and knowing of none fulfilling these essentials, we have requested Mr. Dallas to prepare one.

Mr. Dallas already enjoys a very high repute amongst scientific Entomologists, but in committing this task to him we laid great stress on the extreme importance of the forthcoming "Elements of Entomology" being not only nell written, but pleasantly written, so that it should appear as attractive as possible to general readers. In the attempt to combine the dulce with the utile, we believe it will be found that Mr. Dallas has completely succeeded.

The price of the "Elements of Entomology," for which a large, steady demand is anticipated, will be made as low as possible, and we can confidently recommend this to the public as a very valuable addition to the series of CHEAP Works on Entomology now in course of publication.

The "Elements of Entomology" will be published in the course of the present summer.

H. T. Stainton.

T. V. WOLLASTON.

March 1st, 1856. 


\section{PRACTICAL HINTS}

RESPEOTING

\section{MOTHS AND BUTTERFLIES,}

WITH NOTICES OF THEIR LOCALITIES:

FORMING

A CALENDAR

oF

\section{ENTOMOLOGICAL OPERATIONS}

THROUGHOUT THE YEAR,

IN PURSUIT OF LEPIDOPTERA.

BY

RICHARD SHIELD.

LONDON :

JOHN VAN VOORST, PATERNOSTER ROW.

1856. 



\section{JANUARY.}

WeLCOME to the new Year! The old year, with its hopes and fears, is gone, and become a thing of the past; but although the year itself has gone, never to return, it has left behind it sunny memories - memories of green fields and leafy woods-of the happy social rambles in pursuit of Nature's beauties; rambles which, besides, supplied us with large draughts of health and joy. The umbrageous wood, the smiling meadow, the music of the rippling stream, as it winds its way over its pebbly bed-the song of the lark, as he rises from his dewy couch, soaring towards the sky, pouring out his little soul in floods of gushing melody, together with the busy stir of insect life, combine to form a scene calculated to produce the holiest hopes, the loftiest aspirations. Cold must be the heart not moved by such a scene-perturbed, indeed, must be the spirit that it would not soothe!

O, Memory! we love to linger with thee: thou bringest to us "voices of the past, shadows of the mighty dead;" thou fillest our souls with gladness, and our hearts with joy; thou incitest us to worthier deeds, to loftier aspirations; thou pointest out to us our shortcomings and errors; thou recallest to our minds the actions of the past, placing them in juxta- 
position with the present, that we may be guided in our conduct now, and its probable effects on the future, by the experience of what has been.

Welcome, new year! A new year, a new hope; new hopes, new fears, new aspirations, new duties: may we use thy moments as a precious trust: if we lose or abuse thee, we are made to suffer for our negligence; "let us work, therefore, while it is day; the night cometh, when no man can work;" we must put forth all our energies, in order to obtain success in whatever pursuit we are engaged, and in nothing is this more true than in regard to entomological science, which is essentially a science of observation. The entomological tyro must not content himself by listlessly walking beside a hedgerow, or threading the mazes of a wood, capturing and observing only such insects as force themselves upon his observation, but he must diligently hunt for them, search them out, explore every crevice and crack in search of the perfect insects, and carefully scrutinize every tree, plant and herb that he comes across, in order to discover the larvæ or evidences of their operations : these will show themselves to the observant and industrious collector in every possible form, mining in blotches and galleries in the leaves, puckering, twisting and folding them in every conceivable manner, agghtutinating the young shoots of plants, and mining beneath the bark of trees; feeding in a variety of ways upon every species of vegetable matter, from the lordly oak of the forest down to the humble lichen upon an old paling.

In order, therefore, to assist the tyro in his observations, I have endeavoured in the following pages, 
under the respective months of the year, to give as succinctly, and in as plain language as possible, the ordinary operations to be performed in doors and in the open air by the Entomological tyro.

The month of January is, to the Entomologist, as far as the imago is concerned, almost a blank; it is, therefore, necessarily the best period of the year which he call select to "set his house in order" for the reception of his numerous guests that he may expect as the season advances; and if he does so he will find that a great deal of valuable time which he could ill spare during the busy summer season will be thereby saved to him.

The tyro who intends to breed insects (and he must do this if he expects to make good progress in Entomology) must provide himself with the following apparatus for rearing the larve of Micro-Lepidoptera, viz. :-several air-tight bottles (there is a bottle made by Messrs. Cook and Crawley, Raven Row, Spitalfields, that is admirably adapted for this purpose, especially for the pupæ of Lithocolletis and Nepticula); it is called the cylinder pattern, and consists of a bottle in the shape of a cylinder, with a wide mouth, fitted with a metal cover, round the inside of the rim of which is a ring of cork : this being flexible, on the cap being placed on the bottle it adapts itself to the shape of the moutl, filling up all the interstices, thus rendering it air-tight; they may be purchased at from about $2 s .6 d$. to $4 s .6 d$. a dozen complete.

2ndly. One or more tin canisters, of any form most convenient for containing larvæ when collected; a large box, or two or three large garden pots, for planting В 2 
therein the roots of such plants as contain larvæ, which require the plant to be kept in a growing state; a few round tin canisters, about nine inches deep by five in diameter, with lids whose rims slip on outside the cases, and with the whole circumference of the lids cut out to within about half-an-inch of the edge; also a box for rearing the pupæ of Micro-Lepidoptera, as follows:

" Obtain one or more boxes of any convenient length or breadth, but not less than six inches in depth (either divided into compartments or not), and fitted with a lid, having a large space cut out of it to within an inch of the margin; this open space to be covered with either close wove wire or old calico affixed with thin glue. In the bottom of the box, or of each compartment, bore with a centre-bit one or more holes, about two-thirds of an inch in diameter; cover these with pieces of perforated zinc, tacked down; place on the bottom of each box or compartment moderately-large pebbles or sea-gravel, to the depth of about half-aninch, and on this again, to the depth of two inches, the earth, on which to lay the pupæ, composed of gardenmould, silver sand, and thoroughly rotten wood from the heart of an old tree; on this, after being made smooth, distribute your pupæ in such a manner, according to their size, that when covered none are more than half-an-inch below the surface, and cover the surface of the mould with a layer of moss, about halfan-inch thick. The insirle of the box should be rough, and the box itself should be raised on pieces of wood, or have pieces of wood fixed to the bottom in such a manner that it may stand clearly above the floor.

"By this arrangement you may damp your pupæ 
with impunity, as it is impossible for them to become saturated with stagnant water, owing to the bottom drainage, and the moss at the top prevents undue evaporation by absorbing a certain quantity of moisture, and thus striking a medium between the two extremes of wet and drought."

Having provided himself with the foregoing, together with a ring-net, as described in the "Entomologist's Companion," 2nd edition, page 3, and a supply of pill-boxes and pins, the tyro is ready to commence his Entomological campaign.

And, now, gentle reader, let us take a ramble together; let us walk in the open country, explore the weedy bank, or peer with curious eyes along the old park-palings' green and mossy space, examining each nook and cranny with minnte attention, and having reached the end, retrace our steps for fear some portion might have escaped our scrutiny; let us examine the twisted leaf, the roll'd-up grass blade, or dig deep into the centre of some ancient gate-post or artiquated paling, for in all these lie concealed the objects of our search.

It is a fine clear morning; the sky is brightly blue and studded with fleecy clouds, that look like a flock of sheep as they gambol along chasing each other before the breeze. 'The milkmen with their shining cans are hurrying about in desperate confusion, calling out "below" at every few paces, as if they expected to fall over some unfortunate pedestrian, and were anxious to give him timely notice of their coming-the peripatetic coffee-shops are going home, some on wheels, others on yokes, and all looking remarkably sleepy 
after their " night-out," while the smell and sound of breakfast (of which we have partaken) ascends in gushes from the kitchens of the various houses, as we hurry on oul' way to the terminus of the "South-Eastern Railway," to catch the quarter past-eight o'clock train for Norwood, "en route" to West Wickham Wood.

Having obtained our tickets and taken our seats, our iron horse soon begins to feel the collar, and with a puff and a snort he commences the journey. "Now we're off!" exclaim one or two of the passengers, which is the maximum of the conversation we may expect to hear until we reach our destination.

Having reached the Norwood station, alighted and given up our tickets to the porter, we recommence our journey on foot, taking the Addington road; and even now we are in good collecting ground, the lanes on our road are bounded by fine hedges, principally composed of whitethorn, privet and dwarf maple, while the banks underneath them are covered with herbage of good growth, consisting of ground-ivy (Glechoma hederacea), flea-bane (Inula dysenterica), burdock (Arctium Lappa), wild strawberry (Fragaria vesca), perforated St. John's Wort (Hypericum perforatum), together with black-knapweed, goose-foot, cow-parsley, mouse-ear chickweed, Artemisia, and a host of other plants, all of which form food for the objects of our search; let us commence:

If we stoop down and examine the grass upon that hedge-bank we shall see that some of the blades, instead of being flat as usual, are rolled up from the bottom upwards, and that some of these rolled leaves are attached by their points to others in their neigh- 
bourhood; if we open some of these we shall find a pretty black and white larva, this is the larva of Gelechia rufescens; by the ditch side in the wet places we shall find the common flea-bane (Inula dysenterica); the larvæ of Gelechia bifractella and Gel. Inopella occur in the seeds of this plant.

But since we have been searching the grass and the Inulce a peculiar aromatic odour has arisen; this is caused by our bruising that trailing plant at our feetthis is the ground-ivy (Glechoma hederacea). If we examine the leaves we shall see white blotches on some of the lower ones-these are caused by the larvæ of Coleophora albitarsella; and if we turn over the leaves thus marked we shall find on many of them the larva itself in its black case; upon the heads of the rushes you will find the larvæ of Coleophora cespititiella, while on the underside of the leaves of the wild strawberry (Fragaria vesca), growing on the loamy bank, the larva of the pretty Lampronia prelatella occurs in its singular case; by its side, on the St. John's Wort (Hypericum perforatum), the larvæ of Gracilaria aurogutteila, having no fear of her Majesty's officers of excise before their eyes, manufacture their " cigars ;" in the seeds of the burdock (Arctium Lappa) the larva of Parasia Lappella reposes in fancied security, while in the stems beneath him the larva of Argyrolepia badiana makes a dainty meal upon the pith.

The thistles (Cirsium palustre) furnish their quota of board and lodging, during the winter months, to the embryo "Phalence," for in their stems the larvæ of Ephippiphora cirsiana and $E$. scutulana have their re- 
treat, and in the stems of the wild parsnip (Pastinaca sativa) the larvæ of Lozopera dilucidana (Stephens) may be found.

And if we examine the neighbouring bramble-leaves, we shall see that the larvæ of Nepticula aurella are industriously employed making their wavy tracks.

But while we have been exploring the seeds of thistles and burdock, and eke their stems, letting daylight in among their astonished inhabitants, to their no small distaste and our great pleasure, we have been insensibly shortening the distance (slowly, but surely) between us and the wood-and here we are at the end of the lanes, and at the south-east corner of the wood, opposite the "Fox" at Shirley, a house celebrated during the lifetime of its late landlord for there always being a "beefsteak pudding" for dinner on Sundays. Full many a time, after a long walk and the anything but appetite-appeasing occupation of collecting, have I walked into the parlour of mine host of the "Fox," and inquired what was for dinner, when, as sure as daylight, the reply was, "Beefsteak pudding, sir ;" and no unwelcome friend, either, under such circumstances; but still it sorely puzzled us how "beefsteak pudding came to be the invariable standing Sunday dish.

But to return from this digression. Adjoining the "Fox," on the right-hand side of the road, runs a park paling, surrounding the Archbishop of Canterbury's demesne, and opposite to this is our destination, "West Wickham Wood." This is a first-rate locality, and when I first knew it, some six or seven years ago, was then comparatively a "terra incognita" to the 
generality of collectors, the questions generally asked being "Have you been to West Wickham?" "Where is West Wickham?" "Do you know where Wcst Wickham is?" While collcctors of a certain stamp used to alight at the Annerley Station, if they thought they had been seen by a less fortunate "brother of the net and pin," in order that the famous "West Wicklam Wood" should remain the exclusive hunting-ground of the fortunate few.

The wool is very extensive, and is composed principally of birch, intermixed with larch, pine, oak, elm, beech, whitethorn, and some fine spruce firs, together with an infinite variety of shrubs and plants of smaller growth. If we follow the road until it turns towards the "Cricketcrs," at Addington, and turn into the Wood on our left, we shall soon see before us a fine avenue of excellent pines; in close proximity to these is the "Heath Field," from a corner" of which a footpath leads to the celebrated "Hypericum ground."

But let us return to our station opposite the "Fox." A little way along the road, opposite the palings, on the edge of the Wood by the roadside, you will see some fine spruce firs. Have you a bag with you? Yes, certainly. Then let us search under these trees, and picking up a few of the larger cones, examine thcir apices; in many of them we shall find a fat larva, surrounded by a resinous exudation, feeding upon the pith of the cone: this is the larva of Coccyx Strobilana. You need not trouble yourself to examine every cone, but fill your bag with them at random, as, although you cannot expect every one to contain a larva, yet, as most of them do, it would be only 
waste of time and destruction of larvæ to examine them all.

Now let us examine the fallen leaves. If we carefully turn over the fallen leaves, we shall probably sec some that have oval pieces cut out of them; this has been done by the larvæ of Incurvaria pectinea and I. muscalella; they are now in pupa, so that there is no chance of seeing them moving about, but you will find the cases on the ground under the leaves, with the pupx in them; they are found among birch and oak leaves.

The pupæ of the Lithocolletides are very readily collected in this way in the fallen leaves of oak and hornbeam, and in this manner the pupæ of those species that feed upon the higher branches of the oak may be readily obtained; besides, we have thus a chance of breeding the scarce species, $L$. irradiella, a specimen of the perfect insect having been bred by the late $\mathrm{Mr}$. Wing "from oak leaves collected near Beckenham in the autumn" (Entomologist's Annual for 1855, p. 81, 2nd ed.)

On the licheny trunks of the trees and on old palings the larvæ of Solenobia inconspicuella may be found, if the day be mild, crawling about in their portable cases.

This is, "par excellence," the best month to obtain the various root-feeding larvæ of Ephippiphora Foneana, Argyrolepia Eneana, \&c.

The head-quarters of $E$. Foneana are at Northfleet (although they may be found sparingly at Charlton sand-pits). Northfleet is best reached by the "North Kent" Rail. Having alighted at the Northfleet Sta- 
tion, you will have to cross a few fields by a footpath leading from the station into the main road, having reached which, turn to the right, and proceed along it until you reach the town of Northfleet; on the left of the road, opposite the town, and by the side of the Thames, you will see some very deep chalk pits: these are Northfleet Pits; a pathway from the road, and bearing to the left, leads you into the pits, whence turning to the right and passing through the tunnel of the tramway, you will be in your collecting ground: it is thickly overgrown with mugwort (Artemisia vulgaris), teazle, thistles, and a great variety of other plants.

On cutting off the stems of some of the plants of $A r$ temisia close to the root, or, if the stems are withered, cutting off the crown of the root, you will see that they are mined down the centre by a larva: this is the work of the larva of Ephippiphora Foneana, which feeds in the roots, and the larva of Dicrorampha Artemisiana has a similar habit upon the same plant.

If we open the heads of teazle growing in the neighbourhood, we shall find a green larva feeding upon the seeds; this is the larva of Eupoecilia Roseana; while upon the same plant, but feeding upon the pith, working its way downwards from the seed head, will be found the larva of the pretty cloak Penthina Gentianana; in the stens of the thistles the larvæ of Myclois cribrum may be found: the larva of this insect is taken plentifully in the stems of the thistles on the banks of the Rochester Canal, near Gravesend.

If we take a walk along the banks of the Paddington Canal, until we arrive within a few score yards of 
"Old Oak Bridge," we shall observe that the banks, almost down to the tow-path, are covered with the ragwort (Senecio Jacobea); if we cut open a few of the roots of this plant, we shall find in them the white larva of the beautiful Argyrolepia Aneana, while the larva of Ephippiphora trigeminana is said to feed on the outside bark of the root of the same plant.

If we search the roots of the yarrow (Achillea millefolium) in places where Dicrorampha plumbagana occurs, we shall find them inhabited by the larva of that insect, while the larva of Dicrorampha sequana feeds within the roots of the "Tansey" (Tanacetun vulgare).

In collecting the root-feeding larvæ of the Dicroramphe and Ephippiphoræ, we shall most likely bring home with us a great deal of moss; in this the larvæ of the Crambidae will be found making silken galleries among the roots, and coming out at night to feed upon the surface, while in the moss growing upon old walls the larvæ of Gelechia affinis may be found together with the larvæ of Eudorea murana.

If we examine old mossy walls exposed to the weather, we shall, on mild days, see a number of pretty striped caterpillars crawling about; these are the larvæ of the marbled beauty (Bryophila perla). The habits of this larva are very interesting, and have been beautifully described by Mr. William Varney in the Transactions of the Entomological Society (Partiv., vol. ii., N. S., p. 117), as follows:-_ On old walls which are exposed to the weather, I have found a great many caterpillars which feed upon the fine particles of a silver colour, which grow upon such places. 
They make their cocoons in the holes of the wall, wcaving a web over the holc, then they bite off bits of stone, brick, mortar or moss, and fix it to the webbing, so that it is difficult to find them out in such places, as the cocoon so nearly resemblcs the wall, brick or mortar to which it joins. They are found in the wintcr months, and when the weather is mild they bite a hole through their cocoons and come out to feed; then they rcturn back to their cells and put out thcir excrements, then they close up the hole, which makes it complete. They do not travel more than four or five inches, or at most a foot from the cell, as they find food close at hand. They generally return to the cell which they had occupied before, but when several of them are feeding near together, they sometimes go into the wrong ones, and some of them cannot find their own cells and arc obliged to wander about till they can find a place to build a new onc. They feed in the morning and return to thcir cells about ninc or ten o'clock, which I have witnessed many times. This morning, Thursday, 5th Fcbruary, 1852, I saw a great many of them fecding upon a brick wall, and I saw threc of them go back to their own cclls and eject their excrement; then they closed up the cntrance as neat as though it had never becn opened. In cold weather they remain in their cocoons thrce or four days, and in very sharp weather as many as nine or ten days or even more, without food; but as soon as the wcather becomes mild they fecl the changc, and break through the cell and feed as fresh as evcr. ' I put one in the wall in a small cavity, and put a picce of glass over it to see how it would begin its cell, and I saw it carry scveral 
threads over the hole. It then bit off several bits of moss and pushed them between the threads until it became quite thick and I could not see it any longer, as the caterpillar was inside the cell. The cells are quite smooth inside. These larvæ are about half or three-quarters of an inch long when they are full grown, and are marked with blue and yellow stripes across the body. They change to a pupa, from which the fly makes its escape in about three weeks, in May. The eggs of these flies are a long while before they produce caterpillars, as the latter do not appear before the latter end of November or the beginning of December, when the weather is damp and cold; and although they are very small they seek for a small cavity in which they construct themselves a nest. They are provided each with sixteen legs; some are of a deeper blue than others, and most of them are marked with blue on each side, a yellow line along the back, and a few small brown spots."

In decayed wood the larvæ of Dasycera sulphurella may be found, while the larvæ of Tinea parasitella and Euplocamus Boleti feed in fungi.

In collecting the larvæ of the stem-feeding species, it is not necessary to cut open every stem to see if it is inhabited by larvæ; but if we suspect that they are thus inhabited, it is best to cut one or two of them down close to the root, and having stripped it of whatever leaves may be upon it, examine its surface carefully in order to see if there are any small round holes in it: if there are, let us cut a length out of it, in the centre of which we must keep the hole; then, slitting the piece of stem lengthwise, we shall see if they are 
inhabited by larvæ or earwigs (Forficula auricularia): if by the former we have no occasion to slit any more, but simply cut in convenient lengths those in which the holes appear.

Having said thus much with respect to collecting larvæ (as far as this month is concerned), I will now say a few words with regard to their treatment afterwards, in order that we may stand the best chance of rearing them to perfection; and first as regards the stem-feeding species.

"Larvæ inhabiting the stems of plants, such as Pastinaca, Cirsium, Arctium, \&c., require no attention beyond keeping them away from heat, in order that the pith on which they feed may not dry up. They are best kept in tin boxes about eight inches high by three inches in diameter, and thus packed together they suffer no injury except in the case of thistles, which are apt to ferment. When this happens they require to be taken out of the tins and exposed to the air until moderately dry, when they may be returned to the tins until within about a month of the time of appearance of the insects; they ought then to be placed in a box with a hole cut in the lid and covered with wire or gauze.

"Larvæ that feed in leaves, such as Nepticula, require the leaves to be rolled in soft paper: when the larvæ are full fed they will quit the leaves and make their cocoons either among them or upon the paper; the latter require to be cut out (attached to portions of either leaf or paper) and kept in small tightly corked bottles. 
"In collecting the pupæ of the genus Lithocolletis, the portion of leaf containing the pupa requires to be cut out, and the pupa (still in the mined portion of the leaf) enclosed in a tightly corked bottle. In this manner they may be kept the whole winter without drying up, provided the bottle is kept constantly closed. (See page 3.)

"The extremely-interesting genus Coleophor a require, in order to obtain success, open-air feeding. The plan I adopt is the following:-I obtain several round tin cases, about nine inches deep by five in diameter. I then cut out the whole circumference of the lid to within about half an inch of its edge (see page 4 ), and procuring a piece of old calico or linen place it flat over the mouth of the tin case. Then put on the lid, pressing it down. This necessarily draws the calico tight, and your Coleoplura breeding-cage is then complete. When wanted for use, put about two inches of earth in the bottom of the tin. In the centre of this put a small tumbler, or wide-mouthed bottle, containing the food placed in water. Put the larvæ on the top of their food; cover them (as before explained). Put the whole out into the open air, in $a$ cool place, out of the reach of the sun, and you will have no reason to complain of want of success, if they are supplied with sufficient food.

"Larvæ that feed in the roots of plants require the foot-plant to be replanted, either in the open ground or in large garden pots, until the end of spring, when they must be taken out of the ground, and placed, with moist earth, in a deep breeding-cage; or if planted 
in pots, both pot and plant can be conveniently set standing in a large breeding-cage until the perfect insects have been bred." *

In concluding this chapter, I have only to remind the tyro of the importance and necessity of diligence and perseverance. He must be Argus-eyed, everwatchful, and acquire a habit of observation and quickness of reasoning upon any facts that may present themselves to him (and of which he may not previously have any knowledge), while practically pursuing the enchanting science of Entomology.

* Natural History Review, Vol. II. Proceedings of Societies, p. 107. 


\section{$(18)$}

C H A P T E R II.

FEBRUARY.

THE following anecdote is related of the late Sir Walter Scott when a child:-A Mrs. Cockburn chatted with him one day. "Aunt Jenny," said he at night, "I like that lady." "What lady," asked Aunt Jenny. "Why, Mrs. Cockburn; for I think she is a virtuoso like myself." "Dear Walter," said Aunt Jenny, "what is a virtuoso?" "Oh, don't you know? Why, it is one that wishes and will know everything." Now, an Entomologist must, as the child expressed it, be "a virtuoso;" he must "wish and will know everything" connected with the objects of his study. He must not be content with a cursory acquaintance with the imago, and a partial and imperfect knowledge of its transformations, but he must determine to "wish and will know everything" respecting them, and that in the most complete and perfect manner that can possibly be attained; and how is this to be done? Is it to be accomplished by reading books on Entomology? In a great measure it is; but the tyro must be cautious as to what books he reads, - as to whether the information contained in them is reliable; if it is not, they are only "blind guides," the study of which will only tend to mystify and mislead him, thus causing him to 
lose much valuable time, as he will not be able to place implicit trust in them. "For" if the trumpet give an uncertain sound, who shall prepare himself for the battle?"'

Is it by practical instruction in the fields and woods? Undoubtedly this is the best, most certain and easy method of instruction for a young Entomologist; and happy and fortunate may the tyro consider himself, who at the commencement of his entomological campaign possesses an entomological friend who will be the companion of his rambles; but he must be one who will be ready to teach you, not one who will snub you, or laugh at every inquiry you make,-one who will impart to the tyro the knowledge he has himself acquired,-who will be ready and willing to help him over his difficulties in the pursuit of that science which they cultivate in common, and from which they derive mutual pleasure,--one who will smooth the path and make pleasant the way he has to tread, opening up to him the wonders and the beauties of the insect world, - stimulating his exertions by a clieering word of praise or commendation, and teaching him to avoid the errors of judgment into which, unaided, he would inevitably fall. Reader, if you should possess such a friend, cherish him; don't let him be weaned from you, or you from him, by idle or' splenetic tales, insinuations or broad hints; but let him refain your confidence, and those who have maligned him will soon perceive that "he is not so bad after all."

But if he be not of this class, shun him,--shun him as you would the ague; for be assured that if in your 
simplicity you give yourself up to his teaching, you will receive as severe a sliaking as if you had had a visit from the before-mentioned denizen of the Essex marshes.

But you may be (and I dare say you are) inclined to ask, how am I to know the difference between the true friend and the useless companion? Easily; if in one of your rambles you accidentally meet an Entomologist armed cap-a-pie with beating-stick and net, busily engaged in beating the trees or bushes, and who, on perceiving your approach "on entomological thoughts intent," sidles as soon as he possibly can down a bye-lane, or into a grove or thicket, shunning your approach as if you had committed some heinous crime (don't follow him) - he is a useless companion.

If, on going into the parlour or other apartment of an inn to obtain refreshment, you see two or three persons, who by their appurtenances are collectors, busily engaged in conversation, but who on your entrance become suddenly "silent as the grave,"-as uncommunicative as scarecrows, and in a violent hurry to depart, don't attempt to enter into conversation with them; for the effort will be useless; they are unprofitable companions.

If, on inquiring of a collector the whereabouts of an entomological locality, he hesitates considerably, or tells you West Wickham Wood is near Oxford, Sanderstead is best reached by the Eastern Counties Rail, and that "Darn" is in the vicinity of the Cambridgeshire fens, that man is hoaxing you. Ask him upon what plants the larva of any particular insect feeds, and he will tell you a plant diametrically opposite. 
Take him a box of insects, and ask him to name them for you, if there are any rare or uncommon insects among them, the chances are that they will receive the names of common ones; this being backed by a proposition to exchange with you for them; not that he "particularly cares about them, but he never" takes anything but good insects, as it is as much trouble to set a common insect as a good one," and he "would much rather exchange for them than take them." Of such sophistry beware.

But if you meet a collector in your rambles that does not shun your company, answers your scientific questions, freely and without restraint, corrects you if wrong in any practical matter,-does not giggle at you if you happen to observe that Argyrolepia AEneana is very rare, or that you have failed to rear the larvæ of Ephippiphora Fceneana (after having had considerable trouble to discover their habitat)-pompously adding, "Ah, you may take hundreds of the larvæ, and won't breed one; it isn't every body that knows how to manage 'em;" but informs you that Argyrolepia Aneana is no longer rare, and explains to you (without egotism) the causes of your failure with the $\mathbb{E}$. Foneana larvæ; this is your entomological friend. Give him a trial; his services will be more valuablehis knowledge more useful to you - than the acquaintance or company of fifty useless companions.

And now having gained an entomological firiend, and, we will suppose, made some progress in Entomology, do not become vain of your acquirements; make no sweeping assertions, but let a humble and 
teachable spirit be sedulously cultivated; and, if a younger entomologist should require information at your hands, do not refuse it, but recall to your mind the time when you were "among the pots," and were craving for information of the same kind; and remember also, that "he that watereth shall be watered."

Now with respect to entomological books, these are of two kinds-good, and good for nothing; those written to instruct, by men well conversant with the subject they treat of, having acquired their knowledge by a long course of study, not only in the library, but practically in the woods and fields from actual observation; and those written by fireside naturalists, whose writings smell more strongly of tea and toast than of the morning air-meditations began and finished by the parlour fire-while the authors " babble of green fields and smiling hedgerows." These are the blind guides; the men who make sweeping assertions without a particle of foundation for them. The following extract, bearing directly upon the subject in hand, will illustrate my meaning; it is from an article on "Mosses and their Allies," inserted in the "Illustrated Magazine of Art" (vol. i. N.S. p. 183): It may be taken in exception, that this is not a strictly Natural History publication, but I would answer that it is a strictly educational one, and, therefore, that accuracy in its statements should be a prominent and leading feature. The author" states that, "Lovely as is this tribe of plants (Mosses), we cannot give a good report of them as ministering directly to the life of any part of the animal creation. They do not furnish nectar for 
the moth or butterfly, nor honey for the bee, nor does any grub or worm find its sustenance from them; and if they are eaten by cattle, or by hares, and other small animals, it is rather by accident than choice." Now here is a sweeping assertion that mosses do not furnish sustenance to any worm or grub, "neither" does any worm or grub find its sustenance from them." Surely the authoress that wrote the paragraph, from which the author deduced the observation above quoted, knew nothing of Entomology; if she had, the assertion would never have been made and quoted, and if not, it was certainly very unwise to make a sweeping assertion on the subject.

Now, it so happens, that instead of no grub or worm finding sustenance from mosses, many species do, and not only species but "genera," as, for instance, "Crambus," and "Eudorea," while several species of Gelechia, together with Noctuce, Bombices, and Geometre, find sustenance from mosses, and, still lower in the scale of vegetable life, from lichens. The following species and "genera" of moths will show that mosses and lichens do not play so unimportant a part as fogd for the lower group of the animal creation. The larva of-

Lithosia rubricollis feeds on moss and lichen on trunks of trees.

* In a residence of eleven months in Melville Island, Sir Edward Parry found only six species (of insects), because lichens and mosses do not afford nourishment for the irisect tribes, though it is probable that every other kind of plant gives food and shelter to more than one species.-Mrs. Somerville's Physical Geography, Vol. ii. p. 139. 
Bryophila perla feeds on the silvery lichen on old walls.

Cleora Lichenaria fceds on lichen on trunks of oaks.

All the species of the genus "Crambus," and the genus "Eudorea," together with the following species of Tineince-

Gelechia desertella 3 Moss on the sand-hills, Che" mundella $\}$ shire.

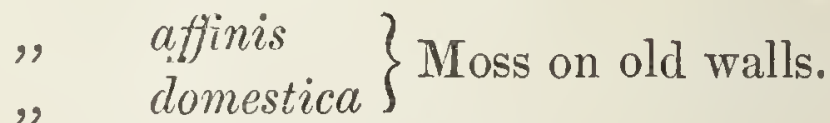

99

" tenebrella. . Moss.

I think these species will be sufficient to show the tyro the folly of making any such sweeping assertion as the forcgoing, as it is extremely probable that there is no plant growing upon the earth that does not furnish sustenancc to some animal or other at some period of its existence, either in its perfect or transition state.

And I would herc caution the tyro against dogmatism. A dogmatic spirit in science shows the ignorance and shallowness of attainments in the man who possesses it in the most striking light; it is not because you see a certain fact or series of facts in a certain light that everybody else is to see them so likewise; and it is the height of injustice and presumption for any man to set his own ideas up as a standard, and quarrel with thosc who presume to differ from thcm, implying, "when I ope my mouth let no dog bark."

And now, gentle reader, let us take a short trip together, and for a while leave the great Babel with all its stir and hubbub, its glitter and noise, behind us, and speed on our way to Plumstead. If we obtain a ticket at the Eastern Counties Railway at Shore- 
ditch, by any of the Woolwich trains, we shall in a very short space of time be located at North Woolwich, from whence we shall be ferried across the River Thames to South Woolwich. Having arrived there we turn to the left, and, following the bearing of the road to the right, we continue our course until we reach an open space; then bearing to the left, and taking the main road, we shall, after we have proceeded some distance, see on our right a fine avenue of pines, and a little further on a goodly wood-this is Plumstead Wood.

Having now arrived at our destination, we prepare to commence operations. It is a fine bracing day; the air, though cool, is by no means unpleasant, and the brisk wind as it flies on its course makes Eolian harmony as it whistles through the tops of the noble pines, which bend their heads in deference; the rustling leaves of "Autumn's sad decay" mingle their cadences, while the robin's merry song, the blackbird's angry chatter, as disturbed at his feast of haws or mountainash berries he daslies through the underwood, together with the monotonous and plaintive call of the bullfinch, or the sprightly movements of the active little blue tits, as suspended, back downwards, they are busily engaged upon the pine cones over our heads, give life and animation to the scene.

The ground is thickly covered with underwood and plants of various growth; whitethorn, sloe, broom and brambles innumerable cover the ground; the vegetation is on the move, the sap is giving evident signs of returning spring, for on the bushes of broom we shall 
see, on their lower branches, the buds enveloped in their downy covering ready to break forth, while shaded in the hollows the brambles are putting forth their fresh buds. I love the bramble, free, easy and independent as he is, rambling o'er hill and dale, through valley and lea, ever and anon catching at the clothes of some incautious traveller, as if to court attention, or combing large tufts of hair from off the wandering cow's sleek sides, wherewith the robin lines her mossy nest in winter. When almost everything amongst vegetable life is in brumal repose, the bramble cheers us with his shining leaves; in summer he throws out bunches of pretty rosaceous flowers, gladdening the heart of the schoolboy as he speculates upon how many of those tiny roses will reach fruition; while in the autumn the black and shining berry, hanging in cluster's among the deep green leaves, bring back to our memories reminiscences of happy days when, with basket on our ar'm and health in our cheek, we rambled in pursuit of them.

"Thy fruit full well the school-boy knows,

Wild bramble of the brake;

So put thou forth thy small white rose, I love it for his sake.

"Though woodbines flaunt and roses blow O'er all the fragrant bowers,

Thou need'st not be asham'd to show Thy satin-threaded flowers.

"For dull the eye, the heart is dull,

That cannot feel how fair, Amid all beauty, beautiful,

Thy tender blossoms are. 
"And thou, wild bramble, back dost bring,

In all thy beauteous power,

The fresh green days of life's fond spring,

And boyhood's blossomy hour.

"Again, thou bidd'st me be a boy,

More fair than bird or bee,

To gad in freedom and in joy,

O'er bank and brae with thee."*

Having fitted our nets and procured a beating-stick, if we have not brought one with us, we commence operations; and first the pines are the objects of our scrutiny. Holding our nets under the branches with the left hand, we proceed gently to strike the branches with the beating-stick in our right, carefully catching whatever falls in our nets; having well beaten one branch we proceed to another and another, treating them all in the same manner, until we have operated upon all that are within our reach upon the tree. The nets being now well covered at the bottom with what has fallen from the tree during the beating process, we proceed to examine its contents: having laid the net upon the ground, and (if it be a bag net) partially turned it inside out, or (if a clap net) spread it open, we proceed to examine its contents; and truly there is a goodly assortment-spider's, earwigs, beetles, gnats, and Diptera of various kinds, together with larvæ, commence a mutual race, each anxious to secure for himself a safe retreat, of the precise locality of which he is at present oblivious. It is amusing, during this helter skelter, to see an active Jittle beetle, in his haste to escape, running foul of a spider, whom, under other

* Elliott. 
circumstances, he would most carefully avoid, while the earwigs chase each other, meeting with occasional tumbles during their rapid progress, contrasting strongly with the slow and measured tread of the Geometra. larvæ as tliey slowly emerge from the heap of debris below. On examining the contents of the net we shall find a pretty green larva (a Geometra); this is the larva of Thera variaria. If we turn out some of the rubbish, carefully examining it as we proceed, we shall most likely see some small fleshy looking flat circular objects, with silvery looking dots upon them: if we take one in our hand we shall find it is a Geometra larva coiled up into this spiral form; this is caused partly, perhaps, for the purpose of concealment, and partly fiom cold; for if we hold one of them in our hands for a short time, or put one of them in a pill-box into our pocket, we shall, after a time, find he has uncoiled himself and become more active, and that the silvery spots have become brighter; this is the larvæ of the Red Bar (Ellopia fasciaria). But what are those little brown clouded moths flitting about among those oaks, now settling upon the leafless branches, and now threading their way among the herbage? this is the pretty, but common, little tortrix (Tortricodes Hyemana). If we look closely at the bark of that rugged oak we shall see in the crevices a dark object; on closer examination we see it is a moth with its wings crossed; this is the male of Anisopteryx Ascularia: while if we look lower down the trunk we may perhaps see a dark wingless (apterous) object; this is the female of the above "Anisopteryx Ascularia," and in the same situations, upon the trunks of the 
trees, Hibernia leucophearia and $H$. rupicapraria may be found, together with their apterous females.

Let us now diversify our employment a little, and see if we cannot find a few pupæ; and first let us pay a visit to those alders yonder, with their green mossy trunks so invitingly placed towards us. But what are you about? detaching the moss from the tree! Yes, but in what manner? you have begun where you ought to liave finished, at the bottom, thus running the risk of losing whatever pupæ may be loosc in the moss by their falling to the earth. In stripping the trunk of a tree of its moss to search for pupæ, always begin at the upper part, and in this fashion take a portion, say of five or six inches in width, and with both hands, one on each sidc, commence tearing the moss off gently, working downwards, and keeping the moss in a shect as much as possible (not tearing it off in strips), and occasionally shaking it to see if there are any loose pupæ in it ; if there is, they will roll down and be caught in the hollow formed by the detached moss and the trunk of the tree. Now just give the moss a slight shake; sce, there are two or three black pupæ in the hollow and several more hauging by the anal segnent to the moss; these are the pupæx of $Y$ psipetes impluviaria: but what is that small protuberancc on the trunk, that appears as if it were made of dark whiteybrown paper, with a few pieces of moss attached to it; this is the cocoon of Odontopera bidentaria. You will probably find the same kind of cocoon upon the trunks of the pines, while under the moss that clothes the spreading roots of the beech the brown pupæ of Polypogon grisealis will be found, and among the moss 
upon the stumps of the neighbouring felled trees, near the moist rotting wood, the pupæ of Eupithecia austeraria may be obtained; while from under the loose bark of the sycamore a goodly number of the pupæ of Stigmonota Trauniana may be brought to light.

Among the brambles, mining in the leaves, the larva of Nepticula Aurella will be seen, while among the grass, in rolled-up leaves, the larva of Gel.rufescens occurs.

If we examine the rotting or decayed wood of felled trees, we may perhaps find the "pale greenish blackspotted larva of Gelechia luculella-the discovery of this was attended with melancholy results, for it was whilst seeking for this larva that the late $\mathrm{Mr}$. Wing contracted a cold, which suddenly brought the disease (diabetes), which must long have been lurking in his system, to a crisis."

On mossy walls the larva of Gelechia affinis, together with that of Gel. domestica, may still be found.

If we examine the stems of Arundo phragmites growing in that wet ditch, we shall find them inhabited by the larvæ of Chilo phragmitellus, and, by their side, in the stems of Poa aquatica, the larvæ of Chilo forficellus will be found, while on the heads of the neighbouring rushes you will see the case-bearing larvæ of Coleophora ccespititiella, and under the moss, upon the ground, the larvæ of Crambus hortuellus will be found in their silken galleries.

Under the moss on walls in the north of England we shall find the larvæ of Eudorea murana; while that pest of the bee-keeper, the larvæ of Achroea grisella, will be found, much too abundantly, in bee hives, feeding upon the wax. 
If we examine the fallen leaves of oak, beech and hornbeam, we shall find in oak leaves the pupæ of the following Lithocolletides-Roboris, hortella, Amyotella, lautella, quercifoliella, Hegeeriella and Cramerella; in the leaves of beech, the pupa of L. faginella; in hornbeam leaves, on the upper side, the pupa of L. carpinicolella, and on the under side that of $L$. tenella, while in the leaves of the evergreen oaks the young larve of $L$. Messaniella will be found.

On old palings and licheny trunks of trees the larvæ of Solenobia inconspicuella may be found crawling about if the day be fine; while in the fungi on the trunks of the trees the larvæ of Tinea parasitella and Euplocamus Boleti may be found; below the seeds of the carline thistle (Carlina vulgaris), the larva of Parasia Carlinella reposes in fancied security, while in the seeds of the neighbouring burdocks (Arctium lappa) the larva of Parasia Lapvella lies entrenched within the hooked enclosure.

In cases, under the leaves of the wild strawberry (Fragaria resca), the larvæ of the pretty Lampronia prelutella may perhaps be found; while in sheltered places, under the leaves of the ground-ivy (Glechoma hederacea), we may most likely meet with the larvæ of Coleophora albitarsella in their black cases.

Among the St. John's wort (Hypericum perforatum), upon the sandy hedge-bank, we shall find the " cigar" manufactory of Messis. Gracilaria auroguttella in full work; while if we search the rotten wood in the hedge-row we shall eliminate many of the larvæ of Dasycera sulphurella from their moist abode. Among seeds we shall find the larvæ of QEcopleora 
pseudospretella and Endrosis fenestrella, while in grains of barley the larva of Gelechia cerealella revels in plenty, troubled by no fears of impending scarcity.

Having now noticed the most prominent or most necessary species for this month, the majority of which are identical with those mentioned in the chapter on January, I would now only remind the tyro of the necessity of application, of not allowing jealousies or heart-burnings to spring up between himself and other " brethren of the net and pin," to raise a storm upon the otherwise calm sea of Entomology; but to walk humbly and teachably-ever willing to teach according to his ability, and to receive instruction himself-that instruction of which we all stand so much in needthe knowledge of the transformations of the various and beautiful member's of the insect world, of those beautiful atoms of God's creation, each in its appointed sphere fulfilling the purpose for which it was created, drawing forth our wonder, our admiration, and our praise; for " he who wondereth at nothing hath no capabilities of bliss, but he that scrutinizeth trifles hath a store of pleasure to his hand, and happy and wise is the man to whose mind a trifle existeth not." 


\section{( 33 )}

\section{CHAPTER III.}

\section{MARCH.}

WE are now entering upon our Entomological campaign in good earnest; sharp, biting January has passed, and "February fill dyke" no longer throws his snowy mantle over the earth, burying the face of nature under a garment of dazzling whiteness-but still, although we have entered upon a spring month, we are reminded by unmistakeable signs that it is the first of them, for stern old winter still does battle bravely for the ascendancy--disputing with blue-eyed spring the dominion of this hemisphere - resolutely refusing to retire to his icy northern caves without a struggle. No sooner does spring with mild and genial hand " unlock the icy fetters of the brook" - cause the sap to rise, and entice the pale primrose to unfold its buds--than "whew" with the force of an avalanche, and the malice of a fury, the icy tyrant sends forth from his gelid caves the furious northern blast, withering all beneath its paralyzing touch-and so the battle rages, spring meekly retiring before the onslaught of her merciless opponent, until, worn out with useless bluster, and the gentle, but effectual, power of his meek-eyed rival, the northern bully retires to his icy caves and spring resumes her sway. 
And now, with returning spring, the country begins to wear a smiling face, the young and tender buds of the hawthorn, if the weather is mild, begin to show themselves, ornamenting the young wood with little green spots; the birch, too, puts forth her shiny buds, in which the larvæ of Argyresthia Goeclartella and Argyresthia Brockeella live at ease, making a dainty meal upon the yet unexpanded leaves, as well as under its shiny bark-while in open places in the woods, at the root of the forest monarch, the pretty little "wind-flower" (Anemone nemorosa) opens its delicate white flowers to the yet feeble beams of the sun, closing them immediately if but a cloud obscures his brightness, while on the hedge-bank, sheltered by the overhanging whitethor'n, the modest violet "ope's her pale blue e'e," and lower down, in the moist places on the ditch side, nestled amid tufts of rushes and rank grass, the primrose, "sweet harbinger of spring," puts forth her attractive and beautiful yellow blossoms.

"Welcome, pale primrose starting up between

Dead matted leaves of ash and oak, that strew

The every lawn, the wood, and shining through,

'Mid creeping moss and ivy's darker green;

How much thy presence beautifies the ground!

How sweet thy modest, unaffected pride,

Glows on the sunny bank and wood's warm side."

The insect world now begins to feel the effect of the returning spring; for many of those that liybernate during the winter season now begin to move, and may be seen flitting heavily along the hedges at dusk, or busily engaged upon that "bonne bouche" the sallow blossoms; or, if the Entomologist has been sugaring, 
he need not be surprised to find, instead of an early Noctua, a wasted specimen of Depressaria Arenella, ocellana or applana, enjoying the sweets of life with evident satisfaction.

And this leads me to speak of sugaring, and the processes employed to bring within our reach those nocturnal wanderers, which, being but seldom seen in the daytime asleep on palings or trunks of trees, but betaking themselves to the thick underwood, from which they cannot be beaten out, or crawling into tufts of thick grass or herbage at the roots of bushes, or at the stems of trees, and in the herbage of hedge-banks, defy the keenest entomological eye to detect their whereabouts.

And, first, as to sugaring: it is perfectly evident that moths have peculiar predilections, and that they are guided in their taste by some law from which they do not deviate. I have heard it stated by old collectors that "it is no use sugaring while the apple trees are in blossom, for they are so surfeited by feeding at them that thcy will not come to sugar." Now if this be the case, which it certainly is, there must be some cause for the occurrence; for if there were not, we should not see the effect. Now I believe that nearly all the trees or blossoms which prove so attractive to moths during the spring months are almond-scented; thus, for instance, the apple and pear, and the flowers of the syringa or lilac, the latter especially, smell pretty strongly of almonds, while it is well known that the moths will feed upon the berries of the yew, and the flowers of the ivy and sallow, until they become quite intoxicated as it were, and will suffer themselves to be 
transferred to pill-boxes without the least resistance; but this does not happen at sugar, unless the insect has mbibed a considerable quantity of it, as I have seen them fly off it repeatedly before I could capture them, or as soon as they "smelt" danger drop headlong to the ground in the semblance of death.

Now cannot we rival the establishment of Messrs. Pomona \& Co., and present the various members of the Phalana world with an article that will suit their taste as well as that supplied by the before-mentioned establishment: I think so, and would recommend the following "sugar" -

Ale . . . . Half-a-pint (nearly).

Common Honey $\frac{1}{2} \mathrm{lb}$.

Foots . . . . $\frac{1}{4} \mathrm{lb}$.

Rum . . . Half a wine-glassful.

Essential oil of Bitter
Almonds . . . $\} 5$ drops.

To mix this "sugar" make the ale quite hot, nearly boiling, then dissolve in it the honey and sugar; add the essential oil of bitter almonds to the rum, and mix with the honey, sugar and ale, when quite cold: this must be applied in broad streaks, with a brush, lengthways upon the trunks of trees, upon their shady side, or upon stones, posts, felled timber, \&c., a short time before dusk; and when the swifts or "ghost" moths ("Hepialide") begin to fly, you may be sure that those insects that will visit your sugar are preparing to start from their hiding-places-the tyro must then visit with a lantern his trees, or the other places he has sugared, in succession, and he will find the moths sitting on the sugar busily engaged in appropriating it 
to their own personal use; they will continue to come for several hours after sunset. Windy or damp evenings, with little moonlight, are the best nights to sugar, as then moths fly low.

Numbers of moths that will not come to sugar are attracted by light; one or two candles or a bull's-eye lantern, placerl at an open window, will draw them within its influence, when, upon entering the room at the open window, they will immediately mount to the ceiling, where they may easily be captured with a net.

Smoke is also a most excellent method of obtaining insects: by saturating a weedy bank or thick bush with the smoke of tobacco, rags, or brown paper, the insects concealed therein will come creeping out in a semi-sluggish state, and may then be easily captured in pill-boxes. The best way to apply smoke is with the "patent fumigating bellows" (which may be obtained of most ironmongers, or at the principal seed shops). Having put into the chamber of the bellows your tobacco, rags or brown paper, and lit them, close the chamber, and, upon turning the handle upon the top of the bellows, a blast will be produced which will drive out the smoke at the nosle amongst the herbage with considerable force; the instrument is very compact, and may be carried in a moderate-sized pocket. Gelechia pictella and Peronea permutana have been obtained by this method on Barnes Common.

Having now enumerated the methods employed to capture such insects as elude our pursuit by the ordinary methods, we will take a stroll together, and the locality to which I purpose taking you is Sanderstead and its neighbourhood. 
Having procured our tickets at the station of the London, Brighton and South Coast Railway for Croydon, we shall, after a short ride, find ourselves located in that town; if we turn to the left (on leaving the railway station) and continue our route straight through the town and along the main road for about a mile or a mile and a half, we shall see on our left a steep ascent rising from the road to a considerable height and thickly wooded. Although the trees are mostly of a young grow th, there is a considerable quantity of underwood, and in the farther corner a good sized heath field; on the right of the main road, opposite the wooded acclivity, there is a gate at the end of a path leading to a farm-house: by pursuing this path you will arrive at Sanderstead Downs; the wooded acclivity is "Coomb Hurst." The other locality in this neighbourhood is the "Old Tram-road" leading to Sanderstead.

Having arrived at our destination, let us commence operations; and, first, we will examine the trunks of those elms. Ah! what is this large-sized pale-brown insect, with fine wary fascia-formed lines across the wings? that is the male of Phigalia pilosaria, and if we search the trunks carefully, we shall probably find, near the place we found the male, the apterous female of the same insect; the female of this insect is conspicuous from its large size. If we continue our search we shall find in like situations Hibernia leucophearia, and H.rupicapraria, and Nyssia hispidaria, together with the not uncommon Ceropacha flavicornis.

But let us have a look at the pines: hold your net under the branches and beat them carefully. Stay, 
what is that that has fallen as if dead into your net? What a beautiful creature! This is Trachea piniperda; its favourite resting-place is the trunks of the pines, but it sometimes (especially if the weather is sharp) nestles in the branches; while close to the ground, on the trunks of the trees, the pretty Eriogaster lanestris may be found; and in the hedges at Sanderstead, near the Railway Arches, the handsome and scarce Lobophora polycommaria may be obtained by beating.

If we visit the sallow blossoms in the evening with a lantern, we shall find them frequented by Taniocampa rubricosa, miniosa and cruda, accompanied by the resuscitated Depressarice arenella, ocellana and applana.

On the trunks of trees, palings, \&c., we shall find, pressed almost flat to their surface, Chimabacche Fagella, together with his short-winged female, while by beating the oaks the pretty little Heusimene fimbriana may be obtained, and if the day be bright we shall see the males of Dasystoma Sulicella flying in the sunshine; those insects, the larvæ of which have fed upon birch or oak, have a much more rosy appearance than those whose larvæ have fed upon sallow, the latter being much blacker; their semi-apterous females may be found upon the trunks of the trees.

In houses we shall find that pest of the housewife, Tinea pellionella, the larva of which commits such ravages among her stores of woollens and furs, together with the pretty white-shouldered Endrosis fenestrella, which from its conspicuous appearance and locality has been branded as the real depredator.

"Thus justice, while she works at crimes,

Stumbles on innocence sometimes." 
On moors in the north of England, Butalis incongruella may be found; and among the short grass on Arthur's Seat (near Edinburgh) Elachista consortella occurs, while on palings in the neighbourhood of brambles, we shall find the large and handsome $N e p$ ticula aurella, and among wild roses at "Darn" Spilonota pauperana occurs, and, on trunks of trees and palings among birches, Semioscopis Avellanella may be found.

On the pines the larvæ of Thera variaria and Ellopia fasciaria may be found; and in the spruce fir. cones the larva of Coccyx Strobilana is still feeding; these may be obtained in plenty at "Purley," where they were first discovered.

On the licheny trunks of the trees and on old palings, the larvæ of Solenobia inconspicuella may be found; while under the moss on decaying trees we shall find the pupæ of Lithosia rubricollis in plenty.

In the fungi on old trees we shall find the larvæ of Euplocamus Boleti and Tinea parasitella; while in cases among the dead leaves of the birch and oak, we find the pupæ of Incurraria muscalella and $T$. pectinea, together with the larvæ of Incurvaria Oehlmanniella; under the leaves of the wild strawberry (Fragaria vesca), we shall still find the larva of Lampronia pralatella in its curious case; while in the open places among the trees, among the pretty little "wind flower" (Anemone nemorosa), the larva of Adela Degeerella occurs.

Now let us search the broom (Spartium scoparium), just beginning to show the power of the returning spring by putting forth its dark green leaves and 
downy buds; on this we shall find the larva of $D e$ pressaria assimilella. Stay! don't beat the plants; if you do, you will most likely lose more larvæ than you capture, but search them thus:-Take a handful of the twigs of the broom in your left hand, and taking a spray in the right, examine it between the twigs; you will then perhaps see two of them drawn almost close together and a white web spun between them; in this web you will find a brown larva with a black head-this is the larva of Depressaria assimilella, but its presence is not always betrayed by a web, as it often draws two twigs together, feeding between so that the web is not visible, but then the joined stems have a brown appearance where the larva is. In collecting these larvæ do not take them out of their web, but cut the joined twigs out in sufficient lengths with the larvæ undisturbed. I have found this larva in the south of Ireland as early as February. If we examine the broom twigs, towards their points we shall observe a brown streak running round them towards the top; this is caused by the larva of Cemiostoma spartifoliella mining and feeding beneath the bark, while the larva of Depressaria assimilella feeds on the bark.

In the rolled-up leaves of grass upon the hedgebank, the larva of Gelechia rufescens will be found, while in the young shoots of the greater stichwort (Stellaria holostea) the pretty pink-striped larva of Gelechia tricolorella will be found, devouring the young budding leaves, moving from shoot to shoot as he exhausts his supply of food, and in cases on the heads of the wild marjorum (Origanum vulgare), the case-making larva of Gelechia suborellea may be 
found; and on the under side of the leaves of the ground-ivy (Glechoma hederacea) we shall find the larva of Coleophora albitarsella in its black case, making white blotches in the leaves; while on the Hypericum perforatum the "cigars" of Gracilaria auroguttella may still be obtained.

In the decayed wood lying in that moist place we shall find the larva of Dasycera Sulphurella, and probably the larva of the rarer Ecophora unitella may reward our' search.

Among seeds we may find the larvæ of Ecophora pseudospretella and Endrosis fenestrella, while in grains of barley the larva of Gelechia cercalella lies concealed, devouring the fecula: this larva is most destructive in granaries. "In France, this 'Tinea' has proved very destructive to corn-wheat, barley and rye being indiscriminately attacked by it. Duponchel, quoting from the Memoirs of Reaumur, Duhamel, Dumonceau and Tillet, on its natural history, informs us that the female lays her eggs on the grains of these three kinds of corn before they are ripe; six or seven days afterwards, the caterpillars appear, being hardly as thick as a hair, and each one attacks a grain, introducing itself into it by a hole so small, that it is not visible to the naked eye. Here it lives, taking care not to break the husk of the grain, so that the affected seeds cannot be distinguished from the sound, except by putting them into water, when the former swim and the latter sink. When arrived at perfection, the caterpillar, still within the grain that has afforded it food, spins a cocoon of white silk, having first taken the precaution to gnaw one of the ends in such a manner as to 
form a kind of operculum, which readily yields to the efforts of the moth to escape from its prison. This escape usually takes place after the corn is thrashed and laid up in granaries, but specimens sometimes appear before this is accomplished.

"Several methods for preventing or diminishing the ravages of this 'Tinea' have been suggested, the principal being exposure in machines to heat or carbonic gas. In the former it was found that corn would germinate after exposure to a temperature of 70 degrees, Reaumur, and that a higher temperature, 76 to 96 degrees, for a short period, was less effectual in accomplishing the destruction of the larvæ than a lower one, 45 to 50 degrees, continued for a longer time. In the other method, the corn has been found not to be deteriorated for making bread, nor to have lost the power of germinating.

"I am not aware that this insect, which appears to be a great pest in granaries in France, has been obserred in similar places in this country, though, from the ignorance of insects generally among those most immediately affected by their ravages, it may exist in plenty without having been distinguished from other moths whose larvæ feed on grain. My own is the only British specimen I have seen." (Mr. J. W. Douglas on the British Species of the Genus Gelechia of Zeller, Transactions, Entomological Society, vol. 1, N. S., p. 7.)

Since the above was written by that indefatigable entomologist, J. W. Douglas, Esq., the insect has been bred in plenty by Mr. J. Scott, of Renfrew.

If we examine the seeds of the burdock (Arctium 
Lappa) we shall find the larva of Parasia Lappella snugly ensconced within, while in the stems of the same plant the larva of Argyrolepia badiana is still feeding upon the pith, and in the stems of the wild parsnip (Pastinaca sativa) the white larva of Cochylis dilucidana may still be found.

On the leaves of the black fetid horehound ( $\mathrm{Bal}$ lota nigra), and those of the hedge woundwort (Stachys sylvatica), the larva of Coleophora lineolea may be found, and on the heads of the neighbouring rushes the larva of Coleophora ccespititiella is still feeding, while mining in long dark lines in the leaves of Bromus asper or Brachypodium sylvaticum, growing by the ditch side, the larva of Elachista Megerlella occurs, four or five larvæ sometimes mining in one leaf.

On the old tram-road, in the holes once occupied by the sleepers, but now filled with vegetation, the larva of Lithocolletis Scabiosella occurs, mining in the leaves of Scabiosa columbaria; while mining in the leaves of the common Sun cistus (Helianthemum vulgare) the larvæ of Laverna Staintonii may be found; and in the leaves of the brambles the larva of Nepticula aurella may be noticed, forming their serpentine tracks.

In the young shoots of honeysuckle or Charophyllum, and between united ivy leaves, we shall find the larvæ of Tortrix adjunctana, while on the under side of the leaves of the ground ivy (Glechoma hederacea) we shall find enclosed in a slight web the white larvæ of Scopula olivalis.

Let us now search the grass growing upon that 
hedge bank, and let us do it carefully: take up by the roots a tuft of that soft, velvety-looking grass at your feet; if you hold it between your eye and the light, you will perceive them mined in broad streaks of a whitish colour, in which there is very little excrement; this is the mine of Elachista rufocinerea, the larvæ of which you will perceive at the end of the mine; the grass is Holcus mollis, a grass of bad quality, although of good appearance, disliked by cattle, and indicative of bad pastures.

If we examine the leaves of Dactylis glomerata we shall find that many of them are mined from the points downwards; but instead of the leaf remaining flat, it is slightly rounded, owing to the epidermis on the front of the leaf being puckered or laid in folds similar to the mine of a Lithocolletis; this is the work of the larva of Elachista gangabella; it occurs near Beckenham, and sometimes feeds on Holcus mollis; it moves readily from leaf to leaf:

If we search the leaves of Carex glanca growing in the shelter of bushes, we shall probably find the beautiful red-spotted larvæ of Elachista cinereopunctella mining downwards from the tips of the leaves, in which they have apparently wintered; it occurs prolifically among the junipers on Sanderstead Downs: the pupæ are situated at the base of the leaves, in which situation they may be readily collected.

In the stems of the reeds (Arundo phragmites) growing in yon wet ditch, the larvæ of Chilo phragmitellus occur; while in the stems of the reed meadow-grass growing by their side the larvæ of Chilo forficellus will be found; in the damp moss by the ditch side we 
shall find the larvæ of Crambus hortuellus, culmellus and tristellus; while in the moss growing upon the thatch of the neighbouring barn the larvæ of Crambus falsellus may be found; and in the boggy places, in the seeds of the flea bane (Inula dysenterica) the larvæ of Gelechia bifractella and Gel. inopella occur; while in the fallen leaves of oak and hornbeam the pupæ of the Lithocolletides may be obtained, as enumerated last month.

On palings near Convolvolus sepium we shall find Pterophorus pterodactytus; while in houses, playing upon the windows, and flying along hedges among honeysuckle, we shall find the pretty and delicate Alucitina polydactyla.

And now, if the tyro has neglected to do anything that ought to have been done at the commencement of the year, he must delay it no longer: if he has neglected to provide breeding-cages and air-tiglit bottles or jars for his pupæ or larvæ; strips of smooth flat cork for his setting-boards; pins of various sizes for his insects (these may be obtained of Edelsten and Williams, Crown Court, Cheapside, London; they are sold in half-ounce boxes, and entomologists in the country can have them forwarded by post : the proper sizes to order are-

No. 6, for Sphinges and Bombices;

No. 8, for Noctuce;

No. 8 and No. 10, for Geometra;

Nos. 19 and 20, for Micro-Lepidoptera;)

small boxes, either of wood or tin, corked at bottom and top, and covered, in the case of the wooden ones, with smooth paper, for carrying in the pocket on an 
entomological excursion, to place such insects in as are sufficiently large to pin when captured: the cork in the tir ones should not be papered, as they are very useful for keeping such insects as may be placed in them in a relaxed state. It often happens that a collector, during the busy summer season, captures a number of Geometra, Pyrales, large Tortrices, \&c., which are duly pinned and placed by the collector in his pocket collecting-box; the majority of them soon become defunct: this often happens upon a hot July day, when the heat of the weather and the warmth of the pocket combined soon renders the dead specimens too rigid for the collector to set out, on his return from his entomological excursion : this inconvenience is obviated by the tin pocket collecting-box. Provide one or more light tin boxes, hinged, and made to shut together in the same manner as the wooden ones, but as tight as possible; cork the bottom and top with smooth cork, affixed with marine glue or patent liquid glue (the latter is made by dissolving shellac in spirit of wine until it becomes of the consistence of cream), as these resist the action of water, and the box is complete.

When about to use it, fill it with water from some spring or brook, close the lid, and give it a few turns over, until you think the cork is sufficiently damp; then turn the water out, and if there is any superabundant moisture, remove it with your pocket handkerchief, but do not dry it, and it is ready for use. Insects placed in this box will after death be kept in a relaxed state for a considerable time, and a good deal 
of trouble will thus be saved to the collector, as well as time.

And I would now say a word to the tyro at the commencement of the season to avoid carelessness and inattention: it is lost labour, as far as entomology is concerned, to go out into the woods and fields, collect a number of larvæ, bring them home, put them, with their food, into his breeding-cages, and leave them to chance. This will not do: they must be supplied with fresh food often as the other gets stale; it must never be allowed to get mouldy; if it does, the larvæ soon become sickly, and eventually die. The food should never be put into air-tight jars, damp with rain, as this will infallibly cause it to mould, and the mined parts of the leaves in which the pupæ of the Lithocolletides are contained, if cut out of dead leaves collected on the ground, should be exposed to the air for a day or two, or laid open on a plate in a warm room for a few hours before being finally placed in the breedingglasses. 


\section{( 49 )}

\section{CHAPTER IV.}

\section{APRIL.}

April ! coquettish A pril !--season of smiles and tearshas come, borne on the wings of balmy spring, to woo nature from her repose, to deck her in her attire of freshest green, and present her fair and faultless to her thankful worshippers; now drenching her with tears of balmy sweetness, and anon wooing her with sunny smiles-coaxing the young bud with mild and persuasive eloquence to quit the shelter of its downy sheath, and show its new-fledged beauties to the world-opening the tiny blossom of the sloe ere yet a leaf appears upon its spiny limbs-decking the noble apple trees with a garment of frosted silver-while the blushing blossoms of the almond smile a welcome as they wave gracefully in the breeze, and from every copse and shady grove a thousand feathered choristers pour forth their hymns of praise, all nature joining in the great ovation.

"I love thee, Nature, as a child

Loves the dear mother that beguil'd

Its many tedious hours of pain,

And soothed it into health again.

"I'll never, Nature, bid farewell

To thee : thou in my brain shalt dwell

'Till mind shall have outgrown its clay,

And left its garment to decay." -J. W. D. 
How like our life is an A pril day; changeable, fickle and uncertain, composed of hopes and fears, joys and sorrows, clouds and sunshine, smiles and tears : grieving over some sorrow, bowed down by some calamity, we are, perhaps, tempted to repine-but when the misfortune presses hardest upon us, and the grief is nearest to our hearts, when all around seems dark and hopeless, the cloud rolls away-sunshine beams upon our path-and the smile is upon our lip, while the tear dims our eye; "nil desperandum," never despair-have faith-faith in yourself-faith in your friends:

"Have faith in one another,

For should doubt alone incline, It would make this world a desert,

Where the sun would never shine.

We have all some transient sorrow

That o' ercloudeth us to-day;

But have faith in one another,

And it soon shall pass away.

"Have faith in one another,

And let honour be your ģuide;

Let the truth alone be spoken,

Whatever may betide.

Though the false may reign a season,

And oh ! doubt not but it will-

Have faith in one another,

And the truth shall triumph still."

T. E. Carpenter.

Humility and industry must be the allies of geniusindustry, steady unflinching industry-not that kind of fuming industry that tries to crowd the work of a year into the space of an hour, attempting, like Prospero's Ariel, to place a girdle round the earth in forty 
ninutes, and, finding the effort useless, sinks into inanity, but a steady, persevering industry, having an object in view, and trying by all means to attain it. Now, I suppose that many of my readers are working men, who liave taken up the study of Entomology as a relaxation after the severer toils of life-but shall it be a relaxation only - a mere toy? Is not the study of the works of nature-the tangible evidences of a good and great Creator-deserving of a higher position than that of a mere toy? I think so; and in order to study them aright we must bring our heart to the work, determining that whatever we accomplish we may accomplish well; and in order to do this we must do all things in their appointed time, not leaving that tili to-morrow that ought to be done to-day, or doing that in the night to which the hours of the day ought to be legitimately devoted; thus neglecting our business, on the successful prosecution of which our worldly comfort bangs. I will relate an anecdote in point.

Samuel Drew, M.A., was born of poor parents, in the parish of St. Austell, Cornwall, March 3rd, 1765, and at the age of ten years was apprenticed to a shoemaker at St. Blazey. 'The following trifling circumstance laid the foundation of his future greatness. He says: "When I began business I was a great politician. My master's shop had been a chosen place for political discussion, and there, I suppose, I acquired my fondness for such debates. For the first year I had too much to do, and to think about, to indulge my propensity for politics, but after getting a little a-head in the world I began to dip into those matters again; very soon I entered into newspaper arguments 
as deeply as if my livelihood depended upon it. My shop was often filled with loungers who came to converse upon public measures, and now and then I went into my neighbour's houses upon a similar errand. This encroached on my time, and I found it necessary sometimes to work until midnight to make up for the hours I had lost.

"One night, after my shutters were closed, and I was busily employed, some little urchin, who was passing the street, put his mouth to the keylole of the door, and with a shrill pipe cried out, 'Shoemaker! Shoemaker! work by night and run about by day!' Had a pistol been fired off at my ear I could not have been more dismayed or confounded; I dropped my work, saying to myself, 'True, true! but you shall never have that to say of me again!' I have never forgotten it; and, while I recollect anything I never shall. To me it was the voice of God, and it has been a word in season throughout my life. I learned from it not to leave till to-morrow the work of to-day, or to idle when I ought to be working. From that time I turned over' a new leaf.

"Thanks, a thousand times thanks, for that piece of midnight mischief!"

Now the working man in his prosecution of the science of Entomology need not, ought not, to neglect his business for it, but if he takes up its study he ought to prosecute it vigorously (not by fits and starts), determining to know all he can respecting the objects of his study, and not rest satisfied with being a mere collector of species, but aim at becoming a naturalist, not in name only but in deed; and this is quite within 
the compass of a working man's powers, if he be only of an energetic spirit. Take, for instance, the case of Ralph Finley, the shoemaker Entomologist, who died in 1789. Lackington mentions him as "one who had not dignity of birth or elevated rank in life to boast of, but who possessed what is far superior to eitlier - a solid understanding, amiable manner's, a due sense of religion, and an industrious disposition. Amongst other acquisitions Entomology was his peculiar delight; his valuable cabinet of insects, both foreign and domestic, all scientifically arranged with peculiar neatness and in the finest preservation, is supposed to be the finest private collection in the kingdom, and will remain a monument of his application and knowledge." "Go thou and do likewise."

"Lives of great men all remind us, We may make our lives sublime;

And, departing, leave behind us

Footprints in the sands of time-

Footprints, which, perhaps another, Sailing o'er life's solemn main-

Some forlorn and shipwreck'd brother-

Seeing, may take heart again."

And now, on this balmy April morn, let us bid adieu for a while to that huge mass of brick and mortar, London--beautiful as a city, though it be, like ancient Rome, "Mistress of the Nations" - and betake ourselves to the open country, more beautiful still as it glows in the sunlight, clothed in verdure of richest green;-and whither shall we bend our steps-where but to the famous "Black Fence" on Dartford Heath, 
celebrated for "Pictaria," and from thence we will extend our journey to Birch Wood.

Having obtained our tickets for the Dartford Station of the North Kent Railway, and ensconced our'selves in our seats, we shall in due time arrive there, when, if we direct our course across the Heath, leaving "Darn" on our left, we shall soon arrive at our destination-the Black Fence surrounding Baldwyns, the estate of Mrs. Mennett: and truly it is justly celebrated; for if a smart gale from the south-west blows, the fence is literally swarming with insects which, as Mr. Stainton observes, the collector has nothing to do but box-he hardly needs to look for them. I have been on Dartford Heath at three o'clock in the morning in the month of June, when a brisk south-wester has been blowing, and have seen the moths making direct for the fence, which many of them never reached, being intercepted by the net. Dartford Heath is a flat, sandy, elevated plain covered with heath (Erica cinerea), and has a very wild and comfortless appearance. A tyro, unacquainted with the peculiarities of the place, would at once pronounce judgment against it (if he were prone to jump at conclusions); but he must not judge by appearances in respect to Entomological localities; if he does, he will often be deceived, the most out of the way and uninviting situations often producing the greatest har'vest to the collector, and such a one is "Dartford Heath."

Now let us commence our examination of this peculiar locality; and first we will commence with the fence: on looking at it carefully we shall find the larvæ of Taleporia pseudo-bombycella and Xysmatodoma 
melanella wandering about in their cases, while among the dead leaves accumulated in the hollow at the bottom of the palings we shall find the pupæ of Incurvaria muscalella; and in the stems of the rough cock's-foot grass (Dactylis glomerata), mining down towards the root, we may find the white wiry larvæ of Ochsenheimeria Birdella.

On the fungi on the palings the pupæ of Tinea parasitella will be found; while in the shoots of the ash the larva of Prays Curtisellus occurs, feeding on the unexpanded leaves: on the palings we shall find the curious semi-transparent Solenobia inconspicuella, and by looking very closely we may perhaps detect the curious vermiform females of the same species. This is one of the few species of Lepidoptera in which alternation of generation occurs, unimpregnated females laying fertile eggs. But what is that pale grey insect on the palings among the fir trees? that is Ocnerostoma piniariella; while on the larches over our heads we shall find the larvæ of Coleophora Laricella, and on the palings we shall see, among the birches, Semioscopis Avellanella, and in the neighbourhood of the sloe, Semioscopis Steinkelneriana occurs. But oh! whatever is this dingy black, plain-looking insect? "O fortunate puer!" you are a lucky man; that is the very rare and puzzling Aleucis pictaria, occurring only on this fence in April, and been once taken at Colchester, where several came to light in a room. Having been so lucky as to find pictaria, you might rest satisfied, but continue your search and it may be rewarded with Zelleria insignipennella. 
And now having got to the end of the paling, let us make a short excursion to Birch Wood. Birch Wood lies on the direct Maidstone Road, near the "Bull" Inn, and will be easily found from Dartford Heath; Dartford Heath lying in the centre between Birch and Darenth ("Darn") Woods, the latter lying to the left.

It is a magnificent wood, full of fine old noble trees, and having a thickness and diversity of underwood truly surprising, while the herbaceous plants cover every foot of open ground, and, sheltered among the underwood, afford a fine cover and food for numberless insects.

And now we will put the sweeping net into requisition; and first we will operate upon those birches. Take the net by its handle in your right hand, and gently but briskly sweep it over their twigs; having operated thus upon several trees, we will examine the contents of the net, and laying it down upon the ground, we commence carefully to turn it partially inside out, bringing a portion of the rubbish at the bottom to the side: now gently blow it in order to get rid of the dust and dead leaves as much as possible. See! what is that pretty little purple insect so thickly sprinkled with golden spots? That is the beautiful little Micropteryx Sparmannella, while by its side, trying to make its escape from the debris, is the pretty little Micropteryx unimaculella, with its delicate purple wings in which is a single white spot, together with Micropteryx purpurella and semipurpurella.

While (at West Wickham) Micropteryx Salopiella occurs on birch, and may be obtained by sweeping the 
twigs; calm sunny afternoons are the best suited for this operation.

But look, what is that large insect on the birch stcm near that pool of water? lucky again, that is Notodonta Carmelita (this insect also occurs at West Wickham on the "Bishop's palings"). And now having " bagged" your game persevere in your search, for here the unique Solenobia Douglasii was taken.

And now lct us beat the oaks for a little while, and see what they produce. Click goes the beating-stick among the branches. Hilloa! what are you? Oh! only Tortricodes Hyemana; get out, you common rascal! I can take you any time. Stop my fricnd; do you want the insect? Yes! Then take it; don't put off till to-morrow what, can be done to-day; if you don't take it now, perhaps you will not get another chance till next season, and your check will be incompletc of a common insect. I believe many cabinets are thus incomplete from the prevailing idea that common insects can be taken "any time," and therefore are to be left till the last, so that the collector frequently comes home with a fcw insects that he fancies he "does want" that are not common, leaving behind him many insects that are strangers to his cabinet because they are "common."

By beating you will obtain from among the oaks Heusimene fimbriana and Dasystoma Salicella; while on the trunks of the oak trees ncar the roots Biston prodromaria may be found, together with Chimabacche fagella, male and female, and among the birches, flying by day, Incurvaria pectinea occurs.

In cases among the "wind flower" or "Wood D 5 
Anemone" (Anemone nemorosa) the larvæ of Adela Degeerella occur; and among broom, between united twigs, the brown larvæ of Depressaria assimilella may be found.

On the hedge banks, in rolled up grass leaves, the handsome larva of Gelechia rufescens is still feeding; while in a burrow near the root of the sorrel (Rumex Acetosa), the larva of Gelechia diffinis may be found, and in the flowers of the furze, entering them at the back, the larvæ of Gelechia mulinella find a home. In the young shoots of the "greater stitchwort" (Stellaria holostea), the larvæ of Gelechia tricolorella may be found agglutinating the shoots, while in the shoots of the "bog stitchwort" and the broad-leaved mouse-ear chickweed (Cerastium vulgatum), the sluggish brown larvæ of Gelechia fraternella may be found twisting and agglutinating them in various ways. If we look at the leaves of the kidney vetch or lady's finger (Anthyllis vulneraria), we shall observe the leaves mined in white blotches; these, at first sight, have the appearance of being the work of Dipterous larvæ; but on opening one or two of them we shall find them inhabited by a dark brown larva with a little white at the back of the head; this is the larva of Gelechia Anthyllidella. In the seeds of the burdock (Arctium Lappa), we shall find the larvæ of Parasia Lappella; while in the yellow hoary mullein (Verbascum pulverulentum), the larva of Nothris Verbascella occurs. On the leaves of Chenopodium and Atriplex, under a loose web, we may find the larva of Butalis Chenopodiella; while on the underside of the leaves of the "dames violet" (Hesperis matronalis), 
the larva of the pretty Plutella porrectella occurs; the larva of this species forms a beautiful open network cocoon on the underside of the leaves of the plant on which it fed, in which it changes to the pupæ state; it also occurs in gardens feeding on the common "rocket."

In the shoots of the "stone-crop" (Sedum acre), "growing on a barn at Bexley," the larva of Glyphipteryx equitella occurs; while in the shoots of the birch, and also under the bark, the larvæ of Argyresthia Goedartella and $A$. Brockeella will be found.

If we look attentively at the leaves of the "ribwor't plantain" (Plantago lanceolata), we shall see on the front of many of them a dark brown line running up the centre; this is the mine of the young larvæ of Gracilaria tringipennella; when nearly full fed the leaf is considerably hollowed out in the mined abode, which becomes broader, but the back of the leaf never becomes discoloured; the pupa is enclosed in a white cocoon within the mine.

On the Hypericum perforatum Messrs. Gracilaria auroguttella \& Co. still submit their genuine "cigars" to the collector's notice, who will do well to lay in a stock, as the establishment "positively closes this month." While mining the leaves of the thorny restharrow (Ononis spinosa), and the dyer's greenweed (Genista tinctoria) the larvæ of Gracilaria Ononidis may be found.

If, in places having a south or south-western aspect, we examine the young leaves of the "black knapweed" (Centaurea nigra), we shall observe that many of them, some actually laying flat upon the ground, are 
marked with large white blotches; if we turn over the leares thus marked we shall see upon some of them a long black case containing a larra; this is the larva of Coleophora Alcyonipennella. Now let us examine that pretty plant with yellow papilionaceous blossoms; this is the bird's-foot trefoil (Lotus corniculatus); if we search the leaves we shall see that many of them are wholly white, and some have white blotches on them; these are caused by the larra of Coleophora. discordella, and on turning over the white or blotched leaves we shall find him in his cornucopia-shaped case. I took this larra by hundreds in the vicinity of Dublin, in company with that of $C$. Alcyonipennella, the latter not nearly so abundant.

On old palings and trunks of trees we shall probably find the pupre of Coleophora paripennella; while in wet marshy places the larva of Col. caspititiella occurs upon the heads of rushes; while in the leaves of the reed meadow-grass (Poa aquatica), making very long narrow mines, the larræ of Elachista Poa may be found; and in the leares of the rough-stalked meadow grass (Poa trivialis) we may see the larva of Elachista nigrella in its mined abode.

If, in barren sandy places, we examine the leares of the "bugloss" (Echium vulgare), we may find the larræ of Coleophora Onosmella; and on the "black fetid horehound" (Ballota nigra), and the hedge wound-wort (Stachys syliatica), the larve of Col. lineolea occur ; while, in the roots of the latter plant, we shall, perhaps, find the larræ of Orthotania antiquana.

On the leares of the wild rose we shall find the larve 
of Col. gryphipennella; and on the leaves of sallows and osiers the larvo of Col. Viminetella oceur.

On the hedge bank, in the leaves of the rough cocksfoot grass (Dactylis glomerata), mining fiom the points downwards, we shall find the pale larves of Jiachista cygniponnella; while in the arrgles of the leaves of Holcus mollis, and on other neighbouring plants, the pupe of Elarhista rufocinerea will be found; and, mining in the ledves of Brachypodium sylvaticum and Bromus assper we shall find the larvo of Elachista Megerlella in plenty.

Mining in the leaves of the common sun cistus (Helianthemum vulgare) we shall find the larve of Sarerna Staintoni; ard, in the leaves of Bromus erectus the larva of Elachista subrigrella occurs; while in the young shoots of the spindle (Euorymus Europaus) we shall fird the yourg larvas of Hyponomeuta plumbellus focoling on the pith, thus causing thern to droop; Theristis caudella also oceurs amonre Euorymus.s.

In the leaves of the carline thistle (Carlina vulgaris), mining the upper side of the young leaves, the larva of Depressaria manatella occurs (at Jox Hill and near Torquay, Jevon); while between the united leaves of hawthorn the larvas of Gicl. vulgella may be found, and in the leaves of Molcus mollis we shall probably fird the larve: of Elarlixto albifrontella; while in the leaves of a carex (rear Beckenharn) the larva of the beautiful Elachista Cileirhenella occurs, making white blotches in the ledves, and moving readily from one leaf to ariother.

In the leaves of the evergreen oak (Quercus Ilex) 
the larvæ of Lithocolletis Messaniella will be found; while mining the underside of the leaves of the honeysuckle we may discover the larvæ of $L$. trifasciella, and in places where Scabiosa columbaria grows (Headly Lane and Croydon) we shall find the larvæ of Lithocolletis Scabiosella; while, mining beneath the bark of broom the curious larvæ of Cemiostoma spartifoliella will be found; and in the leaves of the brambles the larvæ of Nepticula aurella still traverse their subcutaneous galleries.

In the evening, flying along hedges, we shall see the resuscitated specimens of the autumn brood of $D e$ pressarice liturella, arenella, Alstrcemeriana, purmurea, ocellana, applana and Heracliana; these also occur at sugar, and frequent the sallow blossoms at right, together with the following early Noctua:Treniocampa instabilis, gracilis, munda, sparsa, pallida, stabilis and gothica. These should be searched for at night by the light of a lantern, sweeping the branches with a net; some good larvæ may also be found by searching the young buds of the birch, with a lantern, at night, viz. : the larvæ of Tryphena fimbria and Aplecta tincta. At night we may obtain Clostera curtula and Demas Coryli; while at sugar, and by beating, the following species may be obtained: Xylocampa Lithoriza, Ceropacha ridens, Phlogophora meticulosa, Cucullia Verbasci, Plusia Gamma, Biston hirtarius, Odontopera bidentaria, Rumia Cratagaria, Coremia fluctuaria, Ennomos illustraria and Eupithecia rufifasciaria. While on the heather' the handsome Saturnia Carpini may be found, together with the beautiful green larvæ of the active and 
attractive Anarta Myrtilli. In gardens, upon sunny days, we may see the curious humming-bird hawkmoth (Macroglossa Stellatarum) hovering over the flowers, while the early Papilios, Pieris Rape and Brassicre, dodge about among the cluciferæe on mischief' bent.

On grassy banks the brilliant little Chrysophanus Plulcas glitters like polished copper in the sun; and at Birch Wood the uncommon Endromis versicolor occurs.

On sandy heaths the active Gelechia velocella occurs; while in the New Forest, on the trunks of the trees, is the habitat of Gel. humeralis; and on moors in the north of England Butalis incongruella may be found; while in the hedges, among the woody nightshade (Solanum dulcamara) we shall find the pretty Acrolepia pygmeana flying freely on sunny afternoons; and, among the sallow blossoms, flying in the sunshine, the rare Adela cuprella occurs, together with worn specimens of Gracilaria stigmatella.

Among alders the rare Gracilaria falconipennella occurs, while in the hedges Swammerdamia apicella and Pyrella, together with Ornix Anglicella and Laverna decorella, occur.

In the New Forest may be found, among heathel and oaks, Coriscium Sulphurellum and C. Brongniardellum; together with $C$. cuculipennellum among privet.

On palings, and by beating fir trees, and among wild apple trees, Lyonetia Clerchellu occurs; while among poplars we shall find, most probably, the beautiful Phyllocnistis suffusella, and, among willows, P. Sa- 
ligna; these may also be obtained by beating ivy. While on palings, among brambles, the handsome N. Aurella will be found; and among orpine (Sedum telephium) the rare and distinct Hyponomeuta vigintipunctatus occurs.

In houses Tinea pellionella and biselliella and Endrosis fenestrella may be found "at home" as usual.

If we examine the stems of the common reed (Arundo Phragmites) we shall find in them the larvæ of Chilo Phragmitellus; while in the stcms of the reed meadow-grass (Poa aquatica) the larva of Chilo forficellus is still feeding; in moss, in silken galleries, we shall find the larvæ of Crambus falsellus and Cr. tristellus; and in the stems of thistles the larva of Myelois cribrum occurs.

Among seeds we shall find the larvæ of Tinea fuscipunctella and Endrosis fenestrella; while, snugly ensconced amid the careful housewife's stores of clothes, furs, feathers, \&c., the larvæ of Tinea Pellionella and biselliella "cry havoc and let loose the dogs of war."

In cases among wild strawberry (Fragaria vesca), on the underside of the leaves, the larva of Lampronia prelatella occurs; and in the shoots of raspberry bushes the larvæ of Lampronia Rubiella may be found; while, feeding on the pith in the young shoots of currant bushes, the larvæ of Incurvaria capitella works unseen; and under the lcaves and on the flowers of the coltsfoot (Tussilago furfara), the hairy larva of Pterophorus trigonodactylus will be found; while, fceding in moist decayed wood, the larva of AEcophora unitella occurs.

And now for the benefit of the tyro who, in the ardent 
pursuit of Entomology, may often find a rarity that older hands may miss, I will transcribe the natural history of the larva of that beautiful and extremely rare moth "The Essex Emerald" (Phorodesma Smaragdaria), translated by that active and energetic Entomologist, J. W. Douglas, Esq., from the Stettin "Entomologische Zeitung," and read by him before the Entomological Society of London, March 1st, 1852.

"The larva of Phorodesma Smaragdaria (Esper), by G. Koch, sen., Frankfort-on-the-Maine."

"Hitherto this larva and its natural history have been entirely unknown; neither Ochsenheimer', Treitschke, nor any other author, has given any account of it, for if they had, the perfect insect would probably not be such a rarity. The moth flies in woods late in the evening; on which account it is seldom taken; and the larvæ are so deceptive to the eye that they have hitherto eluded all search for them. The merit of solving the riddle belongs to Herr Verwalter Mühlig, who succeeded in finding an impregnated female which laid eggs, by which circumstance we were put upon the search, and now we find the species not uncommonly in our town woods. I give the following account with this remark, that, although it is made exactly after nature, everything is not to be found therein which may be observed with a lens in these most remarkable larvæ. Besides, the matter is sufficiently interesting to render it desirable to be acquainted with the details of the natural history of these larvæ, otherwise than in fragments as at present, and to learn some particulars about their early states. 
"As soon as the larva leaves the egg, it loads its body with finely bitten pieces of stems of plants, scales of flowers, hard, dry seed capsules and other small vegetable fragments, which it binds together strongly, although loosely, and in layers, and forms into a mass full of points and projections (requiring much trouble to pull to pieces with pincers), the whole of which it carries about with it like the allied larva of Phorodesma Bajularia. This covering is, however, very different from the cases of the Psychida. The larvæ enlarge these coverings according to their requirements, and as they hybernate in them when very small, it is not easy to rear them from that state. The warmth of Spring entices them out to the plant on which they feed - the milfoil (Achillea millefolium). When reared in confinement, however, they will feed upon Poterium Sanguisorba. The head of the larva is small, and the fore part of the body is also slender; the hinder part is crossed all over with deep wrinkles and corresponding elevations. Beyond the first segment the body is flattened on each side. On the back stand four elevations or humps, each terminated by a sickle-shaped hair; a smaller hump stands on each side of the large black spiracle; these six humps, each on a distinct segment, are separated by long furrows; the remaining space is covered witl innumerable little warts, which make the larva feel rough to the touchviewed with a lens these look like the deep-cleft bark of oak trees. All the remaining segments are covered with these elevations, points, humps and furrows, to which, as may very easily be observed, the. little bits of plants are fastened in layers of small bundles. The larva is earth-brown; a long darker line is on the 
middle of the back, and three, more or less clear, long streaks on each side. It attains eventually the length of a Paris inch, but sits always in a contracted position, and this, added to the unyielding nature of its case, gives it a most deceptive resemblance to a hard seed capsule or a little mass of flower's.

"When about to go into the pupa state, it seeks a hard flower-stalk, on the top of which, or sometimes only high up thereon, it makes fast fragments of flowers in the form of an open-work case, in which, in about a day, it changes to a pupa, and within three (seldom four) weeks it appears in the perfect state.

"Light places in woods, plains and dry ditches in woods, where the plants grow on which they feed, are the favourite localities of these caterpillar's. When once one is discovered, several more may certainly be found in that neighbourhood. The best season to seek them is from the beginning to the middle of June, when they have become full fed, and are approaching their transformation. For this purpose it is not necessary to use much apparatus, for if care be not taken they are very easily deprived of their artistic coverings."

And now I have only to repeat that which I mentioned at the commencement of this chapter-Never put off till to-morrow the work of to-day; but make each day do its own work: for-

"He who trusteth to the morrow

Soweth gold and reapeth sorrow." 


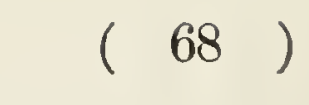

CHAPTER V.

M A Y.

"Oh! charming May; oh! charming May;

Fresh, fair; fair and gay:

That com'st from thy bowers,

'Mid perfume and flowers,

Charming, charming, charming May.

Thou art spring with its winter's days gone by,

And summer without its scorching sky;

The sun may be bright, the storm may be free,

But the tranquil beauty of May for me."

"Oh! charming May; oh! charming May;

Fresh, fair; fair and gay:

That com'st from thy bowers,

'Mid perfume and flowers,

Charming, charming, charming May.

'There is gladness and joy in thy genial face,

Fit emblem of innocence, freshness and grace;

There is peaceful delight, to me ever dear,

In charming May, the green month of the year."

The season has now commenced in earnest. The insect tribes are now in full vigour, each on its mission bent, whether as larvæ devouring the young shoot or mining the yet imperfectly developed leaf, or as the perfect insect flitting about in the bright sunshine, or sporting in the balmy air of the soft May evening by the light of the "Ladye Moon." 
But not alone do the insect tribes feel the influence of "the season;" its effects are plainly felt by the bipedal inhabitants of this sublunary planet. Winter' clothing begins to be "offered at an alarming sacrifice, in order to make room for the summer stock." Waterproof alpacas have fallen to an alarming discount; parasols of mushroom dimensions and elaborate workmanship take the place of the umbrellas in the shop windows. The confectioner seriously thinks of exposing to the public gaze the glass label, which has lain so snugly beneath his counter throughout the winter, on which is inscribed the single word "Ices." Perambulating ginger-beer establishments may now be met with at the strect corners. The metropolitan watercarts now distribute their aqueous contents over the dusty roads and the polished boots of the unwary pedestrian. Exeter Hall opens its portals to the "thousand and one" societies that annually hold their meetings within its walls; while at the "Royal Academy" the "Portrait of a Gentleman" may be stared out of countenance, if possible, for " the small charge of one shilling." In fact the season has commenced-London has begun to fill with people and the country with insects. The country now presents a charming aspect. The fully expanded bud displays itself in all its charms, clothing the hedges in a garb of refreshing green; the hawthorn now is in full bloom, filling the air with a delicious fragrance, and the slender shoots of the honeysuckle clasp its stems, or hang gracefully from the branches, exposing to the sight its cluster's of beautiful flowers; while the frisky lambs and full-uddered cows, as they lay in the green meadows quietly chew- 
ing the cud or cropping the fresh green herbage at their feet, awaken those feelings of peace and tranquillity so welcome to the contemplative mind :-

"Neglected now the early daisy lies;

Nor thou, pale primrose, bloom'st the only prize!

Advancing Spring profusely spreads abroad

Flow'rs of all hues with sweetest fragrance stor'd:

Where'er she treads, Love gladdens every plain,

Delight on tiptoe bears her lucid train:

Sweet hope with conscious brow before her flies, Anticipating wealth from summer skies;

All nature feels her renovating sway!

The sheep-fed pasture, and the meadow gay,

And trees, and shrubs, no longer budding seen,

Display the new-grown branch of lighter green;

On airy downs the idling shepherd lies,

And sees to-morrow in the marbled skies.

"Say ye that know, ye who have felt and seen

Spring's morning smiles and soul enliv'ning green,

Say did you give the thrilling transport sway?

Did your eye brighten, when young lambs at play

Leap'd o'er your path with animated pride,

Or gazed in merry clusters by your side?

Ye who can smile, to wisdom no disgrace,

At the arch meaning of a kitten's face;

If spotless innocence and infant mirth,

Excites to praise, or gives reflection birth,

In shades like these pursue your favourite joy,

'Midst nature's revels-sports that never cloy."

Bloomfield's Farmer's Boy (Spring).

And now, courteous reader, let us "pursue our favourite joy;" and to this end we will journey to Wimbledon Common, and thence to Coombe Wood, the favourite hunting-ground of the late J. F. Stephens, Esq. 
Having obtained our tickets at the Waterloo station of the South Western Railway for the Wimbledon station, we shall, after about half an hour's riding, arrive there, when, in order to reach the common, we must cross the railway bridge and keep straight along the road and through the town; this will bring us on to the common near Wimbledor Park. But if, instead of keeping by the park side, we bear to the left, we shall soon arrive at the "windmill" upon the common, and be at once in good collecting-ground. The ground is covered with a great quantity of scrubby sallow and oak, small birch trees, furze, broom, willow, heather, fer'n, and a great variety of herbaceous plants. On the edge of the common, towards the lane leading. to the "Stag," are a number of good aspens (Populus tremula), while at the southern side of the common is situated "Coomb Wood." This is a fine wood, containing a great number of trees of good growth, besides underwood and a fine broomfield.

And now let us search for our pets : and in the first place the sallows invite our notice. In their shoots we shall find the larvæ of Depressaria conterminella, while in their rolled leaves and in those of the neighbouring birches, as well as in poplars, the larvæ of Gelechia populella will be found. If we search the shoots of the broom (Spartium scoparium), we shall find between united twigs a brown larva with dark tubercles; this is the larva of Depressaria Atomella: while in the broom flower's, as well as in those of the furze (Ulex Europceus), the larvæ of Gelechia mulinella occur, and in the heads of the St. John's wort, in the dry spots, the larvæ of Depressaria $H y$ - 
pericella may be found. Under the leaves of the oak, in a web, the pretty larva of Phibalocera Quercana will be found (in Ireland it feeds commonly on the arbutus); while on the honeysuckle the larvæ of $\mathrm{Ce}$ rostoma vittella, nemorella and Xylostella will be found: on sallows the larva of Gelechia sororculella occurs; and in the terminal shoots of Artemisia campestris(?) we may, perhaps, find the larvæ of Gel. Artemisiella. Herr Schmid says "Larvæ in May on thyme (Thymus Serpyllum) between united leaves""a more likely food-plant than Artemisia." - (Entomologist's Annual, 1856, pp. 51, 52.)

In the stems of the "rough cock's foot grass" (Dactylis glomerata), near the root, the white wiry larva of Ochsenheimeria Birdella may be found, while in the rolled-up leaves of this and other grasses the larva of Gelechia rufescens occurs.

On the underside of the leaves of the wild rose we shall find the larva of Coleophora gryphipennella making white blotches on the leaves, and the larva of Lampronia quadripunctella occurs on the same plant; while in the young shoots of the sweet briar (Rosa spinosissima) the larva of Spilonota roborana may be found, and in the shoots of whitethorn the larva of Spilonota suffusana occurs; on this plant also may be found the larvæ of Gelechia vulgella between united leaves.

In the shoots of sloe (Prunus spinosa), feeding upon the young heart leaves, the larvæ of Argyresthia albistria and mendica occur, while in the shoots of the whitethorn the larvæ of Argyresthia nitidella may be found feasting upon a similar dainty pabulum. But 
what is that plant with white starry blossoms that so profusely clothes that dry bank? that is the "broad leaved mouse-ear chickweed" (Cerastium vulgatum), in the shoots of which as well as in those of the "bog stitchwort" (Stellaria uliginosa), the larva of Gelechia fraternella may be found in plenty; while in the shoots of the "greater stitchwort" (Stellaria holostea), which you see trailing along the bank or climbing the hedge, the larva of Gelechia tricolorella may be found, while on its leaves, making long whitish blotches, the larva of Coleophora solitariella occurs, while the larva of Gelechia maculea feeds upon its shoots and seeds.

On the shoots of Atriplex, growing on that waste patch of ground, the larvæ of Gelechia Atriplicella may be found, and in its stems, as well as in those of the goosefoot (Chenopodium), the larva of Gelechia obsoletella occul'; while on sloe, hawthorn and apple the larva of Hyponomeuta Padellus carry on the work of defoliation in concert; and between the united leaves of apple (or hawthorn) we shall find the larvæ of Gelechia leucatella; while in the shoots of the furze (Ulex Europcens) the larva of Anarsia Spartiella occurs.

Now let us see what this wet spot, nicely sheltered by the overhanging aspens, will produce us. What is that tall plant, with the long willow-like leaf? that is the "great hairy willow herb" (Epilobium hirsutum); in the lower lcaves of this we may find the pupæ of the pretty Laverna ochraceella, while on the neighbouring sallows and osiers the larvæ of Coleophora viminetella may be found; and on poplars and willows, between 
united leaves, the larvæ of Batrachedra praangusta occur. On the old heads of the rushes the larva of Colcophora crespititiella occur's; while on the leaves of Eupatoria cannabinum and Inula dysenterica the larvæ of Coleophora troglodytella may be found; and the larvæ of Orthotclia Sparganella burrowing in the leaves of the "burr reed" (Sparganium).

On the leaves of the "cow parsley" (Chcerophyllum) the larva of Depressaria Weirella occurs; and, mining in the leaves of the "rib-wort plantain" (Plantago lanceolata), we shall find the larvæ of Gracilaria tringipennella.

On elm, alder', hornbeam and nut, the larvæ of $\mathrm{Co}$ leophora fuscedinella occur; $C$. palliatclla and $C$. anatipennella on oak, birch, sloe, \&c.; C. currucipennella on oaks; C.lutipennella on oaks and birches; C. nigricella on hawthorn, sloe, birch, \&c.; and C. badiipennella on elm and ash. While, feeding on the shoots of the heather, the larvæ of $C$. pyrrhulipennella may be found.

In tubularly rolled leaves of honeysuckle we shall find the larvæ of Gelechia Mouffetella; while in the shoots of the "common sun cistus" (Helianthemum vulgare) the larva of Gelechia sequax occurs.

On the "yellow hoary mullein" (Verbascum pulverulentum) the larvæ of Nothris Verbascella may be found ; while on the "gout-weed" (Egopodium podagraria) we may, perhaps, meet with the larvæ of Chauliodus Illigerella; damp places in woods are the most likely spots to search for them.

In gardens and orchards, feeding on the blossoms of the pear, we shall find the larvæ of Gelechia nanella; 
while on the leaves of the same tree the larvæ of $\mathrm{Co}$ leophora hemerobiella occur, and those of Argyresthia ephippella in the shoots of cherry; Cerostoma scabrella on apple trees, together with that of Gel. Rhombella. On the "black fetid horehound" (Ballota nigra) and the "hedge wound wort" (Stachys sylvatica) we may find the larvæ of Coleophora lineolea; while the larva of Col. Alcyonipennella occurs on the leaves of Centaurea nigra. And in folded birch leaves we shall find the larvæ of Poedisca Solandriana (in Wimbledon Park); this larva prefers the scrubby low-growing birch bushes to tall trees.

On the "goose-foot" (Chenopodium) and the orache (Atriplex), under a loose web, we may find the larvæ of Butalis Chenopodiella; while on sallows the larva. of Gelechia sororculella occurs.

And now, having spent some considerable time upon the common (which swarms with insect life) let us visit

"The wood,

The covert of old trees with trunks all hoar,

But light leaves young as joy .....

A populous solitude of bees and birds,

And fairy-formed and many-colour'd things."

ByвоN-Childe Harold.

On our way to Coombe Wood we pass the aspens at the edge of the common; if we examine their stems we shall probably find Clostera reclusa sitting on them; the larva of this insect is common on them, and on the sallows in September.

Having reached the wood let us commence operations. What is that large pale-coloured moth sitting E 2 
on the trunk of that tree? that is the "Miller" (Apatela Leporina); while on the trunks of the trees, among the lichen, we shall find the once-seen-never-tobe-forgotten Lithosia rubricollis (the red-necked footman). Let us now try the birches, by beating them carefully over the net; gently does it! what have you now? Ephyra pendularia and poraria, and a fine specimen of Platypteryx Lacertula; a good beginning. If we search those alders we shall find $Y$ psipetes impluviaria, while among the spurge (Euphorbia) we may obtain the plain little Minoa Euphorbiaria. Among the sallows Cabera pusaria and exanthemaria occur; while Cabera rotundaria may, perhaps, be met with in the same situations.

But the moths on the tree trunks, and settled among the leaves, are not the only denizens of the wood of this order; on its skirts the pretty Anthocaris Cardamines flits along, while in the shady paths Leucophasia Sinapis and Nemeobia Lucina may be met with ; and in the open glades the beautiful Melitaa Athalia may be found, together with the equally handsome Argynnis Selene and Euphrosyne; in the meadows, on the outskirts of the wood, the active "skippers" Syricthus alveolus and Thanaos Tages occur.

On grassy banks and meadows the "blues" Polyommatus Argiolus and Alexis occur, and in chalky places (Riddlesdown) Polyommatus Adonis may be found ; while in woody places, on the chalk, Polyommatus Acis occurs, and in meadows, usually in Suffolk, Melitca Artemis may be found. Among ragwort (Senecio Jacobea) we shall find Euchelia Jacobece; together with the beautiful Argyrolepia Aneana, on 
the banks of the Paddington Canal, near Old Oak bridge.

In order to obtain this latter insect (Argyrolepia Eneana) the tyro has no occasion to use a net either for sweeping or beating, but only to furnish himself with a good supply of pill boxes. Having arrived at his hunting-ground a little before dusk some evening, in the latter end of May, let him narrowly watch the bottom of the clumps of ragwort, and the tufts of grass and herbage surrounding them; as soon as it is dusk he will see the insects come out from among the roots and herbage, in order to commence their evening excursion, and as they successively make their appearance all he has to do is to box them; they are by no means active in their movements, keeping very close to the ground, flying but a short distance at a time, and alighting upon blades of grass, the leaves of the ragwort, and upon the ground; so that with a little care they are very easily taken.

In the moist places in woods, among bugles, Sesia Bombyliformis and S. fuciformis occur; while Trochilium Cynipiforme is only to be obtained in Hyde Park. Among the willows Smerinthus Ocellatus and Tilia occur, together with Clostera curtula; and in the evening, on grassy banks, we shall see the pretty Hepialus lupulimus practising his rapid and eccentric flight.

In the wet places we shall find the conspicuous Pliragmatobia mendica and $P$. menthrasti; while on tree trunks and palings, among Lychnis dioica, we may perhaps find Cloantha conspicillaris. On garden palings we shall find Hadena oleracea and H. Bras- 
sica, together with Coremia fuctuaria; while among brambles Acronycta Rumicis occurs; and at sugar, in places where Myrica gale and Salix caprea grows we may perhaps capture the pretty Acronycta $M y$ rice (Euphorbia), "from May 27th to June 15th, at rest on rocks in open moors." Mr. Weaver, in the Zoologist for 1846, p. 1439.

Among birches we shall find Ephyra punctaria, Coremia ferrugaria, Tephrosia crepuscularia, and punctularia; while, sitting upon the tops of posts or on palings, Cucullia Scrophularice may be found.

Harpalyce Achatinaria occurs plentifully on the common and in the wood, and Hemerophila abruptaria on palings and walls; while Tephrosia consonaria occurs at "Black Park," Bucks; Abraxas Ulmaria among beeches in most districts; Pieris Daplidice should be sought for at Dover, and Papilio Machaon in the fens; with Vanessa Io and Satyrus Megara everywhere.

Among broom (Spartium scoparium) Speranza conspicuaria occurs near Stowmarket; and in woody lanes, Venilia macularia and the curious Cilix spinula may be found, together with Chesias obliquaria and Dosithea reversaria; while in the wood, among birch trees, Platypteryx falcula and Hamula occur.

On the Downs at Croydon we shall find Pyrausta purpuralis, and at Purley, among spruce firs, Coccy $x$ Strobilana; in weedy lanes, among nettles, Botys $U r$ ticalis will be found; and in gardens and lanes Pionea forficalis, and, in woody places, Polypogon barbalis occurs; and on grassy banks, among flowers, Anchylopera Lundana occurs, "flying from half-past five to 
six in the morning," and Dicrorampha Petiverana among tansy (Tanacetum vulgare).

Under the bark of lime trees we shall find the larva of Chrysoclista Linneella, and from beneath the bark of the birch we shall obtain the pupæ of Argyresthia Goedartella and Brockeella; while mining in the leaves of the "chickweed-leaved willow-herb" (Epilobium alsinifolium), near Renfrew and Fochabers in Scotland (and at "Darn ?"), we shall find the larvæ of Chrysoclista Schrankella.

In the house, among seeds, woollen clothes, furs, hair, feathers, \&c., we shall find the larvæ of Tinea tapetzella, pellionella and biselliella, together with the larva of the ever-present-never-to-be-forgotten Endrosis fenestrella.

On the common Cromwell (Lithospermum officinale), and the lungwort (Pulmonaria), we may find the larva of Anesychia pusiella, and in rotten wood the larva of Ecophora unitella.

In pod-like galls upon the buds of Polygonum aviculare, in sandy places, we may find the pupæ of Asychna cratella; while feeding on the young shoots of the heather, in a small case resembling small heath leaves, the larva of Coleophora juncicolella may be found at West Wickham, and the larva of Coleophora Wockeella upon Betonica and Ranunculus. Herr Schmid says, "larvæ at the beginning of June on Stachys hirta, preferring the stems to the leaves;" and Professor Frey observes, " not scarce on Betonica and Ranunculus in April and May.' -Entomologist's Annual, 1856, p. 55. 
And now let us sit down on this grassy bank and see what the rank vegetation will afford us on a careful search. Mining in the leaves of the rough cocksfoot grass (Dactylis glomerata), we shall find the larvæ of Elachista atricomella, luticomell a and cygnipennella; in the leaves of the turfy hair-grass (Aira caspitosa) the larvæ of Elachista albifirontella and zonariella occur; while in the leaves of the upright perennial brome-grass (Bromus erectus) we shall find the larva of Elachista subnigrella, and in the leaves of Eleocharis, mining downwards from the top, the larva of Elachista Rhynchosporella occurs.

On the water dropwort (Enanthe crocata), in that running stream, the splendid larva of Depressaria nervosa may be found; while outside the bark of the broom, in a bright white cocoon concealed beneath a bud, we shall find the pupa of Cemiostoma spartifoliella, and in rolled up alder leaves the larva of Gracilaria elongella occurs.

And now let us again look attentively upon the trunks of those trees grey with lichen: perhaps we may find Taleporia pseudobombycella; while on palings Tinea Lapella and Theristis caudella may be found.

Among sallow blossoms on sunny afternoons we may perhaps find the beautiful Adela cuprella; and on sandy heaths, flying at midday, Gelechia velocella occurs; while by sweeping the twigs of the birches we may obtain the pretty Micropteryx Sparmannella.

At "Headley Lane" we may obtain the larva of Gelechia ligulella between united leaves of the birdsfoot trefoil (Lotus corniculatus); while on the leaves 
of the same plant, in their cornucopia-like cases, we shall see the larve of Coleophora discordella; and the larva of Coleophora lixella on Holcus mollis; and the larva of the rare Coleophora conspicuella on the leaves of Centaurea Scabiosa and $C$. nigra; while on the stony places on "Box Hill" the larva of Glyphipteryx equitella may be found among the stonecrop (Sedum acre).

In grassy places among flowers Glyphipteryx fuscoviridella and $G$. Fischeriella may be found; while, among Plantago lanceslata, Gracilaria tringipennella occurs. But what is that pretty little insect flying in the sunshine along that hawthorn hedge, and making short excursions in to the neighbouring meadow? That is the "small yellow underwing," called also by some collectors the "strawber'y tree," Anarta Heliaca.

By beating among the underwood at "Coombe Wood," we may perhaps obtain Anchyloper'a siculana, readily recognized by the very produced tips of its anterior wings, which, when expanded, appear hooked.

Among furze we shall find Catoptria Ulicetana in plenty, and (but rarely) its beautiful variety decorana, Haw.

Upon Veronicx beccabunga, Pastinaca Sativa, and upon the common dock (Rumex obtusifolius), I have taken larvæ which have always produced insects, which I have referred to Sericoris lacunana; but it may be that the closely allied Sericoris herbana might have been bred amongst them, the food plants being so dissimilar. This mooted question might perhaps be set at rest by a careful examination of the larvæ, un- 
less Sericoris lacunana is polyphagous, like Sciaphila Virgaureana.

Mr. Ashworth in the "Zoologist," p. 4814, gives the following interesting notes of the habits of the handsome Accophora grandis :-

"Not uncommon in the end of May and June in one fence composed of a mixture of dead and living hazel and birch. They fly only in warm sunshine, from $10 \mathrm{a} . \mathrm{m}$. to $1 \mathrm{p} . \mathrm{m}$.; when the sun is off the fence they cannot be made to fly. I think they secrete themselves in dead leaves on the ground, they so soon become worn."

Among the orpine (Sedum telephium), Hyponomeuta vigintipunctatus occurs; Anesychia bipunctella on the bugloss (Echium vulyare); and among the common Cromwell (Lithospernum officinale) at "Darn" Anesychia decemguttella may be found; while Chalybe pyrausta occurs only in Sutherlandshire.

On dry sandy banks among sorrel (Rumex Acetosa) Gelechia diffinis occurs on heaths. In the north of England we shall meet with Gelechia longicornis, Ecophora subaquilea, Glyphipteryx Haworthana, and Pempelia carbonariella; while in the fens of Cambridgeshire and Huntingdonshire Tinea monachella occurs. Among maple we shall find Gelechia scriptella and Tinea picarella; while among hornbeam (Carpinus betulus) Tinea corticella occurs. Among sallows Nemophora Metaxella occurs; and Gracilaria stigmatella may be found among sallows and poplars; G. Swederella among oaks; G. omissella among mugwort (Artemisia vulgaris); G.auro- 
guttella among Hypericum perforatum; while the rare $G$. imperialella was "beat from a hedge, Glanville's Wooton, May 25th, 1840" (Entomologist's Companion, 2nd ed., p. 28). Among apple trees in gardens and orchards we shall find Ornix guttea and Trifurcula pulverosella, also among the wild apple trees in hedges, and together with Nepticula Malella on palings in their vicinity.

In waste places, among Chenopodium, Gelechia neviferella and Hermannella occur; while on sand hills on the Cheshire coast, we shall find Gelechia mundella; and on the sandy coast of the Isle of Wight Gelechia littorella may be met with.

At Darenth wood Acrolepia perlepidella occurs; while among the woody nightshade (Solanum dulcamara) Acrolepia pygmeana may be found flying freely in the afternoon sunshine.

At West Wickham, among oaks, by beating we may obtain CEcophora tinctella; while on sandy coasts and at Barnes Common, Surrey, Gelechia pictella may be obtained; and on the coast among thrift (Statice Armeria), we may capture Gelechia Brizella by sweeping.

In hedges, among oaks, we shall find the handsome Harpella Geoffrella; and on heaths Pleurota bicostelia occurs, together with Gel. ericetella. Among sloe bushes we may perhaps find $Y$ psolophus fasciellus, together with Ornix torquillella and Lithocolletis spinicolella; while in sandy or chalky places, among Helianthemum vulgare, Laverna Staintoni may be found; and in a moist place in West Wickham Wood Elachista occultella occurs. 
In hedges, among dog-wood, we may find the pretty Elachista Treitschkiella; while by sweeping in the hilly field at Headley Lane, and likewise at Darenth Wood, Elachista Brunnichella may be obtained. Among birches we shall find Ornix Devoniella and O. Betuke, together with Gelechia proximella; and on palings in their vicinity, Nepticula argentipedella, and Lithocolletis ulmifoliella and cavella may be found. In hedges, among hawthorn, Ornix Anglicella occurs together with Lithocolletis pomifuliella and corylifoliella; while on palings, near hawthorn, Nepticula pygmaella, Oxyacanthella, ignobilella and gratiosella may be found; while at the Isle of Wight, and at Howth near Dublin, Nepticula Acetose may perhaps be obtained by sweeping the sorrel (Rumex Acetosa); and on palings, near elms, Nepticula viscerella occurs, together with the pretty $N$. marginicolella. Among oaks we shall find $N$. atricapitella and ruficapitella, together with Bucculatrix Ulmella, and the Lithocolletides Roboris, hortella, Amyotella, lautella, quercifoliella, Messaniella, Caledoniella? Heegeriella, Cramerella, Dunningiella? and the rare irradiella; while among the grass on the ditch side Elachista atricomella, pulchella, Bedellella, obscurella, Megerlella and rufocinerea will reward the diligent collector; while the hedges will produce him Elachista Pfeifferella and Dasycera sulphurella; and in gardens the pretty little Plutella porrectella and cruciferarum may be found.

In the north, on the trunks of fir-trees, Ecophora similella may be found; while among thistles Gelechia acuminatella occurs. Among sallows we shall find 
Gelechia notatella; while among furze bushes Coleophora albicosta occurs, together with Butalis grandipennis; and in grassy places, where many flowers grow, Coleophora murinipennella and the beautiful Pancalia Leuwenhoekella occur. Among honeysuckle, in hedges, we may perhaps find Perittia obscurepunctella, and among honeysuckle in woods $\mathrm{Li}$ thocolletis Emberizepennella and trifasciella occur. Among nut-bushes we shall find Lithocolletis Coryli and Nicellii, together with Ornix Avellanella; and on palings in their neighbourhood Nepticula floslactella and microtheriella may be found. Among mountain ash Argyresthia conjugella occur's; whereas A. mendica frequents sloe bushes, and $A$. arceuthina and pracocella may be obtained by beating the juniper bushes on Sanderstead Downs, where the unique Lithocolletis triguttella was captured.

Among thite poplar's Lithocolletis comparella and Nepticula argyropeza, apicella and trimaculella occur, while among the common buckthorn (Rhamnus Catharticus) we shall obtain Nep. Catharticella; and by sweeping the Hypericum, probably $N e p$. Septembrella may be found, and, on paling near sallows Nep. Salicis, and Lithocolletis salicicolella; and in the west, L. Spinolella and viminiella; whilst among osiers, Lithocolletis riminetorum occurs, and among willows, Pempelia Adelphella may be found.

At Morpeth Lithocolletis nigrescentella occurs; $L$. quinqueguttella among sallows in Lancashire; $L$. Lantanella among the "mealy guelder rose" (Viburnum Lantana), at Mickleham, and L. Scabiosella 
among Scabiosa Columbaria near Croydon, and in Headley Lane.

Among alders we may obtain Lithocolletis alnifoliella, Stettinensis and Kleemannella; among hornbeam L. Carpinicollella and tenella; L. sylvella among maple; while on the trunks of elms, or on palings near them, the beautiful $L$. Schreberella and $L$. tristrigella may be found; and in gardens among laburnums (Cytisus Laburnum) we shall find the delicately pencilled Cemiostoma Laburnella. Among fern Lamprosetia Verhuellella occurs, while Gel. Anthyllidella may be found among Anthyllis Vulneraria, clover, \&c.; G. triparella among oaks; the destructive $G$. cerealella among barley, \&c. in granaries; Bucculatrix Cratcegi among hawthorn; while flying in the sun, round the twigs of the birch trees, Incurvaria muscalella and pectinea may be found; while of Argyresthia glaucinella $\mathrm{Mr}$. Ashwortl writes thus in the "Zoologist," p. 4815:- "Taken sparingly from the middle of May to the end of June sitting on the trunks and beaten from the branches of three or four very old half decayed trees."

Among the common reed (Arundo phragmites), in marshy places, Elachista cerusella occurs; while skimming over the moss, or settling on the blades of grass, \&c., we shall see Crambus pratellus and hortuellus, and in chalky places Crambus chrysonuchellus occurs.

On palings and trunks of trees we shall find $E u$ dorea ambigualis, while in sandy places, among the wild cammomile (Matricaria Chamomille), Homoosoma nimbella occurs. 
Among the great hairy willow herb (Epilobium hirsutum), Laverna Epilobiella, will be found; while by beating ivy we may obtain Laverna decorella; and sitting on the flowers of Stellaria holostea, Asychna modestella occur's.

Among the common hemp agrimony (Eupatoria cannabinum), Pterophorus microdactylus occurs. Of the very rare Pterophoms brachydactylus, "Professor Frey finds the larvæ on the underside of the leaves of Prenanthes purpurea in fir woods in May; that plant is not British, but is not unfrequently found in woods escaped from cultivation," (Entomologist's Annual, 1856, p. 60); and of Pterophorus tephradactylus "Professor Frey finds the larva on Solidago virgaurea in May. I met with the young larvæ on that plant at Clovelly in September." (Idem.) And in houses, and among honeysuckle in hedges, the pretty Alucitina polydactyla is common.

And now we will suppose the tyro, for argument's sake, to have worked assiduously at collecting the objects of his study, and by industry and perseverance to have got together a great number of species, which, apart from their intrinsic value as insects for the purposes of study, and as objects of great beauty and delicacy, possess an extrinsic value in his estimation, as being the fruits of his own labour and diligence, and as reminding him of the exquisite pleasure he has experienced in their collection. Full of this feeling, and wishing others to share his pleasures with him, he in an unlucky or incautious moment shows his treasures to some friend whom he wishes to entice into the ranks of Entomology; when, what is his disappointment to find his friend does not appreciate 
at all that which he values so highly, and slightingly inquires, "What is the use of it ?" Let not the tyro be discouraged by the wet'blanket thus thrown upon his pleasure; why should his spirits be damped at the unceremonious rebuff? Of what use is it for a man to ornament his parlour walls with choice paintings at extravagant prices, or his conservatory with beautiful exotics? The answer will probably be, because they refine the taste and elevate the mind. True! And will not the study of Nature's works, the investigation of the beautiful, and the delight engendered by it, elevate the mind, whether the object be a beautiful painting, or a beautiful insect coloured by the hand of the great Master of colour-God Himself? Most certainly it will; and more than that, the study of Nature will produce effects upon a well constituted mind that all the paintings, statuary and works of men's hands will never do. It will -

"Lead from Nature up to Nature's God."

And if the tyro is in possession of a microscope, the pleasures derivable from the study of Entomology will be increased a thousandfold.

I will finish this chapter by an extract from the "Exordium" of C. R. Goring, M.D., in the "Microscopic Illustrations," by Dr. Goring and Mr. Pritchard, in order that the tyro may be the less likely to have his ardour damped by well-meaning but mistaken friends: he says-

"I shall conclude this introduction by a vindication of microscopic science and its votaries from the aspersions that have been cast upon them by the incon- 
siderate, many of whom have been pleased to assert that microscopes have, of late, received a degree of patronage from the most illustrious and distinguished savans to which they are not legitimately entitled. Were they applicable to no other purpose than the dissection of blackguard vermin, the observation of stinking ditch water, or the amorous passions of ants and worms, I should perhaps, for argument's sake, admit that they were but the tools of a puny pitiful pedant, whose passions and amusements were of a trifling if not of a degrading complexion. But I would ask whether, in the hands of men like Bauer, they are not applied to the developement of the most curious, important and interesting details of anatomy and physiology, which without their assistance could never have beeu known? and whether the finest and most delicate parts of the structure of animals in their extreme penetralia are not rendered equally intelligible with the coarsest and most evident parts of their fabric by means of these instruments.

"Your life will not suffice to study sufficiently the wonders of the minutiæ of natural history.

"The supreme Author of Nature has been pleased to bestow so exquisite a degree of finishing upon many of His works that they can be only appreciated by man with the assistance of the microscope. Surely he who is but a work of God may be allowed to admire the norks of his Creator without incurring derision or ridicule, even though they are minutix. Trifles are said to take only with frivolous minds; but minutia are not necessarily trifles, as it will be easy to prove. It is not only, in my own opinion, unscientific, but 
even swinish and ridiculous, to condemn anything on account of its minuteness. To say nothing of the hackneyed argument, that greatness and littleness exist only by comparison, I will ask, if the automaton chess-player had been made on a scale of one twentieth of an inch to a foot, or even much less, it would, in consequence, become despicable as a work of art?

"Suppose some individual, greatly distinguished by his talents in ship-building, in making astronomical instruments, or steam engines, \&c., was also to evince a passion for making minute automata and watch-work, such as tarantula spiders, minute singing birds, musical seals, or even such curiosities as a coach drawn by fleas, \&c., would it show good breeding or good taste to despise or ridicule his minute labour's while we admired his grander and more imposing works?

"Now it does appear to me, that the Supreme Being does, in some sense, resemble such an individual; for His power loves to display itself in every way in which it can be displayed, whether upon the minute or grand scale, in the creation of animacules as well of fixed stars; and I cannot help thinking myself, that those who spurn and scoff at the minute works of God, be they what they may - while they affect an admiration of His great wonders--are guilty of a species of impiety, and must be either liars, or hypocrites or fools.

"Men are perpetually wondering, what can be the use of bugs, and fleas, and wasps, and such kind of vermin, and speak of them as absolute blots in the escutcheon of the Almighty. The use of these little insects is surely to teach man a perpetual lesson of humility. He is extremely apt to fancy himself the 
only being of real importance in this planet, and that every thing in it has been made for his exclusive use and accommodation; whereas a very little consideration must teach him that the said fleas, and bugs, and wasps, \&c., are intended to enjoy themselves in their own way just as he does; that is to say, without greatly considering the convenience, comforts or happiness of other beings. I consider it as certain that bugs were intended to prey upon man, as that man and the other predaceous mammalia were intended to destroy the weaker animals. If a bug (I beg pardon-a Cimex lectularius) could reason, it would probably suppose that man was of no other use in the creation than to prepare its habitation and supply its food; and would think that no better evidence need be adduced to prove the immense importance of a bug than that such bountiful provision had been made for it, \&c."

"He prayeth best who loveth best All things both great and small, For the dear God that loveth us, He made and loveth all." 


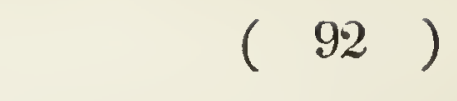

CHAPTER VI.

JUNE.

"It was the azure time of June,

When the skies are deep in the stainless noon,

And the warm and fitful breezes shake

The fresh green leaves of the hedge-row briar,

And there were odours there to make

The very breath we did respire

A liquid element, whereon

Our spirits, like delighted things

That walk the air on subtle wings,

Floated and mingled far away." - SheLLEY.

JUNE! delightful June! the crowning month of the year. The period of nature's adolescence has past, and the full and mature vigour of its puberty has commenced. The leafy wood, the smiling meadow, the breezy upland, the chalky down, the open moor or barren mountain side, covered with blooming heather, its fairy bells sparkling in the sunlight, and bending gracefully as the ever active and industrious bees rifle its nectaries of their choicest treasures. A large expanse of blooming heather is a glorious sight, recalling to the mind the stirring measure of the "Great Unknown," as he sings of raid and foray of "Douglas and the Graeme," and of the hardy clans Macdonell, 
Macdonald and Macallister, who chose these beautiful plants for their badges.

"The erica here,

That o'er the Caledonian hills sublime

Spreads its dark mantle (where the bees delight

To seek their purest honey), flourishes ;

Sometimes with bells like ametliyst, and then

Paler, and shaded, like a maiden's cheek,

With gradual blushes : others while as white As rime that hangs upon the frozen spray."

"Flower of the waste! the heath fowl shuns For thee the brake and tangled wood; To thy protecting shade she runs, Thy tender buds supply her food; Her young forsake her downy plumes To rest upon thy opening blooms.

"Flower of the desert, though thou art! The deer that range the mountain free, The graceful doe, the stately hart, Their food and shelter seek from thee; The bee thy earliest blossom greets, And draws from thee her choicest sweets.

"Gem of the heath! whose modest bloom Sheds beauty o'er the lovely moor ; Though thou dispense no rich perfume, Nor yet with splendid tints allure, Both valour's crest and beauty's bower, Oft hast thou deck'd, a favorite flower.

"Flower of the wild! whose purple glow Adorns the dusky mountain's side, Not the gay hues of Iris' bow, Nor garden's artful varied pride, With all its wealth of sweets could cheer, Like thee the hardy mountaineer. 
"Flower of his heart! the fragrance mild, Of peace and freedom seems to breathe; To pluck thy blossoms in the wild, And deck his bonnet with the wreath, Where dwelt of old his rustic sires, Is all his simple wish requires.

"Flower of his dear-lov'd, native land! Alas! when distant, far more dear! When he, from some cold foreign strand, Looks homeward through the blinding tear, How must his aching heart deplore, That home and thee he sees no more!"'

Mrs. Grant.

June is the jubilee of the year. Nature seems to have chosen it in an especial manner as her own; in it the trees attain their full leaf; the blossoms of the fruit trees have long since set, and the sun is gradually transforming them into luscious fruit, the gardens are drest in their gayest attire, the "rose of June" flaunts gaily in the nicely kept parterre, the birds are fully engaged in building their nests or rearing their newly fledged young, while the hosts of insect life swarm on every hedgebank, meadow, tree and bush ; on the open down, and in the tangled forest, on the weedy bank, and in the blossomy hedge-row, countless thousands sport their little day, and do the work appointed them to do.

"Is this a time to be cloudy and sad

When our mother Nature laughs around?

When even the deep blue heavens look glad And gladness breathes from the blossoming ground? There are notes of joy from the hang-bird and wren, And the gossip of swallows through the sky; The ground squirrel gaily chirps by his den, And the wilding bee hums merrily by; 
The clouds are at play in the azure space,

And their shadows at play in the bright green vale;

And here they stretch to the frolic chase,

And there they roll on the easy gale.

There's a dance of leaves in that aspen bower,

And a titter of winds in that beechen tree;

There's a smile on the fruit, and a smile on the flower,

And a laugh from the brook that runs to the sea;

And look at the broad-faced sun! how he smiles,

On the dewy earth, that smiles in his ray,

On the leaping waters and gay young isles-

Ay, look! - and he'll smile thy gloom away."

ANon.

And now, kind reader, while we are in this enviable frame of mind, let us betake ourselves to the London Bridge Station of the South-Eastern Railway, and, providing ourselves with tickets for the Box Hill Station on the Reigate, Guildford and Reading Branch, we shall, after about an hour and a quarter's riding through some of the most beautiful scenery in the vicinity of London, arrive at our destination, one of the most prolific localities in rarities both Entomological and Botanical, and embracing the most beautiful scenery with which I am acquainted.

Having arrived at the "Box Hill" station, and gained the road, we must turn to the right, and, continuing our course along the road until wearrive at the Burford Bridge Inn; we are then at the foot of Box Hill, as from the garden of the irm we can walk straight on to the hill, and so round to the left to the top of Headley Lane; but if we do not wish to explore the hill, but to make the "Hilly Field" the theatre of our explorations, we must continue our course along the 
road for some distance past the Burford Bridge Inn, until we come to a turning on our right; at one corner of which, in a garden, are some fine cedar trees, and at the other a direction post, on which is inscribed "Three miles to.Headley ;" this is Headley Lane. Continuing our course along the lane, we shall come to a farm house on our right-on our left a lime kiln; just past which, on the slope, we shall see a path arnongst the trees ; this will bring us into the "sanctum sanctorum," the "Hilly Field at Headley Lane." And now, how beautiful is the prospect! how varied is the scene! looking back upon the road we have travelled, the beautiful slopes of Norbury Park appear to great advantage, on which grow the noble old yews, the choice locality for Dasyrampa rubiginea; these yews are called the "Druid's Grove," but whether here in ancient times -

\section{"The incense rose}

That Pagan gods might crush the Briton's foes-"

is a point I am unable to set at rest, it being rather more antiquarian than Entomological; all I know is, that it could hardly have been more "sacred" then than now-"Trespassers will be prosecuted" being intended to strike terror into the hearts of all whom it may concern. But it is gratifying to think that the purse-proud lordling cannot destroy the pleasure his humbler (?) brother feels at contemplating the works of nature, and that all his gold and all his power cannot smother the feelings of admiration and pleasure that throng his heart as he stands in nature's temple and pours forth his soul in praise to the Author of all, for

"He looks abroad into the varied field Of nature, ind though poor, perhaps, compared 
With those whose mansions glitter in his sight, Calls the delightful survey all his own.

His are the mountains, and the valleys his, And the resplendent rivers : his to enjoy With a propriety that none can feel, But who, with filial confidence inspired, Can lift to heaven an unpresumptuous eye, And smiling say, "My Father made them all!" Are they not his by a peculiar right, And by an emphasis of interest his, Whose eye they fill with tears of holy joy, .

Whose heart with praise, and whose exalted mind,

With worthy thoughts of that unwearied love, That planned, and built, and still upholds, a world So clothed with beauty for rebellious man ?"

COWPER.

The soil is chalk, through which the green sand peeps in places, while the vegetation is luxuriant beyond description; the trees are principally beech and birch, intermixed with hazel, oak and juniper; while the herbage beneath is a perfect earpet of flowers, marjoram, wild thyme and cowslips (here provincially called "Paigles"), together with Orchidece, and many other rare plants. But let us commence operations, and first we will beat those yew trees upon the hill; hilloa! what is this plain yellowish insect I'have beaten out? Let me see! a good beginning, that is Lithosia helvola; try again; good! Aventia flexula now! Our luck has set in ; and, while "the tide" of oul affairs is at the flood, let us make our' 'Entomological fortune if we can, and to this end let us search those beech trees, and, perhaps, we may find Tortrix cinnamomeana. In "Headley Lane" Lithosia complana occurs; while among the birches we may find Ephyra orbicularia. In the 
Hilly Field Eupithecia piperaria occurs ; while among Spircea filipendula the larvæ of Peronea aspersana occur abundantly. Among the spruce firs Coccyx nanana occurs; while Stigmonota coniferana has been taken once upon the same trees, and among the beeches Stigmunota Weirana may be found.

In Headley Lane we may find Setina irrorella; Penthina sellana occurs in the Hilly Field. Among beech trees Lithosia aureola occurs, while on the trunks of trees Stauropus Fagi may perhaps be found; while feeding in the evening at the flowers of Silene inflata we may see Dianthcecia carpophaga. Among bushes, by beating, we may obtain Toxocampa pastinum; while among oaks Catocala promissa and C. sponsa occur; and on Mickleham Downs Boarmia Abietaria may be found. In the "Hilly Field" Pyrausta cingulalis and $P$. anguinalis occur, together with Cledeobia angustalis and Botys hyalinalis; while on Mickleham Downs Sericoris decrepitana occurs on Scotch firs, and Mixodia Ratzburghiana on larches.

Among beech trees Carpocapsa grossana occurs; C. splendana among oaks, and C. Pomonana among apple trees. In a house at West Humble Tinea Luzella has occurred, while CEcophora flavifrontella is found among privet. "Herr Krösmann has bred this from a singular case found on the ground; the case is rather semicircular and broad at its straight edge." (Entomologist's Annual, 1856, p. 54.)

By sweeping we may obtain Gelechia Coronillella, while among the stone-crop (Sedum acre), growing in a stony place on Box Hill, we shall find Glyphipteryx 
equitella; while in the juniper bushes Argyresthia abdominalis occurs, together with $A$. arceuthina and precocella; and on Sorbus aria, Argyresthia Sorbiella may be found, while among the viper's bugloss (Echium vulgare) Coleophora Onosmella and Douglasia Ocnerostonella may be met with. In grassy places, under the shelter of bushes, Elachista gangabella occurs, together with Pterophorus tetradactylus.

And now let us diversify our occupation a little, and commence a hunt for our pets in embryo: and first what are those blotches on the leaves of Centaurea scabiosa and $C$. nigra caused by? Let us look. Ah! another slice of luck, one of the gems of Headley Lane, the best plum in the Micro-Lepidopterological pudding, the larva of Coleophora conspicuella in its black case, in appearance resembling that of $C$. albitarsella, but twice as large. On Echium vulgare we shall find the larva of Col. Onosmella. On the perennial goose-foot (Chenopodium bonus-Henricus) the larva of Heliodines $R$ oesella may perhaps be found feeding gregariously in a web on the under side of the leaves.

Mining in the leaves of Artemisia vulgaris the larva of Gracilaria omissella occurs; while in the leaves of lilac, privet and ash, at first mining and afterwards folding the leaves into a cone, the larvæ of Gra. syringella may be found in plenty; and in the leaves of the ribbed plantain (Plantago lanceolata) the larvæ of Gracilaria tringipennella may be found in their brown mines, while the pretty and conspicuous black larva, spotted with white, of Tortrix Icterana (proF 2 
ducing males only) fold the leaves over, joining them tubularly.

Among the St. John's wort (Hypericum perforatum) the larva of Gracilaria auroguttella have reestablished their "cigar" manufactory, while in the leaves of the aspen (Populus tremula) the larvæ of Phyllocnistis suffusella make their curious mines; and in the leaves of the willow the larvæ of Phyllocnistis saligna are busily engaged on a similar operation.

In the leaves of Epilobium hirsutum (Circea lutetiana?) (Entomologist's Annual, 1st ed., p. 63, 2nd ed., p. 85), we may perhaps find the larva of Anybia langiella; while among Cherophyllum sylvestre, Sison and other Umbelliferce the larvæ of Chauliodus Charophylellus will be found, discolouring the leaves; and on the leaves of Stellaria holostea, the larvæ of $\mathrm{Co}$ leophora solitariella occur, while the larvæ of Gelechia maculea may be found devouring its shoots and seeds. In wet places, mining the leaves of the flea bane (Inula dysenterica), the larva of Acrolepia granitella occurs (it has the power of moving from leaf to leaf); while burrowing in the leaves of the burrreed (Sparganium), the larva of Orthotalia Sparganella may be found. In shoots of heather the larva of Gelechia ericinella may be obtained.

Under the leaves of thistles, in a slight web, we may find the larva of Depressaria subropinquella; while, in the turned-down corners of Centaurea nigra, the larva of Depressaria arenella will be found, and in its rolled-up leaves the larva of Depressaria liturella finds a congenial home. 
In the shoots of Genista tinctoria the larva of Gelechia lentiginosella may be found, together with that of Depressaria atomella; the latter also in the shoots of broom (Spartium scoparium); while the larva of Depressaria costosa feeds in the shoots of furze and broom indifferently.

In the shoots or tops of Hypericum perforatum, the larva of the pretty Depressaria Hypericella may be found; while in the shoots of sallow that of $D e$ pressaria conterminella occurs, together with that of Depressaria Angelicella - the latter also upon Angelica sylvestris in wet places.

On limes and sallows we may find the larva of Cerostoma sequella, while on and in? the leaves of lime, horse-chestnut, birch? and alder the larva of that great rarity Bucculatrix Hippocastanella occurs; and on the twigs of the juniper, making large webs, the larvæ of Y psolophus marginellus may be found; and under the leaves of the goosefoot (Chenopodium) and the orache (Atriplex), in a slight web, we may perhaps find the larva of Butalis Chenopodiella, while in the shoots of Atriplex the larva of Gelechia Atriplicella occurs; and in the stems of both Atriplex and Chenopodium the larva of Gelechia obsoletella may be found, while the larvæ of Gelechia naviferella and $G$. Hermannella are busily engaged in mining the leaves of those plants, forming large whitish blotches.

In the shoots of broom (Spartium scoparium) the larva of Anarsia Spartiella occurs, while in the shoots of the dyer's green-weed (Genista tinctoria) the larvæ of Anarsia Genistce may be found; while 
the umbels and stems of the cow-parsnip (Heracleum sphondylium) are inhabited by the larvæ of Depressaria Heracliana. On the yellow hoary mullein (Verbascum pulverulentum), in turned-down corners of the leaves, may be found the pupæ of Nothris Verbascella (but this has only hitherto occurred near Norwich), while the larvæ of Psoricoptera gibbosella, and Gelechia temerella and sororculella occur on sallows.

On ash trees we may perhaps find the larva of Zelleria hepariella, while on spindle (Euonymus) the larvæ of Hyponomeuta plumbellus, irrorellus, Evonymellus and Theristis caudella occur; and in the leaves of Epilobium hirsutum the pupa of Laverna ochraceella may be collected. The pupa of Chrysoclista Linneella lies snugly ensconced beneath the bark of lime trees.

In decayed wood the larva of Exapate gelatella luxuriates, while on oaks the curious footed larva of Chimabacche phryganella may be found; and on hawthorn, in a web gregariously, the larva of Scythropia Cratcegella occurs, together with the active larva of Swammerdamia Pyrella on the same food plant.

In gardens, on cabbages, \&c., the larva of Plutella cruciferarum occurs, while in the orchards and gardens, on sloe, hawthorn and apple, the larvæ of $H y$ ponomeuta Padellus carry on their work of destruction and disfigurement, in company with the larva of Clisiocampa neustria; and on the dames violet or rocket (Hesperis matronalis) will be found the larva of the pretty Plutella porrectella, while on apple trees we 
may hope to find the larvæ of Cerostoma asperella and Gelechia rhombella; and from off the bark of pear trees the pupæ of Gelechia nanella may be collected.

On the bird-cherry (Prunus Padus) the larva of Hyponomeuta Padi occurs, while on oaks we may find the larvæ of Cerostoma sequella and Gelechia gemmella (mining the leaves?); and on the orpine (Sedum telephium) we may perhaps find the larva of Hyponomeuta vigintipunctatus, and descending from birch trees, in their newly made cases, the larva of Incurvaria pectinea may be observed.

On Chcerophyllum sylvestre the larva of Depressaria Weirella may be found, while under the leaves of pear, oak and beech, in a slight web, the pretty larva of Phibalocera Quercana devours the under epidermis and parenchyma of the leaves, making brown blotches.

On elm, alder, hornbeam and nut we shall find commonly the larva of Coleophora fuscedinella, while on the leaves of Genista tinctoria the larva of Coleophora vibicella occurs, and in bramble leaves the larva of Nep. aurella; while in fungi on hornbeam we shall find the larva of Tinea corticella, and the larva of Gelechia sequax in the shoots of the common sun cistus (Helianthemum vulgare), and that of $G$. populella on poplars, sallows and birches.

And now the larvæ of the delicate, graceful and beautiful "Plumes" (Pterophori) demand our attention. These larvæ are all hairy, and feed mostly on the under side of the leaves of their respective foodplants. Under the leaves of the burdock (Arctium Lappa) we shall find the larva of Pterophorus galac- 
todactylus, while on the leaves of the flea-bane (Inula dysenterica) the larva of Pterophorus lithodactylus occurs; and on the leaves of the common white horehound (Marrubium vulgare) we may perhaps be fortunate enough to find the larva of Pterophorus spilodactylus, while that of Pterophorus pentadactylus devours the leaves of the small bindweed (Convolvulus arvensis), and that of Pterophorus phcodactylus occurs both upon the trailing and thorny rest-harrow (Ononis procumbens and $O$. spinosa) indifferently. On the narlow-leaved hawkweed (Hieracium umbellatum) the larva of Pterophorus Hieracii occurs; while upon the common mouse-ear hawkweed (Hieracium pilosella) the larva of Pterophorus Pilosella may be found.

And now, kind reader, let us in fancy transport ourselves to some delightful expanse of heather, alive with the myriad insects that find food and shelter amid its dense foliage, and musical with the hum of bees : such an one is the heath field at Coomb Hurst, and its ditto at West Wickham; and now let us commence operations.

Hilloa! hi! where are you running to as if you had been frightened? Where! why after that beautiful insect, darting along over the heather! Well! and did you catch it? No, the rascal could fly considerably faster than I could run with my feet hampered by the heather! Exactly so, the only way to catch that elegant and active insect is by standing still. What! standing still? Seriously! are you joking? Joking? no, never was more serious in my life. Just take up your position, net in hand, in the sunniest spot 
you can find among the heather, and standing still await their approach and "bag" them. That is it. Good! four specimens in a very short time, taken by standing still. That is the only way you can surely capture the beautiful but rapid-flying Anarta Myrtilli, which would have led you a dance over the field again and again, and then have eluded your pursuit, simply because its habit is to fly rapidly and in the bright sunshine over the heather, hiding itself among the heather if the sun becomes cloudy, and reappearing as soon as he shines again; feeding upon the heather you will find the beautiful green larva of the same species.

On the trunks of the oaks the pretty little Coccyx argyrana will be found, while among the thistles Ephippiphora sticticana occurs; and flitting along among the coltsfoot (Tussilago farfara) we shall see Ephippiphora Brunnichana, while on the trunks of trees and hidden among the heather Pedisca corticana occurs.

Among the tansy (Tanacetum vulgare) Dicrorampha sequana occurs, while among sycamores we shall find the pretty Stigmonota Trauniana, and Penthina Betuletana among birches; among the brambles we shall find Notocelia Udmanniana, while on the sandy bank (among Hypericum perforatum) Catoptria Hypericana may be found; and Catoptria Albersana occur's among honeysuckle at "West Wickham;" Catoptria Hohenvorthiana among thistles, and $C$. pupillana on the coast among the sea wormwood.

Now there are a great number of insects that do not F 5 
come to sugar, but flit about in the twilight. As soon as the sun has descended below the horizon, and the fields and woods begin to be enveloped in shadow, we may see a number of moths carefully threading their way among the bushes, hovering over the weedy banks, or gamboling in the dusky twilight about the tops of the low underwood, or among the lowermost branches of the trees; upon examination these will be found principally to consist of Geometra, Pyrales and Tortrices. Being armed with a net, we have only to capture them-this may easily be done, as they are wholly intent upon feeding upon the flowers or enjoying their twilight gambols-pinning them and transferring them to your damp collecting-box, or, in the case of small Geometre and Tortrices, enclosing them in pill boxes for future disposal. This process of obtaining insects is very productive, and is technically known by the appellation " mothing." It can also be practised at a time of the day which can hardly be appropriated to anything else in the way of collecting, as it is too early in the evening for sugar and too late for beating; so that while awaiting the "sugaring" time, the intervening period may be profitably employed in " mothing."

But while we have been talking, twilight has been gathering, and our little pets are flitting and bobbing about in all directions. What is that delicate and pretty insect, like a small Ennomos, hovering about that privet at the edge of the wood? That is Pericallia Syringaria, the lilac beauty; but see, there are some more "beauties" flying by: dart over and among that underwood; capture one or two; they are Ange- 
rona prunaria. You see the male and female are very dissimilar, the male being orange, mottled with small black markings, and the female having a broad stripe or fascia of lemon yellow through the dusky anterior wings, and a large spot of the same colour on the under wings. There is also another insect very dissimilar in the sexes; this is Fidonia Piniaria, but the colours are transposed; the female in this species being orange, with a large dusky apical patch, and the male lemon yellow, the apical patches being black. This species is taken at West Wickham and Ripley flying round pines in the sunshine, but requires a longhandled net to capture it, as it flies rather high. Flying along whitethorn hedges we shall see Rumia Cratagaria, together with Ourapteryx Sambucaria, readily recognised by the tail-like processes at the edge of the posterior wings, while Ellopia fasciaria occur's among pines. On heaths Fidonia atomaria occurs; while Eupisteria carbonaria occurs on heaths in Scotland, Perthshire, together with Psodos trepidaria in the same locality. Among birches we shall find Biston betularia, while on the trunks of oak and pines Odontopera bidentaria will be found. On the trunks of trees and on palings Aplecta tincta may be found, together with Acronycta Aceris and megacephala; while on palings near gardens Polia serena occurs, together with Bryophila perla and glandifera. The handsome but common Plusia gamma may be often found at rest on weedy banks, and $P$. Chrysitis among nettles; while $P$. Orichalcea occurs on the coast near Deal, and $P$. Bractea in the north of England, together with $P$. interrogationis; Plusia Iota occurs on 
hedge banks among ground-ivy, on which the larva feeds.

On palings (Dartford Heath) Eupithecia venosaria occur's, June 8th, together with Anchylopera Ramana and Tortrix minutana; palings are the great harbour for the Eupithecice and Dosithere; here they may be found with their wings expanded, and compressed as flat as possible against the paling - their brown or dark colour greatly aiding their escape from the searching eye of the Entomologist - while on the least alarm they are ready to start at a moment's warning; in such situations Eupithecia rectangularia, debiliaria, pumilaria, castigaria, austeraria, innotaria, minutaria, subnotaria, plumbeolaria, Centaurearia and irriguaria, may be found, together with Dosithea virgularia on palings near gardens.

In bushy places near woods, and on the skirts of woods, we may obtain, by beating, those beautifully marked Geometra (called "carpets" by collectors), of the generæ Emmelesia, Harpalyce, Melanippe, \&c.; in such localities we may obtain Emmelesia decoloraria, blandiaria, rivularia and bifasciaria, together with Harpalyce marmoraria, picaria, fulvaria and galiaria, Melanippe tristaria, Alchemillaria and amnicularia, together with the beautiful argent and sable Melanippe hastaria. This insect flies in the day time in the open spaces in woods (at West Wickham it is not uncommon) at a considerable elevation; but if the collector seeing one, follows it a short distance, it will probably be espied by another of its own species, when immediately a battle will commence between them, in the course of which they will approach nearer 
the earth, when they may be captured by the watchful Entomologist : or should not another insect appear in sight, to commence a fight and thus increase the gains as well as the pleasure of the collector, a few small pebbles or pieces of clay being thrown vertically upward so as to attract its attention, the pugnacious disposition of the species will be developed, and it will descend rapidly after the challenging missile in order to give it battle, and will thus be brought within reach of the collector's net.

Among osiers Tortrix clorana may be found; while Halias prasinana and Quercana occur among oaks and hornbeams, together with Tortrix viridana among oaks; $T$. adjunctuna among honeysuckle and ivy; $T$. Sorbiana among hazel; and T. Ribeana, unifasciana, Rosana and pyrastrana in gardens.

This month is very prolific in insects at "sugar." The sugar should be placed upon the trunks of the trees, on posts, smooth stones, felled timber, or any other convenient places, in long streaks, by means of a painter's brush, about an hour before sunset, between which period and the time you commence examining your "sugar" may be profitably employed in mothing. The first indications of Noctuce, or such other insects as will visit your "sugar," being astir, will be the appearance of the swifts, Hepialida. This genus must have received its common designation of "swifts" from the species lupulinus and velleda, from their quick and rapid flight, in marked contradistinction to the species Hectus and Humuli, whose flight is a slow, hovering, pendulum-like motion. After these come the peach blossoms, Thyatira batis, daintily careening over the 
brambles, and, if the night be calm, they will soon discover your sugar; then the smaller fry of Depressaria, Tinece and Tortrices, with an occasional Pyralis, make their appearance until twilight deepens into the deep shades of evening, when the Noctuce, that especially favour the saccharine repast, make their appearance, their brilliant eyes burning like lamps as they sit on the "sugar" that has "betrayed them into the hands of the fowler." Of those species that most commonly come to sugar, we may enumerate Noctua festiva, C. nigrum, Phylopira tragopogonis, Nrenia typica, Agrotis putris, Acronycta Aceris and megacephala, Bryophila perla and glandifera, Ceropacha fluctuosa and duplaris, Phlogophora meticulosa, Agrotis segetum, suffusa, puta and exclamationis; while, as "sugar" plums, we may occasionally capture Agrotis lunigera (in the Isle of Wight), Acronycta Alni, auricoma and Ligustri, Dipthera Orion and Cymatophora $\mathrm{O}_{0}$.

Light is also very attractive; all the Bombyces and many of the Sphingidee are attracted by it, and, in country or suburban districts, often make their way into the gas lamps by running up the lamp posts, and so make their way in by the hole at the bottom of the lamp, through which the burner passes; but once in, it is impossible for them to get out again, for, from the universal tendency of all moths (as well as larvæ) to crawl upwards, they often get to the top of the lamp, and so over the flame, in which position they get scorched to death, their wingless and shrunken bodies, on the bottom of the lamps, testifying to the cause of death; and thus they become martyrs to their love of light. 
In this way may be obtained many rare species,Notodonta dromedarius, Ptilodontis palpina and Chorocampa Elpenor, while Smerinthus Populi occurs commonly, and S. Tilice and ocellatus more sparingly, and Pygara bucephala in abundance, together with a good supply of Geometra; the commoner species often in little swarms, together with Pyralides and Crambina.

There are also many plants and shrubs which are extremely attractive to Lepidoptera, at the flowers of which they may be readily captured while sporting over them, and buzzing or feeding at them. Of these Silene inflata, Virginia stock, honeysuckle, common red Valerian and the blossoms of the lime tree, now deserve our attention.

There are three Tinea that demand some notice, viz. : Acrolepia perlepidella, Nothris Durdhamella and Coleophora ochrea. Of the rare Acrolepia perlepidella it is stated (Entomologist's Annual, 1856, p. 54), "Mr. Vaughan took about ten indifferent specimens, August 28th, 1854, flying in the sunshine round a privet-bush, surrounded by oaks and birches, in Leigh Wood, near Bristol! This year Mr. Vaughan again met with the species in the same locality, June 18th and 28th."

Of Coleophora ochrea Mr. Stainton states (Entomologist's Annual, 1856, page 55), "The larva feeds, so Herr Schmid assures me, on Helianthemum vulgare, the latter half of June eating the leaves. The case must be very conspicuous; it is more than half-aninch long, cylindrical, brownish-ochreous." While of Nothris Durdhamella, it is the solution of Enigma 
No. 13 (Ent. Annual, 1st edit. p. 64 ; 2nd edit. p. 86), " ' the black and white larva, not unlike that of Gelechia rufescens,' was found by Mr. Harding at Deal, on the Origanum vulgare, at the end of June." (Ent. Annual, 1856, p. 53.)

And now, dear reader, I will close this chapter with a few words of advice, which I hope will be of service to you. We have now entered upon the most prolific season of the year in insect life; the fields and woods are alive with insects, and the tyro may be tempted to take, and undoubtedly will take, all he can of the "little gem-like atoms of God's creation" so profusely scattered abroad; but I sincerely hope that when he has taken them, brought them home, and killed them, he will set them, and not allow them to remain in his laurel box until they become mouldy, or take them out, insert a pin through the thorax of each specimen, then stick them with their wings closed in a store box, or on a spare piece of cork, and then leave them to take care of themselves, or to become a prey to mites, spiders and mould, instead of increasing his stock of duplicates wherewith to oblige his friends who are in need of the species he thus wastes. Such conduct brings its own punishment: mites make their appearance in his collection (and it is remarkable that these creatures seldom attack common insects; and I believe almost every Entomologist will confirm my statement, that it is usually the rarest insects that first become their prey); spiders are fostered, dirt is engendered, and lazy, indolent habits are formed insensibly by the tyro until he loses his energy, and his collection falls into decay. 
Often have I seen dozens of pill-boxes emptied of their defunct inhabitants and scores of insects consigned to the flames, that by the exercise of a little industry might have been retained in good condition by their owners, or have formed a most acceptable and welcome present to some Entomological tyro.

But, further, we have no right to destroy indiscriminately and purposelessly any of the innumerable living creatures that inhabit and beautify this earth.

"They are as free to enjoy as we to live."

Why then should we wantonly cut short their little span of existence, and then suffer them to decay, useless alike to ourselves and others? Be sure the tyro who is habitually guilty of such conduct will never become an Entomologist in heart. Nature is never wasteful of animal life! why then should man be? How do we know that the Great Author of their being (as well as our's) does not hold them in his estimation as especial evidences of his creative power, seeing that he has not only endowed them with great external beauty, but has given even the smallest of them a muscular system of such power, that if the elephant was endowed with the strength of these insects, in proportion to his size, his powers of destruction would be fearful to contemplate.

Thomas Rymer Jones, F.R.S. (in his "General Outline of the Animal Kingdom," page 250, paragraph 292), says :-

"The muscular system of insects has always excited the wonder and astonishment of the naturalist, in whatever point of view he examines this part of their eco- 
nomy-whether he considers the perfection of their movements, the inconceivable minuteness of the parts moved, or the strength, persistence or velocity of their contractions." Insects are proverbially of small comparative dimensions_- "minims of nature"-_

" that wave their limber fans

For wings, and smallest lineaments exact,

In all the liveries decked of summer's pride."

Their presence, indeed, around us, is only remarked as conferring additional life and gaiety to the landscape; and, except when by some inordinate increase in their numbers they make up by their multitude for their diminutive size, the ravages committed by them are trifling and insignificant. Far otherwise, however, would it be if they attained to larger growth, and still possessed the extraordinary power with which they are now so conspicuously gifted; they would, then, indeed, become truly the tyrants of the creation; monsters such "as fable never feigned or fear conceived," fully adequate to destroy and exterminate from the surface of the earth all that it contains of vegetable or of animal life.

We have already seen that the flea or the grasshopper will spring two hundred times the length of its own body; that the dragon-fly possesses such indomitable strength of wing that for a day together it will sustain itself in the air, and fly with equal facility and swiftness backwards or forwards, to the right or to the left, without turning; that the beetles are encased in a dense and hard integument, impervious to ordinary violence; and, we might add, that the wasp and the termite ant will 
penetrate with their jaws the hardest wood. Neither is the velocity of the movements of insects inferior to their prodigious muscular power. "An anonymous writer in Nicholson's Journal," say Kirby and Spence, "calculates that in its ordinary flight the common house-fly (Musca domestica) makes with its wings about six hundred strokes, which carry it five feet every second; but if alarmed, he states their velocity can be increased six or seven fold, or to thirty or thirtyfive feet in the same period. In this space of time a race-horse could clear only ninety feet, which is at the rate of more than a mile in a minute. Our little fly, in her swiftest flight, will in the same space of time go more than the third of a mile. Now, compare the infinite difference of the size of the two animals (ten millions of the fly would hardly counterpoise one racer), and how wonderful will the velocity of this minute creature appear! Did the fly equal the race-horse in size, and retain its present powers in the ratio of its magnitude, it would traverse the globe with the rapidity of lightning." **

Let the reader, therefore, imagine for an instant that great law of nature, which restricts the dimensions of an insect within certain bounds, dispensed with even in a single species. Suppose the wasp or the stag-beetle dilated to the bulk of a tiger or of an elephant-cased in impenetrable armour - furnished with jaws that would crush the solid trunk of an oak-winged, and capable of flight so rapid as to render escape hope-

* Kirby and Spence, Op. Cit. vol. ii. p. 358. 
less;-what would resist such destroyers, or how could the world support their ravages?

Go, child of nature to thy mother's breast, And learn the lesson she can teach so well;

No longer in the lap of folly rest, But hear the truths that Nature loves to tell. Go to the forest when the tempest lowers; List to the roaring of the mighty wind : Ask by what force the raging torrent pours, Or why the wilderness it leaves behind. Go to the bubbling fountain and the rill, Or mark the gentle fall of silent dew : Ask whence the stream its wasted course shall fill, Or who the lapse of waters will renew. Go to the bee, and watch its daily toil, And ask what sweetens labour and repose, Who bears it onward laden with rich spoil, And guides it home to rest at evening's close. Go to the bird, that seeks her leafy nest, To guard her young ones with her sheltering wing: Ask who it is that plumes her downy breast, And tunes her voice to music while she sings. Go to the streamlet, murmuring through the vale; Gaze on the wreathing flowers that o'er it twine; Will they not tell their own untutored tale, And say, "The hand that made us is Divine?" " 


\section{( 117$)$}

\section{CHAPTER VII.}

\section{JULY.}

"What more felicity can fall to creature

Than to enjoy delight with liberty?"

\section{SPENSER.}

"The love of Nature and the scenes she draws

Is Nature's dictate. * * * * *

The air salubrious of her lofty hills,

The cheering fragrance of her dewy vales

And music of her woods."

\section{Cowper.}

"We feel within ourselves

His energy divine; he tells the heart

He meant, lie made us to behold and love

What he beholds and loves, the general orb

of life and being. * * * * *

Thus the men

Whom Nature's works can charm, with God himself Hold converse, grow familiar, day by day, With his conceptions."

\section{Akenside.}

AND this is July! Hot, baking, sultry July! in which the dog-days hold undisputed sway, in which the sun darts his powerful rays in an almost vertical direction upon us, causing the soil to crack with the heat, and 
the chalk-cliffs and the marsh to shine like polished silver in the effulgence of his rays.

The noise of the humble bee, which in the early morning might be heard beside every hedge-row and on every weedy bank, along which the black and yellow-coated gentry winged their way, has ceased, the Bombi having retired into their holes until the heat of the day has past; while, on the contrary, the pretty little Cicindela campestris is in full activity, running swiftly along the sandy bank, or making short excursive flights along the hedge-row. The corn just coming into ear stands almost erect, gracefully bending to the soft zephyr-like wind, that comes in little gusts from the south-west, while the gaudy poppy and the scarlet pimpernel (its brilliant blossoms fully expanded to Sol's refulgent beams) beautify the ground.

But let us leave the fields and retire within the leafy expanse of the woods, beneath the verdant shade of which the heat has driven the birds to take shelter. And let us rest awhile our languid limbs beside the cool margin of the brook, over the surface of which those tyrants of the insect world, the Libellule or dragon flies, dart with the rapidity of arrows, and into which the kingfisher (Alcedo ispida) plunges, looking as cool, and comfortable, and unconcerned as if it were anything but a baking July day, and provoking us to emulate him in his refreshing ablutions.

But what is this? The dragon flies have ceased hawking and have retired among, or are hanging to, the sedge and rushes on the brook side; the kingfisher has disappeared; the wind no longer comes in slight gusts, but "soughs" among the trees, making the 
leaves of the birch and aspen vibrate upon their slender stems, and the tops of the tall pines bend and creak before it; the birds have ceased their calls and taken refuge among the trees and underwood; the monotonous caw! caw! of the rooks is heard overhead, as they hurry home from their feeding-grounds; the sky, erewhile so intensely blue, has become covered with one mass of leaden clouds-all animated nature seems hushed, not a sound is heard save the croak of the frog from his marshy covert, or the song of the blackbird, or the storm-cock (Turdus viscivorus) from the top of yonder elm-save these sounds all is stillpat! pat! pat! fall the large drops of rain upon the leaves overhead, at first slowly and in measured time, then faster, faster still, until the clouds pour forth their burden in continuous streams - the frogs croak the louder-the storm-cock shouts peto! peto! peto! more energetically than ever, as if exulting in the deluge of waters, when suddenly the clouds open, the forked lightning descends, cleaving in twain in its course yon noble oak, while the artillery of Heaven shakes the firmament. **** The rain relaxes in its violence, the clouds break up and move slowly before the wind, and the blue sky appears again - the sun shines in his splendour, his rays, refracted by the rain-drops on every leaf and branch, convert them into sparkling gems - - the birds forsake their leafy sanctuarythe dragon fly and kingfisher are again darting over the brook - the pimpernel has ope'd her scarlet eyethe hum of the bee is again heard-the skylark rising from the corn pours forth floods of melody -hundreds of young frogs are skipping about in all directions, 
enticed abroad by the copious moisture-a delightful coolness pervades the air-all nature feels refreshed, and no record remains of the strife of the elements but yonder rifted oak.

And now, dear reader, I am going to take a trip across the-_"say" to the "land of St. Patrick," the "gem of the ocean," to that "sister island" in the broad Atlantic which Tom Moore designates as-

"An emerald set in the ring of the sea."

And should any of my readers ever in this age of cheap travelling avail themselves of Mr. Marcus' excursion trains, by which they may travel to Dublin and back "for thirty shillings," they will not be unprofitably employed (in an Entomological sense) by visiting the locality I purpose directing them to, and to which I will shortly call their attention.

Ireland, as far as Lepidoptera are concerned, has not as yet produced, and I don't think contains, so many species of insects as Eugland. Nevertheless she produces many rarities, and some species in abundance that are only occasionally or sparingly obtained in England. This scarcity of species is, I think, in a great measure caused by the absence, in a great degree, of old wooded districts in Ireland, and to the large extent of bog, heath and rocky ground, as well as to the mildness of its winters, a circumstance that is highly unfavourable to the development of Lepidopterous insect life; but, however this may be, I have not the least donbt that Ireland, if well worked, would produce an abundant harvest of rarities of the families Tortricina and Tineina. Of the other families 
of Lepidoptera I cannot speak so positively, as I do not think the peculiar features of the country favourable to their production, from, as I before stated, the absence of old wooded districts; but I sincerely hope that some of the members of the "Dublin University Zoological Association," and the other Natural History Societies in Ireland, will bestir themselves, and that, by their exertions, we shall hear that there is more in her than we give her credit for, and that in this, as well as in other thing's, the dawn may only give place unto the perfect day.

But to return from this digression. The locality to which I purpose to conduct my readers is "Howth" and its vicinity.

Let my reader suppose himself located in the fair city of Dublin, and, being entomologically inclined, pondering where it would be best to direct his steps in order to obtain the greatest chances of success. His ideas of an Entomological locality would probably point to the south side of the city as the most favourable by its position; such is not the case, the north side of Dublin is the best and most productive; from its soil being limestone it seems to be analogous with the chalk districts of Kent and Surrey, while its position being on the coast it enjoys a temperature equal to the famous south-east coasts of Deal and Dover.

Having chosen the locality which we intend visiting, let us make the best of our way to the station of the "Dublin and Drogheda Railway" in Amiens Street; and obtaining our tickets for the "Baldoyle and Sutton" Station, we shall, after about twenty-five minutes riding, be startled by the cry (as the train draws up 
at the Station) of "Baldoyle and Sutton," "Baldoyle and Sutton," "Tickets, gentlemen!" "Tickets! tickets! tickets!" when, having alighted, and complied with the request for our tickets, if they are single journey ones, or given up the half if return ones, we walk along the platform-descend the steps, and, turning to our left, proceed along the lane in the direction of the "Howth Road," into which the lane leads. And here, already, we are in good collecting-ground, for the lane is walled on each side by turf walls; and, perhaps, it may not be amiss to describe these walls, which afford such good collecting. They are mostly about three or four feet high, by eighteen inches thick, and are composed of alternate layer's of grassy turf, placed topsy-turvy, $i$. e. with the grassy side downwards and the eartlyy side upwards, and layers of ditch mud, or earth wetted with water, and mixed with short straw; these walls, as a matter of course, present an admirable surface for the propagation of plants of every conceivable kind, as from their form they present different aspects, together with great shelter for insects; and when of a considerable age are covered with an extremely rank regetation, rivalling our most luxuriant hedge-banks; while in the hollows or dry ditches at their base the burdock, thistle, knapweed, wild rose, sweetbriar, brambles, and a lrost of other plants, grow freely.

Having arrived at the bottom of the lane, we are in the "Howth Road;" we must now turn to our left, and, continuing a short distance along the road, take the first turning on our right, at the bottom of which is the Sandy Beach of Sutton; turning to our left, and 
continuing our course along the beach, keeping by the sea wall, we shall soon see on our left a large heap of bricks, the remains of an ancient brick-kiln ; just past which we shall see a deep hole, of some considerable size, at the further end of which is a large pond; this hole was for two seasons the "Ultima Thule" of my explorations-this is the "Hilly Field of Ireland." The soil is limestone, and is covered with an infinity of plants of all kinds; the ground is literally carpeted with the "bird's-foot trefoil" (Lotus corniculatus), which here grows luxuriantly; together with Anthyllis Vulneraria, Matricaria Chamomille, Centaurea nigra, burdock, Veronica, Heracleum sphondylium, Plantago maritima and lanceolata, and an immense number of other plants; and the steep slopes upon the beach are clothed with verdure in a similar manner and of a similar kind, down to within a short distance of high-water-mark; while the edges of the slopes are fringed with old black-thorns (among which Eudorea lineola occurs), together with white-thorn, brambles, broom, \&c.

Following the main path, bearing to the left, we shall soon see on our right a lodge-house; a little past which, and in front of us, is a gate or stile; on passing over which we are in a wild, uncultivated, damp field, overgrown with brambles, furze, broom, honeysuckle, and a great variety of undergrowth of herbaceous plants; crossing this field we come to a stone wall in front of us, but if we look in the right-hand corner we shall see a few stones placed, after the manner of steps, in the wall ; ascending these, and jumping down to the other side, into a lane, we turn to the right, continue our 
course to the end of the lane, and, turning to our right again, we are in the straight road to the "Baillie Tavern" and the "Baillie Lighthouse ;" while on the left of the road we see the "Hill of Howth" in all its wild heathery beauty. But we will not at present digress from the straight road to the "Baillie." If we continue our route straight along the road for about a mile, or a mile and a quarter, we shall then see on our left, a little way up the hill, off the road, a small tavern; and at the end of a narrow road, a little distance further on, we shall see a board placed high above our heads, on which is inscribed "To the Baillie Tavern ;" continuing straight along the road we have come for a little distance further, we shall see before us a stile by the side of a gate, and the "Baillie Lighthouse" in the distance, at the bottom of the road which leads from the gate to the lighthouse.

Having got over the stile we are now in fine collecting-ground; on our right the ground sweeps down to the sea in a series of terraces placed one below another, and in many places covered with sorrel (Rumex Acetosa) as thick as grass, in the leaves of which, in places where it is sheltered by brambles, or on the lee side of the ridges and inequalities of the ground, the larvæ of Nepticula Acetose may be found in abundance; while among Dactylis glomerata, in the same localities, the new Elachista flavicomella may be found running up and down the stems of the grass, and making short excursive flights, but never quitting the shelter of the brambles; and here Mr. Hogan's specimen of the rare Elachista triseriatella was captured. Nearer the lighthouse the vegetation becomes of a 
different character; here, instead of the sorrel being in profusion, the thrift (Statice armeria) predominates, the ground being literally matted with its roots; together with the curious

\section{"Sea lavender that lacks perfume:"}

the flowers and flower stalks of which retain almost all their colour and beauty when dried, and are on this account used by the bird-stuffers to decorate their cases of birds, and also for the purpose of making winter bouquets; while the former (Statice armeria) may be commonly seen used as bordering for the flowerbeds in gardens, but is not much appreciated, on account of its creeping roots, which soon find their way where they are not wanted, and thus annoy the gardener :

"Tis this which rustic neatness leads

Round the trim garden's walks and beds,

Whose globe-like tufts of blossoms throw

O'er the green marsh a rosy glow,

Nor less when Alpine regions lift

Their misty tops-the hardy thrift."

Here Sericoris littorana, cespitana and lacunana occur, together with Argyrolepia Badiana and Gelechice tricolorella and fraternella, and Cemiostoma spartifoliella. Continuing our course round to the left, keeping "Dublin Bay" on our right, we have a fine collecting-ground on each side of us, for above four miles, until we arrive at "Howth Harbour."

But let us direct our steps towards the "Hill," returning to the stile over which we got to arrive at the "Acetose" ground; we must again betake ourselves 
to the main road, and, turning to our right, turn our backs upon the bay, and, having the gate and stile on our right hand, continue our course for a little distance, when we shall see a stile on our left; crossing this, and likewise the field into which it leads, we shall find ourselves in the "Old Road," with the Hill before us, into which we may obtain access by any of the rumerous gaps we shall see in the walls that bound it and the road.

Having now reached the "Hill," a short description of its characteristics may not be out of place. The "Hill" - or rather the " Hills of Howth," for the "Hill of Howth" is composed of two, of which the highest is called "Dun Hill" - is a wild uncultivated tract of land, of which the surface soil is a black heathery loam, on what appears to be a subsoil of limestone; it is covered with a luxuriant growth of heather (Erica cinerea and Erica tetralix), intermixed with Vaccinium Myrtillus, honeysuckle, bramble, stunted sloe bushes, sallow, \&c.; while the plants of lowly growth comprise Hypericum perforatum, Veronica and Thymus serpyllum; and the wet boggy places, which are thickly scattered about, produce, in addition to a goodly crop of rushes, Veronica beccabunga, Myosotis palustris and peppermint. On the margin of the Hill are three good plantations, which, although of young growth, produce many insects. One of these plantations is situated in the lowest and wettest position, and is composed principally of alder, birch and pine; of the other two, on the other side of the Hill towards "Howth Castle," the residence of Lord Howth, one is composed of birch, small oaks and spruce fir, and 
the other principally of beech and birch, intermixed with a few pines; the underwood of all of them is very varied, comprising brambles, fern, broom, furze, sloe, sallow, \&c., while the plantation nearest the castle is nearly surrounded on the "Hill" side with a hedge of broom; and, on the surface of the Hill, a great number of large masses of stone are scattered about, covered with mosses and lichens. Having ascended "Dun Hill," which may be distinguished by its having a tall pole planted on its summit, the view from thence of the surrounding country is magnificent; before us, on the opposite side, lies Kingstown, and in the distance the Wicklow mountains, the most conspicuous of which are the two apparently in the centre, at a little distance apart, and of a conical shape; these are the "big" and "little Sugar Loaf." On the left, stretching away along the coast, lies Killiney and the bold "Bray Head;" while to the right stretches the "silver" strand" of Baldoyle; and, far away in the distance, may be seen, if the weather be favourable, the "Mourne Mountains" in the county Down, and at our feet the sandy strand of Sutton meets our gaze. If we turn around and view the scene behind us it is almost equally beautiful. To the left is situated "Howth Castle," and the town of Howth with its commodious harbour, which in the herring season is filled with fishingsmacks; alas! how few of them owned by Irishmen! while a little way out in the sound is situated "Ireland's Eye," and further out, to the right, the almost barren island of "Lambay," while all around us lies the beautiful Bay of Dublin, its water's sparkling in the sunlight like molten silver. 
Often have I sat upon the summit of "Dun Hill," and enjoyed the glorious prospect, the cool bracing sea breeze, as it played gently over the hill, tempering the sultry atmosphere of a July day.

But let us return to our starting-points-Sutton strand, and the Hilly Field of Ireland. Here among the wild chamomile (Matricaria Chamomilla) Homoeosoma nimbella occurs, while among the bird's foot trefoil (Lotus corniculatus) we shall find Coleophora discordella; and among the knapweed (Centaurea nigra) Coleophora alcyonipennella may be found.

Among the broom on the edge of the slopes we shall find Depressaria costosa and assimilella, together with Cemiostoma spartifoliella; while, among the Centaurea, Depressaria liturella occurs.

In the Howth road, and in the lane leading from the Baldoyle and Sutton Station, on the turf walls among the broad leaved mouse-ear chickweed (Cerastium vulgatum) we may find Gelechia fraternella, while Depressaria applana occurs among the Umbellifera (Charophyllum), \&c.

In the Hilly Field we shall find Tortrix Icterana (males) and Lozopera dilucidana, together with the larvæ of Gracilaria tringipennella, mining in leaves of ribbed plantain (Plantago lanceolata); while the conspicuous black larvæ, with white spots, of Tortrix Icterana (producing females orly), may be found on the same plant rolling up the leaves tubularly.

Among the sea plantain (Plantago maritima) the variable Gelechia instabilella occurs, while Nepticula Aurella occur's among brambles; and the pupæ of 
Depressaria Heracliana may be collected in the stems of the neighbouring cow parsnips (Heracleum sphondylium).

In folded leaves of (Centaurea nigra) we shall find the larvæ of Depressaria arenella, while mining the leaves of Anthyllis vulneraria the larva of Gelechia Anthyllidella occurs; and in the leaves of the brambles, making large blotches, we shall find the larvæ of Tischeria marginea, while in the leaves of the hawthorn and sloe, the larva of Ornix Anglicella occur's, together with the larvæ of Lithocolletis Corylifoliella on hawthorn, upperside, and $L$. pomifoliella on the underside; while in the leaves of the sloe the larvæ of Lithocolletis spinicolella may be found.

In the rough uncultivated field by the Lodge house Notocelia Udmanniana occur's among brambles, and the larvæ of Lithocolletis trifasciella may be found in honeysuckle leaves.

In the straight road leading to the Baillie Tavern and the Baillie Light House, in the wet ditch by the road side, may be found among the flea bane (Inula dysenterica) the pretty Acrolepia granitella; while in the hawthorn leaves in the hedge-row may be found the larvæ of Nepticula Oxyacanthella and ignobilella, while in a small mine in the hawthorn leaves, and feeding externally, may be found the larvæ of Bucculatrix Cratcoi.

Near the Baillie Tavern, if we climb the looselybuilt stone wall on the left of the main road, we shall find ourselves in a dry ditch filled with a profusion of vegetation, consisting of Stellaria holostea and uliginosa, Cerastium vulgatum, brambles, furze, broom, 
honeysuckle and Hypericum perforatum. Here may be found Gelechice fraternella and tricolorella, Gracilaria auroguttella, Catoptria Ulicetana, \&c. The insects occurring in the Acetosa ground have been already enumerated.

Let us now push forward to the Hill and its plantations. In the wet places on the Hill we shall find Bactra lanceolana, together with Crambus pratellus, pascuellus and culmellus, while among the Atriplex and Chenopodium, growing under the walls of the plantation, we shall find Coleophora annulatella; while the beautiful Plusia Iota may be occasionally beaten out of the heather; and upon the bilberry (Vaccinium Myrtillus) the larvæ of Coccyx Vacciniana may be found in plenty: "July 18th, larvæ on Vaccinium in plenty."

In the plantations we shall also find plenty of our little pets.

In the leaves of the alders, the larva of Lithocolletis alnifoliella abounds; while on the birch we shall find the larvæ of $L$. ulmifoliella, together with the larvæ of Nep. argentipedella; and on the oak the larvæ of Lithocolletis quercifoliella and Messaniella, together with the larva of Gracilaria Swederella in cones on oak leaves.

On beech the larvæ of Lithocolletis Faginella occurs, while on the trunks of the trees we shall find Coremia didymaria and Polypogon grisealis; while among the plantain (Plantago lanceolata) Botys etialis will be found, together with Aglossa pinguinalis on the stone walls.

Among the wild roses in the plantation nearest 
Howth Castle, we shall find the larvæ of Nep. anomalella, while on the hawthorn, in their curious gallery-like webs, we shall find the active larvæ of Swammerdamia pyrella; while in gardens on cabbages, \&c., we shall find the larvæ of Plutella Cruciferarum, and in fungi on hornbeam we may perhaps find the larvæ of Tinea corticella.

In the leaves of elms on the Malahide road, near Clontarf, we shall find the lar'v of Lithocolletis Schreberella, together with the larvæ of Nepticula marginicolella; and in the leaves of sloe, further along the road, near Dunnycarney, the larva of Nep. plagicolella occurs, together with that of Lyonetia Clerckella in the leaves of the wild apple (Pyrus Malus).

The slopes of the Dublin and Drogheda railway, from Clontarf to Howth, afford fine collecting. On these I have taken Elachista cygnipennella, Eupocilia atricapitana, Dicrorampha plumbagana, plentifully, and D. Ulicana, one specimen, together with Stigmonota perlepidana; and in a mixed hedge, just off the line near Raheny, the rare Lithocolletis irradiella was captured.

And now, dear reader, let us transport ourselves, in fancy, to some well-wooded spot on English soil, and, armed with beating-stick and net, pursuing our pleasurable occupation. What is that pretty insect that skips so lightly in the sunshine over the tall grass, its black and white markings forming a bold and pleasing contrast? That is Arge Galathea, while that large butterfly you see sporting round those elms is Vanessa polychloros; while flitting along the hedge-row, or 
settling on nettles and thistles, the beautiful Vanessa Urtice and $V$. Cardui may be seen.

But give those elms a stroke or two with your beating-stick. Ah! What is that green insect with large brownish blotches on the front and hind wings? Catch it! 'That is Phorodesma bajularia; the laryæ are case-makers, and feed on elm. The very scarce Phorodesma smaragdaria also occurs this month in open spots in woods among the yarrow (Achillea millefolium).

Among oaks the beautiful Liparis monacha occur's; while among plantain in woods we shall find Phragmatobia fuliginosa; and among sallows Orgyia gonostigma occurs.

In meadows Satyrus Tithonus occur's abundantly, while on chalky soils we shall find Satyrus Semele; and, soaring round the lofty oaks, we may see the prince of British butterflies, Apatura Iris, now making wide circles around the top of the tree, now alighting upon some favourite twig, and anon darting down to the margin of some pool of water for an instant, and as quickly resuming his exalted station at the oak's summit, while the handsome Thecla Quercus bears him company, like an attendant knight.

Among willows Scoliopteryx libatrix occurs, while on the licheny trunks of oaks Cleora lichenaria may be found; and among sycamores we slall obtain the pretty Stigmonota Trauniana, while the larvæ of Tortrix viburnana may be found securely rolled up in the sycamore's ample leaves, on which it feeds.

Among elms; sheltered in the holes or crevices in 
the trunk or bark, we shall find Cosmia affinis, and in hedge-rows Euperia trapetzina occurs.

But what are those little larvæ mining the leaves of those thistles (Cirsium palustre) at our feet? They are the larvæ of Gelechia acuminatella. Those blotches or lithocolleti-form mines on the underside of those nut leaves, and those turned-down corners on the same leaves, are the work of the same larvæ at different ages-this is the larva of Ornix Avellanella, which, when young, mines the underside of the leaves, but when older turns down the corners; on birch leaves we shall perceive similar turned-down corners, the work of Ornix Betulae, while on the leaves of the sloe and apple we shall see the similarly constructed residences of Ornix torquillella and Ornix guttea.

In the leaves of the woody nightshade (Solanum dulcamara) we shall find the larvæ of Gelechia costella; while in the stems of Chenopodium and Atriplex the larva of Gelechia obsoletella occurs.

But what is that beautiful insect with scarlet marking, flitting about in that sand pit, apparently intent upon finding a snug place to hide itself in, as we have driven it from its late place of rest? That! why never? Yes! it certainly is Hypercallia Christiernana! Well, who would have thought it? This is a lucky spot! Let us search again. Agreed! Beat this old furze. Crack, crack! another slice of luck! Upon my word it is nothing less than Ecophora Lambdella. Well, after this, whatever else we may take to-day will certainly not eclipse these.

Among thistles we may find Depressaria Carduella; while $D$. Hypericella occurs among the St. 
John's wort (Hypericum perforatum), among which also you will find the handsome little Gracilaria auroguttella; while among sallows Gelechia sororculella and Psoricoptera gibbosella occur, together with $D e-$ pressaria conterminella.

Among juniper bushes we shall find Depressaria pulcherrimella and the striking Ypsolophus marginellus; while, among Genista tinctoria, Gelechia lentiginosella and Anarsia Geniste occur: the latter has also been bred from broom by Mr. Machin (Zoologist, p. 4i46).

Among birches we shall find Padisca Solandriana, Harpalyce ruptaria and Geometra Papilionaria, while Camptogramna bilinearia may be taken in every hedge-row.

On old walls and palings Bryophila perla may be found, while on palings and tree trunks Miana literosa, Polia dysodea and Xylophasia lythoxylea may be met with, together with the beautiful Eupithecia pulchellaria.

On heaths in the north of England Anaitis imbutaria occurs; while Gelechia Hübneri may be found on the trunks of oaks also in the north.

The tyro, who may wish to diversify his employment, may profitably do so by pupa digging; the latter half of this month is the best time for the operation, as by then the greater part of our spring and summer feeding larvæ will have arrived at the pupa state, the perfect insects from which will appear in the autumn.

But no tyro should commence pupa digging unless he have a good stock of patience, and, I may add, 
good temper. It is rather disheartening to a young beginner to turn over the earth at the roots of several, perhaps a great number of trees, and find nothing to reward him for his trouble; but he must not give up, but keep steadily at his work and remember the lines-

"If you find your task is hard, Try, try, try again;

Labour brings its sure reward, Try, try, try again.

He must keep cheerily on and he will doubtless, after his day's work is done, find himself in possession of a goodly number of pupæ, which, if he had allowed his energies to be cooled by the unproductive trees, would still have remained snugly ensconced in " mother" earth," instead of finding a "local habitation and a name" in liis pupa-box.

In digging for pupæ the young Entomologist need not try every tree he comes across; it is useless to try young trees of any kind, large timber trees being most favoured by Lepidopterous larvæ; and all species of trees are not alike productive of pupæ, and some more productive at one season than another: thus the oak produces the greatest quantity of summer species, and the beech and poplar the greatest quantity of insects that pass the winter in the pupa state. The Rev. Joseph Greene, in his admirable paper on "Digging for Pupæ of Lepidoptera" (Proceedings Entomological Society, April 4th, 1853), observes, "The trees which I have found the most productive are the following:-elm, oak, ash, poplar, beech and willow. I never found anything at birch, maple or chestnut. 
Perhaps a short list of a few of the pupæ obtained at these trees may prove interesting."

"Elm.-Snerinthus Tilia (why this insect should be called the lime hawk-moth I know not; I have found dozens of pupæ at the roots of elm, but not one at lime), Petasia cassinea, Teniocampa rubricosa, $T$. Populeti, T. munda, Cosmia diffinis, Xylina semibrunnea, Anisopteryx ascularia, to and + , Hibernia leucophearia, $t$ and $q, H$. aurantiaria, $\delta$ and $q$, \&c.

"Oak.-Considering the number of larvæ that feed upon oak, I have been surprised at finding so few pupæ at it. This, I suppose, is partly owing to the fact that a considerable number of the insects whose larvæ feed upon oak do not pass the winter in the pupa state. However, when you do succeed in getting one it is generally good, and I have found Notodonta trepida, N. Chaonia, N. Dodoncea, Geometra Papilionaria, Biston Prodromaria, \&c. I was much surprised to find, on two occasions, the empty cocoon of Cerura Vinula on the trunk of an oak.

"Ash.-Precilocampa Populi, Acronycta Ligustri, Geometra lunaria, G. illustraria, \&c., \&c.

"Beech.-This and the poplar are the best trees. At the former I have found Lithosia rubricollis, $L$. aureola, Orgyia Coryli, Notodonta Camelina, Tephrosia consonaria, \&c.; at the latter Phragmatobia mendica, Poecilocampa Populi, Cerura bifida, $C$. furcula, Ptilodontis palpina, Notodonta dictrea, $N$. Dictcoides, Clostera curtula, Ceropacha Or, C. ocularis, Y psipetes ruberaria, \&c.

"The next point which may be considered worthy 
of notice is the mode of search. This, of course, varies according to locality. In digging it must be borne in mind that all pupæ are close to the trunk of the tree, seldom more than two, inches distant. Frequently the trunk of the tree forms one side of the cocoon, especially the cocoon of such insects as spin. Again, pupæ lie close to the surface of the earth (I have seen those of Smerinthus Populi and S. Tilice half out the earth), the larva of Calocampa exoleta is the only one I know of that goes to a considerable depth. Insert then the trowel about three inches from the trunk to the depth of two inches or so, then push it to the tree and turn it up. If the soil be dry and friable without grass, knock it gently with the trowel, which will be sufficient. If, however, there be grass you must proceed more cautiously: take up the sod in the left hand, knock it very gently with the trowel, and those pupæ which merely enter the ground will drop out. To find those which spin you must carefully examine the sod, tearing the roots of the grass asunder. These are, of course, much the most difficult to find, the cocoons being generally the colour of the earth. I may here remark that it is useless to try sticky or clayey ground, the caterpillars being unable to penetrate it. In searching under moss the best plan is to loosen the edge, then to tear it gently off, observing whether any pupæ fall. Look at the trunk to see if anything adheres to it, and then carefully examine the moss itself. Experience alone will enable you to detect a spun cocoon.

"If I were asked which are the most likely trees, I should say those whose branches spread out towards 
the ground, since moths seldom fly to the high branches; those whose roots form an angle filled with loose dry earth, especially when covered with grass, and lastly those which have a loose thick moss upon them. Nothing, however, can be more uncertain than any rules in this matter. You will perhaps see ten elm trees to your eye exactly alike: at nine you may find nothing, at the tenth possibly twenty or thirty pupæ. I remember on one occasion trying a number of ash trees without the slightest success, and was about to give up the searching as hopeless when I resolved to try one more. At that one I found forty-six pupæ of Ennomos illunaria, and three of Pocilocampa Populi."

There is one locality to which I would direct the tyro's especial attention. On heaths, downs, in old gravel and sand pits, hidden among brushwood, and scattered about on the sea shore, we may often see large stones or boulders, and old trunks of felled trees, covered with moss, under which the pupa-hunter will often reap an abundant harvest. 


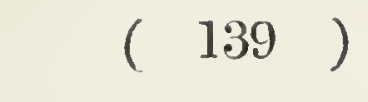

\section{CHAPTER VIII.}

\section{AUGUST.}

"What transport to retrace our boyish plays, Our easy bliss, when each thing joy supplied, The woods, the mountains, and the warbling maze Of the wild brooks."

"I care not, Fortune, what you me deny, You cannot rob me of free Nature's grace; You cannot shut the windows of the sky, Through which Aurora shows her brightening face; You cannot bar my constant feet to trace The woods and lawns, by living stream, at eve; Let health my nerves and finer fibres brace, And I their toys to the great children leave, Of fancy, reason, virtue, nouglit can be bereave."

"All hail! ye fields, where constant peace attends ! All hail! ye sacred, solitary groves !

All hail! ye books, my true-my real friends !

Whose conversation pleases and improves."

AND truly the contemplation of nature is delightful-soothing to the wounded spirit-elevating to the inquiring mind--peaceful to all; drawing the mind from the petty cares and frivolities of life, she opens out to the humble student her world of wonders, showing him beauty where he least expected it, use in the most 
apparently trivial objects, and fitness, adaptation and design in all.

It was remarked by the celebrated Dr. Johnson, on being told that a person whom he knew had destroyed himself, that "he never would have done so had he learnt how to hem a pocket handkerchief." Now to how many of the working men of this country, who now find the little time which they can call their own, after the labour's of the day are over, hang heavily on their hands, may this remark apply, many of them listlessly sitting in the chimney-corner with a pipe in their mouths, their thoughts of as little practical worth as the smoke that wreaths round their heads; some victims to ennui, not knowing how to spend their time or what to do, and many, I grieve to say, spending their time in a more than questionable manner to the profit of the publican and the degradation of themselves-to how many of this class would the study and contemplation of the works of nature bring happiness and contentment, raising them from the grovelling and debasing tendencies that kind of society into which a working man is usually thrown produces, expanding his intellect, giving him larger and more comprehensive views of the great plan of creation, and the relations we bear to each other and the world at large; and fostering in him habits of observation and reflection eminently calculated to make him a better citizen and a better man. The habits of order, reflection and energetic industry he will have acquired in the pursuit of Entomology (and indeed by all branches of natural history the same effect will be produced upon the earnest student) will tincture all his actions, and thus 
he will not only become more happy as a man but more valuable as a servant.

"The man who consecrates his hours,

By vig'rous effort and an honest aim,

At once he draws the sting of life and death!

He walks with Nature, and her paths are peace."

The scorching sun still holds sway over the earth; the teeming earth welcoming his smiles as it approaches fruition. The corn, now ready for the reaper, waves in the breeze, its heavy bending head giving signs of an abundant harvest, while the golden tints of the orchard promise a full supply of Pomona's dainty stores, while the stray fallen leaves, as they flit along our path, give evidence of the year's maturity.

And now, kind reader, let us visit another of the residences of our tiny friends, viz., "Charlton Sand Pit," and to this end we can take "the (once) silent highway" of the river Thames, or "travel over the unstable foundations of the Eastern Counties Railway, to further our object. If we choose the Thames we must land at Charlton Pier, and then turning to our right, and taking the Greenwich road, we must turn down the second turning to our left; we shall then find ourselves in Charlton Sand Pit, at the edge of which, on our right and above our heads, is the hanging wood. But if the speedier transit of the "rail" be our choice, we must obtain tickets for Woolwich, when we shall speedily find ourselves at North Woolwich, from thence we shall be ferried over the river to South Woolwich, when upon our leaving the pier and gaining the town, we must turn to our right, and continuing our course along the town and through, or rather between, the 
churchyards, and then past the dockyards, we shall soon enter Charlton, on the left hand side of which clean little village we shall see the celebrated sand pit and its hanging wood. Having now reached our destination, let us say a little respecting its peculiarities. Charlton Pit is a place which will try the patience of the tyro intent on adding to the number of the beautiful objects of which he is an admirer; for if the day be a little windy, farewell to all hopes of using the net within its precincts, for turn which way he will, and accommodate himself how he may to the different points of the compass, the wind will, with a strange perversity, ferret him out, and at last compel him to give it up in despair, unless he be made of sterner stuff than most mortals, or determines to assert in his own person the truth of the remark which has been applied to Englishmen of "never knowing when they are beaten." Or if he escape the persecution of the wind, another torment awaits him in the shape of the boys of the neighbourhood, who somehow seem to have an instinctive knowledge of a collector, for no sooner does one arrive in the neighbourhood than he unwittingly finds himself the centre of attraction to some halfdozen of these anything-but-to-be-desired assistants, who, as soon as he commences operations, mar the serenity of his temper by causing him to lose the first insect he attempts to catch in their anxiety to "see what the gen'l'mans (got?)."

But, however, Charlton is a good locality for many things. The soil is covered with a good growth of Artemisia, thistles, ragwort, broom, brambles, \&c., together with clumps of whitethorn, furze and sloe, 
while on the hill, in the centre of the pit, the larvæ of Arctia villica may be obtained plentifully in the spring months by raking them out from the roots of the Hieracium; while the hanging wood contains many fine old trees, together with a good undergrowth. Here the beautiful Cochylis dipoltana was first taken, and here too Gelechia acuminatella occur's, together with Depressaria nanatella and Parasia Metzneriella, while among broom we shall find Trifurcula immundella and T. squamatella.

Among grass we shall find Elachista Megerlella and $\boldsymbol{E}$. obscurella - while among the common reed (Arundo phragmites) in the Greenwich marshes Elachista cerusella occurs, together with its larvæ mining in its leaves.

But to leave Charlton and its Sand Pit, and to discourse of the species generally to be found this month.

Among Atriplex, Coleophora annulatella occurs; while among Helianthemum vulgare we shall find Laverna Staintoni; and among Epilobium hirsutum, Laverna Epilobiella and Anybia langiella occur.

In the leaves of willows, sallows and poplars, rolling the leaves into cones, we shall find the larvæ of Gracilaria stigmatella; while in rolled-up leaves of alders the larvæ of Gracilaria elongella occur, together with the larvæ of Plilcoodes frutetana, and the darkcoloured and sluggish larve of $Y$ psipetes impluviaria; it is desirable to keep the larvæ of $Y$. impluviaria by themselves, as, should the vegetable pabulum become distasteful to them, they make no ceremony in appropriating the Gracilaria larva to the purposes of nutrition. 
Between united oak leaves we shall find the larvæ of Gelechia triparella, while in the stems of Atriplex and Chenopodium the larvæ of Gelechia obsoletella occur; while on its leaves, under a loose web, the larvæ of Butalis Chenopodiella may be found.

In turned-down sloe leaves we may find the larvæ of Enicostoma lobella; while on sallows, alders, birches and oaks the larva of Dasystoma Salicella occurs. Those larvæ which have fed on oak or birch produce insects which may with truth be termed "rosy," those bred from sallows being in nearly every instance almost black.

In the leaves of the woody nightshade (Solanum dulcamara) the larvæ of Gelechia costella and Acrolepia pygmeana may be found; while in the leaves of hawthorn, apple, \&c., the larvæ of the pretty little Cemiostoma scitella may be obtained in plenty.

Among furze the conspicuous Depressaria Umbellana occurs; while among Centaurea nigra, Depressaria liturella and arenella occur' and Depressaria conterminella and ocellana among sallows.

Among sallows on Wimbledon Common we shall find Peronea Hastiana, together with its larvæ in abundance; this also occurs in other localities, such as Lewisham, Hampstead, Epping, the New Forest, \&c. I will now, in order that the tyro may not be disheartened at meeting with rebuffs and questionable treatment at the hands of "unprofitable companions," relate for his edification my own adventures in pursuit of the larvæ of Peronea Hastiana. It was in the year 1849 I first heard of the larvæ of Peronea Hastiana having been discovered; I therefore was anxious to 
obtain it, and, to this end, I made inquiries with all humility among those who I thought would be most likely to afford me the information as to its food and habitat, but without success.

It so happened that at this time I was acquainted with a collector, with whom I was upon very friendly terms, and in whose company I was very often. To my oft-repeated inquiries respecting the Peronea larvæ, I obtained no information, excepting that he was taking them by bushels! that a blue bag of the ordinary size carried by lawyers was nothing extraordinary to fill in one day's collecting. This startled me; collecting larvæ by bushels was a circumstance, in my Entomological experience, I had never met with, and which I did not, in my own mind, believe; but, however, no information as to food or locality could I obtain from my " unprofitable companion."

The winter passed over, and the summer of 1850 came; I still inquired about the Peronea larvæ, and, by great good luck, I casually learnt that they fed on sallow, and were found on Wimbledon Common. Here was a slice of luck! I was in ecstasies. I then lived in Larkhall Lane, Clapham; and I determined that I would have Peronea's of my own breeding that autumn. August came. One afternoon I determined upon an expedition after the Peronea larvæ; so accordingly putting a tin can in my pocket, which would hold about a pint imperial measure, I started on foot for the common. I had never been there before, so had to inquire my way, and, after sundry inquiries, I arrived at my destination. But where were the sallows? I could see none. But, however, 
I determined to take the windmill for a landmark, and search until I found them. Soon after arriving at the windmill I found some sallows; here was another point gained-there were the sallows, but where were the larvæ that could be collected by bushels? I could see none (I was a little early for the glut, it being early in the month); at last, after a great deal of searching, I found a folded leaf-opened it, found it empty; opened another, the same success; so on with another and another until I had opened several, until at last I found a folded leaf with a larva in it-hurrah, a prize! I was about to transfer him to my capacious tin, when lo, with a twist and a wriggle, he quitted thie leaf and dropped to the ground. Could anybody have seen me then, no doubt he would have noticed my jaw drop wonderfully: but never give up; where there is one, there usually are more; so I persevered, and before dark I had, I dare say, three or four dozen Peronea larvæ!

A week after this I again visited the common on the same errand, and was busily engaged in collecting larvæ of Peronea. Opening every leaf in order to see if there was anything in it, by which means I not only lost a great deal of time, but a great many larvæ, besides being kept continually employed in watching those I had got in the box, to prevent their crawling out, as I had disturbed their privacy, when suddenly a voice behind me shouted - "Hilloa, Dick! what are you about?" when, on turning round, I beheld an Entomological friend, who was bent on the same errand. "Collecting Peronea larvæ," said I. "Collecting Peronea larvæ! and is that the way you collect 
Peronea larvæ, opening every leaf to look for its tenant ?" "Yes, certainly," said I, " how would you know whether you had a larva or a lcaf unless you did?" "Well," returned my companion, " come with me, and I'll show you how to collect Peronea larvæ." So accordingly I followed him, and he soon taught me how to improve upon the Trishman's instructions to his friend, whom he was initiating into the mysteries of Donnybrook fair-"Wherever you see a head," said he, "hit it!" "Whercver you see a twistcd leaf, or one or more leaves, affixed close to the stem or the top of a shoot twisted or agglutinated, pick it, cut it off with your knife, and transfer it to your bag or box without examination." I followed his advice, and soon not only filled my box, but was compelled to convert my pocket-handkerchief into a temporary bag, which was soon filled. Here then was the solution of the difficulty which had perplexed me-collecting them by the bushel-i. e. leaves and all, many of them being untenanted.

In another week I again visited the common, and, having walked there and started early, I had been at work some time, and, having now procured a good sized bag, I was well up to my work, when I was again saluted by "Hilloa, what brought you here?" and, turning round, I beheld my "unprofitable companion," who had not deigned to give me the slightest information, although he was taking them by bushels. Not being particularly good-tempered with him, I answered, "My legs; what else do you think brought me here? no thanks to you that I am here at all." "True," he said; "it would have been a long while H 2 
before I had given you the information that would have brought you here." "It don't need a prophet or fortune-teller to divine that," said I ; and continued my operations, at which he was not slow to begin. Dinner time arrived, and we adjourned to the "Stag" to refresh the inner man. After dinner we again repaired to the common, when another collector appeared upon the scene. After the usual greetings, silence again ensued, each being intent upon his occupation, when suddenly my "unprofitable companion" broke the silence by exclaiming (at the same time giving a side-long glance at me), "I say, Z - if we have so many boys finding their way here, there won't be many Peronea's left for the old ones: they'll be carrying off common and all some day." To this sensible and philosophic remark, the other mumbled out, "Ye'es." Silence again for some time, when suddenly my " unprofitable companion" became very friendly and communicative. Coming close to me, he said, "I say, Dick, don't you see what Z- is about? He's picking larvæ off' blackberry, not sallow! Those on the blackberry are better things than those on the sallow; I intend following his example, and I'd advise you to do the same." Suspecting this sudden friendship, but not being able to rebut the assertion, I said nothing, but determined to watch their movements, at the same time picking larvæ off blackberry; when I very soon found that my suddenly friendly companion only picked blackberry when he thought I was looking, and sallow when I was not. So much for his friendly offices. His object in getting me to collect larvæ on blackberry instead of sallow was that, instead of ob- 
taining Peronea Hastiana, Peronea Abildgaardana should be my reward.

This is a fair sample of the usual kind of assistance given by a certain class of collectors to their younger "brethren of the net and pin." Whether it is conducive to the spread of science, or the cultivation of friendly feelings towards many of its followers, the reader can form his own conclusions.

"He who will not give

Some portion of his ease, his blood, his wealth, For others' good, is a poor frozen churl."

And now, kind reader, let us in fancy transport ourselves to some old wood or shady copse, peopled with insect life, or to some sandy coast fringed with the purple thrift (Statice armeria), while its loose and crumbling soil is bound by the roots of the sea plantain (Plantago maritima), among which the variable and uncommon Gelechia instabilella occurs, while its larva mines its leaves or bores into the stem; this larva also feeds on the annual sea-side goose-foot (Chenopodium maritimum). But what is that beautiful orange-coloured butterfly careering along so gaily? that is the clouded-yellow Colias Edusa, while that pale yellowish one, with the green tint on the upperside of the underwings, is Colias Hyale, and that sulphurcoloured insect with the pointed wings is Gonepteryx Rhamni.

Among Helianthemum vulgare, Gelechia sequax occurs ; while among Statice armeria we may perhaps find Gelechia Brizella.

Along the grassy hedge banks and fields the handsome Polyommatus Alexis may be seen flitting along, 
exposing their beautifully marked under-wings as they settle on the blades of grass and the clover tops, while the grizzled skipper (Thanaos tages) dashes along as if defying the eye of the tyro to follow his movements; and Vanessa Urtica, together with Satyrus Ageria and S. Megara, flit from plant to plant, giving beauty to the earth by their presence, and pleasure to the eye by the harmony of colour they present.

A remarkable instance of the utility of the study of natural history, as to its educational bearings on the arts, is exemplified by a passage in "The Life of Thomas Stothard, R.A." "He was beginning to paint the figure of a reclining sylph, when a difficulty arose in his own mind how best to represent such a being of fancy. A friend who was present said, 'Give the sylph a butterfly's wing, and then you have it.' 'That I will,' exclaimed Stothard, ' and to be correct I will paint the wing from the butterfly itself.' $\mathrm{He}$ sallied forth, extended his walk to the fields some miles distant, and caught one of those beautiful insects. It was of the class called the peacock. Our artist brought it carefully home, and commenced sketching it, but not in the painting-room; and, leaving it on the table, a servant swept the pretty little creature away before its portrait was finished. On learning his loss away went Stothard, once more to the fields, to seek another butterfly. But at this time one of the tortoise-shell tribe crossed his path, and was secured. He was astonished at the combination of colour that presented itself to him in this small but exquisite work of the Creator; and from that moment determined to enter on a new and difficult field-the study of the insect 
department of natural history. He became a huntcr of buttcrflies. The more he caught, the greater beauty did he trace in thcir infinite variety; and he would often say that no one knew what he owed to thesc insects; they had taught him the finest combinations in that difficult branch of art-colouring." From "The Life of Thomas Stothard, R.A."

Among ash trees we may, perhaps, find the rare Ennomos fuscanturia (several specimens have been taken by Mr. W. Kirby of Wandsworth), together with the rare Zelleria hepariella and $Z$. insignipennella; while among junipers the pretty $Y$ psolophus marginellus and Chrosis rutilana occurs.

Among the "dyer's grcen weed" (Genista tinctoria), we may find Gelechia lentiginosella, while among Anthyllis vulnerariu, clover, \&c., Gel. Anthyllidella occur's ; and in orchards and on orchard palings, the pretty little Gelechia albiceps may be obtained.

Among broom and furze Gelechia mulinella occurs; in houses, and on mossy palings and walls, we shall find Gelectia domestica, while among oaks (in the New Forest) we may obtain Gelechia humeralis; and on the trunks of lime trees Chrysoclista Linneella occurs.

The end of the month is the best time for collecting Peronea cristana and its varieties; this insect, which occurs in different places, far apart, and which is taken by collectors (by beating) far more freely than the congeneric $P$. Hastiana, is as great a puzzle as the famous Aleucis pictaria. On what does the larvæ feed? has been the question many years, a question which has 
hitherto received no satisfactory reply; how long it is to remain in statu quo is uncertain, but still I think that if some of our collectors, who take the insect year after year, would notice its habits a little more closely than they have hitherto done, we should not be much longer in the dark respecting it.

It occurs at Hainault Forest, Coombe Wood, Surrey, Whittlebury Forest, Northamptonshire, Birch Wood, Leatherliead Common and Fetcham Down, and in the neighbourhood of Belfast, in Ireland.

Among beech trees we shall find Peronea favillaceana, on the underside of the leaves of which, in a slight web, the larva feeds; while on their trunks we shall probably find Lithocolletis Faginella and Nepticula Tityrella.

In the leaves of Convolvolus arvensis we shall find the larvæ of Bedellia somnulentella, while on various umbelliferæ, such as Torilis, Sison amomum, Heracleum sphondylium, \&c., the sticky-looking larvæ of Chauliodus Chorophyllellus may be found; and in cones, on the under-side of the leaves of the "biting Persicaria," or "Water-pepper" (Polygonum hydropiper), we may find the larvæ of Gracilaria phasianipennella.

By sweeping we may perhaps obtain the very pretty little Goniodoma auroguttella (in the Isle of Wight). "The larva (figured in Fischer) feeds in an angulated case on the seeds of Atriplex (its case resembling in form and colour the rhomboidal perigone of the fruit); in autumn, when the larva is full fed, it attaches its case to the lower part of the stem of the foot plant, and, boring into the interior, spins a white silken cocoon 
there, leaving its case attached to the exterior of the stem; it remains unchanged in this cocoon during the winter, but in spring it assumes the pupa state, and the perfect insect appears in July (and August). According to the observations of Fischer and Mann, it fiequents only those plants which grow in very sheltered situations." (Entomologist's Annual, 1855, p. 68.)

In the leaves of Poa aquatica, growing in the Greenwich marshes, also at Southend, Hackney, \&c., we shall find the larva of Elachista Poce; while on the seeds of Angelica sylvestris the larva of Ecophora flavimaculella occurs; while mining in the leaves of oaks the larva of Coriscium Brongniardellum may be found, and Coriscium cuculipennellum in rolled-up leaves of privet. "Mr. Sang bred this, this summer, from a pupa, enclosed in a long white cocoon, in a rolled-up ash leaf." (Entomologist's Annual, 1856, p. 55.)

Among clover, at Ripley and Hainault Forest, we may perhaps obtain the rare Aplota palpella; this species is bred on the contineut from rotten wood, and is thus mentioned by Mr. Stainton (Entomologist's Annual, 1856, p. 53): "When at Hanover Herr Krössman gave me a specimen of the continental Balucella (which we hold synonymous with Haworth's palpella); it was twice the size of our specimens, but he assured me it varied in size from quite small to those unusual dimensions. This specimen he had bred from rotten wood!!"

Among alders the rare Gracilaria falconipennella occurs; $G$. tringipennella among the ribbed plantain H 5 
(Plantago lanceolata), and the pretty Gracilaria auroguttella among Hypericum.

Among sloe bushes we shall find Ornix torquillella, while Ornix Betula occurs among birches, and Ornix Avellanella among nut bushes.

Among bullrushes we shall find Nonagria Typha and on the trunks of elms the beautiful Cosmia diffinis may be found.

In the leaves of aspens (Populus tremula) the very curious and interesting larva of Phyllocnistis suffusella may be found feeding on the juice that lies between the skin of the leaf and the parenchyma; the mines are not at first sight perceptible, but when we hold the mined leaf between our eye and the light, looking along its upper surface, we see a tortuous shining track reflecting prismatic colours as if a snail had crawled over it-this is the mine of $P$. suffusella. 


\section{( 155$)$}

\section{CHAPTER IX.}

\section{SEPTEMBER.}

The year rolls on apace. As week after week expires, bright summer, though she still retains her throne, looks evidently towards more southern lands. There are voices and signs full of warning around usthe mysterious heralds of her speedy departure; yet not in grief does she leave us, nor with grief do we watch her vanishing; for, though glorious her presence, she gave us only sweet promises, the fulfilment of which now draws nigh. Her purpose is endedher task accomplished-and with the sound of her receding pinions blends a sound of joy. The fruit has ripened-the harvest is being gathered; who does not gladly exchange the trustful but anxious watching for the perfect fruition of hope? Thus it is throughout all creation-with animate and inanimate things alikefirst the promise, then the fulfilment, ever faithful; season succeeding season, generation following generation, whether of men, animals or herbs; each and all showing forth the unchanging spirit of nature, which, though flippantly lisped by earth-wise fools, is reverently named amongst the angels, being indeed a glorious manifestation of the might and mercy of , God. 
And now, dear reader, let us wander together amid the sights and scenes that betoken the year's decline. The fields are busy with the harvest, the brown moor is alive with grouse, the tangled cover in which the gaily painted pheasant struts proudly, in due time, perhaps, to form a dainty dish upon the squire's table - brought down by the legitimate barrel of the certified sportsman-or by the stick of the poacher, who, in his nightly rambles, has been drawn to its roostingplace by its short, oft repeated crow - while the plump partridge runs among the stubble of the cleared wheat field, or lurks amongst the sheaves. The woods are now beginning to assume a more sober tint, the bright green in which they shone in summer is deepening into a darker hue-the leaves of the oak and maple are becoming patched with brown-while stray leaves and small branches, torn off by the wind, strew the ground; and in the paths in the woods the pretty and curious little shrew mouse (Sorex araneus) is often found dead, nipped by the night frosts.

And now, equipped for hunting our " untaxed and undisputed game," let us betake ourselves to Hampstead's cheerful vale, and in the shady recesses of the "Bishop's Wood" spend a few profitable hours. But first let me give my readers some description of the locality to which I purpose conducting them.

Hampstead has long been known as celebrated for the purity of its air and the number of its laundresses ; while its beautiful heath has been, from generation to generation, the paradise of the inhabitants of "Cockaigne" and of landscape painters-and may it long continue to be so ; may its beautiful scenery never 
be marred by heaps of brick and mortar, called villas, into which the wind finds its way through the walls, and the inhabitants of which choice structures may think themselves well off if they escape death by the contraction of chronic rheumatism. But to proceed; Hampstead Heath is a large sandy elevated plain, on which many patches of furze, fern, broom, brambles, \&c., luxuriate; it is dotted over also by many patches of small trees, besides good hedge-rows, in which trees of larger growth are found, including some noble old oaks, elms and alders. Keeping the main road from the village of Hampstead (which may be reached by omnibus) across the heath in the direction of Highgate, we shall see a little off the road, on the heath, on our left, a group of tall firs (these firs are said to have been a favourite resort of Steele and Addison); and a little farther on, on our left, we shall come to the "Spaniards" tavern, to reach which, in the days of the "Spectator" was a pilgrimage, and to have a game of bowls on its level green the height of enjoyment. On the right of the road is situated "Caen Wood," the seat of the Earl of Mansfield, whose manly battles with the lord of the manor to prevent the enclosure of the heath deserve all praise; while on our left, a little further along the road, and separated from it by a field, we shall see a large and fine wood: this is the spot to which I purpose conducting my readers-this is the "Bishop's Wood," or the "Big Wood," Hampstead, as it is more generally called.

In order to gain access to the wood we must turn down the lane (the first turning on the left from "The Spariards," and nearly opposite the entrance gates of 
Lord Mansfield's demesne), and about half-way down it, on the right, we shall see a gate leading into the wood; if it should be unfastened, we have only to push it open and walk in, but if it should chance to be fastened, we shall see a large hole in it big enough for a man to pass through by taking his hat off: through this aperture we must therefore pass, and are thenceforth in the wood.

The wood is large, and is composed of hornbeam, oak, beech, birch, \&c.-oak and hornbeam preponderating, - while the undergrowth is very varied, consisting of sallow, privet, small black poplar bushes, sloe, spindle, brambles, honeysuckle, \&c.; while the herbaceous growth is abundant and varied, consisting of Solidago virgaurea, Chorophyllum, Hypericum, Pastinaca, broom, Heracleum, together with a great variety of smaller plants, Orchidea, rushes, \&c.; and the hedge banks surrounding it are carpeted with verdure; while in the centre of the wood there is a large cultivated field of three or four acres, usually sown with wheat, no unfavourable circumstance or feature to the Lepidopterist, especially at sugar.

Just past Caen Wood, on the main road to Highgate, we shall see a turning by the side of Lord Mansfield's domain: this is Millfield Lane, and leads from Hampstead to Highgate Rise, and is well worth visiting by the Entomologist; as in this lane alone, in this neighbourhood, have I as yet met with the larva of Nepticula angulifasciella sparingly on rose bushes, together with $N$. anomalella in abundance; and $L i$ thocolletis Coryli more sparingly on nut bushes.

In the wood, i. e. Bishop's Wood, on hornbeam 
(Carpinus Betulus), we shall find Lithocolletis tenella mining the underside of the leaves; the only other locality I know for this species is Epping Forest, while on a single sloe bush, among the underwood, near the brook, we shall find the larvæ of Nep. Prunetorum; this extremely local insect has only occurred hitherto at the locality in which it was discovered by Mr. Boyd, at Loudwater, Bucks. Among the sallows we shall find the larvæ of Nepticula Salicis in profusion, while on hornbeam the larvæ of Nep. microtheriella and floslactella occur; and feeding upon the same tree, and also upon oak, the beautiful green shagreened larvæ of Halias prasinana may be found; in sloe leaves the larva of Lithocolletis spinicolella occur's, while on sallow we may find the larvæ of Lithocolletis salicicolella, often sharing the same leaf with the larvæ of $N$. Salicis, together with the larvæ of Peronea Hastiana; while in the leaves of the honeysuckle the larvæ of Lithocolletis trifasciella may be found in plenty; and, mining in the leaves of nut bushes, and in turned-down corners of the same, we shall find the larvæ of Ornix Avellanella, while in oak leaves, in blotches, the larvæ of Tischeria complanella occurs, and that of $T$. marginea in blotches, in bramble leaves.

At sugar, we may take here Orthosia lota, macilenta and neglecta; together with Anthocelis litura and pistacina, Noctua plecta and Phlogophora meticulosa, Glaa raccinii and Spadicea. Among whitethorn we shall find Orgyia antiqua, together with its apterous female, on the trunks, while at rest on the trunks of the trees, or on the earth, we may occasionally find the 
large and beautiful Sphinx Convolvuli; in the year 1846 this beautiful insect swarmed throughout the country.

I have enumerated a few of the more prominent or uncommon species which occur here at this season, but no doubt, from its position and the great variety of its growth, the wood, if well worked, would produce an abundant harvest of rarities.

I will now pass to those insects which generally occur this month.

At Whittlebury Forest we may find Iyonetia padifoliella. Of this species Professor Frey, of Zurich, states: "I bred in August all these forms (L. prunifoliella, L. padifoliella and L. Albella) from one kind of sloe mine, with similar larvæ, and am disposed to unite them all as one species. The mine is broad, not narrow like that of Clerkella; Albella is very scarce, padifoliella the commonest. The pupa is suspended as in Clerckella." (Entomologist's Annual, 1856, p. 58.)

On the coast, among the "sea buckthorn" (Hippophaes Rhamnoides) Gelechia Hippophaella occurs, while among Chenopodium maritimum and Plantago maritima we may find the extremely variable Gelechia instabilella; and in similar localities, at Brighton, on the Cheshire sand hills at New Brighton, and in the Isle of Wight, Gelechia marmorea and vicinella, together with Gelechia celerella and vilella occur; while at Deal we may find Depressaria granulosella, and at Folkestone Depressaria ultimella occurs.

In wet places, among Inula dysenterica, we may find the pretty little Acrolepia granitella, while among alders Gracilaria elongella occurs, together with the 
rare Gracilaria falconipennella; while among Angelica sylvestris the delicate Depressaria ciliella may be found.

In houses those domestic pests Tinea fuscipunctella, pellionella and biselliella occur, together with the pretty Endrosis fenestrella.

But what is that mass of web on that hawthorn bush inhabited by? Surely not by spiders? Gro and see! touch it ! Hilloa, why what are those curious active creatures the larvæ of? They are the larvæ of Swammerdamia Pyrella; they never seem comfortable unless enveloped in a mass of web, in which they make a kind of tubular galleries, in the centre of which, on sunny days, they may be seen lying at full length-but touch the web, or approach a finger towards it, and hey! presto! off they are, either backwards or forwards, to the shelter of a neighbouring leaf.

In the leaves of Convolvolus arvensis we may find the curious and anomalous larvæ of Bedellia somnulentella; while, mining in the leaves of the wild hop, the larvæ of the small, but splendid, Cosmopteryx Drurella may be noticed.

If we examine the leaves of the "St. John's Wort" (Hypericum perforatum), we shall see many of them mined in an extremely circuitous manner, being nearly covered with a black mine; this is the work of the larvæ of Nepticula Septembrella (it occurs at West Wickham and at Headley Lane); while in cones on the leaves the larva of Gracilaria auroguttella occurs.

In cases among fallen leaves we may, by diligent search, find the larvæ of Incurvaria muscalella and pectinea; while in their curious cases, feeding under 
the leaves of the wild strawberry (Fragaria vesca), the larvæ of Lampronia prelatella may be found; it also feeds on Spircea ulmaria. "Mr. Wailes has found the larvæ of this species (Lamprosia prealatella) feedon Spircea ulmaria--a new food plant for this singular larva."--(Entomologist's Annual, 1856, p. 49.)

In cones on the leaves of oak we shall find the larvæ of Gracilaria Swederella, and on ash and lilac that of G. Syringella; while in the leaves of Artemisia vulgaris the larva of $G$. omissella occurs.

On Lithospermum officinale, at " Darenth Wood," the larvæ of Anesychia decemguttella may be found; while on Sedum telephium the larvæ of Hyponomeuta vigintipunctatus occur, and in the seeds of Angelica sylvestris the larvæ of Ecophora flavimaculella may be found.

In turned-down leaves of sloe we may find the larvæ of Enicostoma lobella, together with the larvæ of Y psolophus fasciellus, which " feed on sloe, doubling up the leaf and leaving an opening at each end, through which they hurriedly escape on any alarm, so that they are most easily obtained by beating the sloe bushes where they occur. The larva is yellowish grey - the head reddish ochreous-the second segment pale ochreousthe ordinary spots small and black; it is very lively, with a tremulous motion of the anterior segments."(Entomologist's Annual, 1846, p. 52.)

Among broom Chesias Spartiaria occurs, together with Depressaria atomella, and among pines Thera variaria occurs; while among the junipers at Mickleham, Sanderstead, and at Birch Wood, we shall obtain 
the conspicuous Thera Juniperaria, while commonly among underwood Thera simularia occur's.

On the coast at New Brighton, and in the Isle of Portland, Speelotis precox occurs; while among burdock we may obtain the handsome Gortyna flavago not uncommonly.

In the "New Forest," the "Isle of Wight" and at "New Brighton," we shall obtain Epunda Lichenea; at this latter locality this insect has occurred in plenty - "nearly 100 specimens of this insect having been taken at New Brighton in September, 1850."-(Zoologist for 1850, p. 2958.)

On the Sussex Downs we may perhaps be fortunate enough to capture the very rare Deiopeia pulchella.

Among elms we may meet with Xanthia gilvago, of which Guenée says, "It is very common in France, the larvæ feeding on the seeds of the elm."

A species (Xunthia ocellaris), very closely allied to it, and only recenily distinguished from it, frequents poplar's. Guenée says, "The larva lives in the buds of the poplars, and is almost as abundant as that or gilvago is on the elms."

On the flowers of the mullein (Verbascum Thapsus) we may find the larvæ of the rare Cucullia Lychnitis. Mr. Stevens in the Zoologist for 1845, p. 1142, states, "I have annually, for the last three or four seasons, obtained the caterpillars of this rare shark from off the leaves and flowers of the mullein, found in a chalk-pit at Arundel, in Sussex."

On sloe, nut, birch, hawthorn, bramble, \&c.; we shall find the larvæ of Coleophora paripennella; wlile feeding on the seeds of Atriplex the larva of 
Coleophora annulatella occurs, and that of $C$. argentula on the seeds of the yarrow (Achillea millefolium).

On roses in gardens, on the dog rose in hedgerows, and (in Ireland) on the Rosa spinosissima, we shall find the young larvæ of Coleophora gryphipennella; this is one of the few Coleophora larvæ that construct fresh cases as they outgrow the old ones. This is effected in the following manner. The young larva, finding from its increasing size, its habitation become too circumscribed, proceeds to remedy the inconvenience by providing a new one. To this end, having chosen a leaf on which to operate, it attaches its case firmly by the mouth or bottom part to the foot-stalk of the leaf at the extreme corner; it then mines between the cuticles of the leaf until it has made a blotch at the edge of the leaf of a semicircular shape of sufficient size to suit its requirements; it then commences cutting off the mined portion (turning round in its new case to effect its object), and fastens together with silk the edges as it detaches the mined portion from the leaf, and gives to its case a curved form as it proceeds towards the point at which it entered: having arrived here its task is accomplished, when it either lets itself drop in its new abode by a silken thread to the ground or a neighbouring branch, or crawls upwards according to its fancy, leaving its old case firmly affixed to the leaf stalk, and in this manner manufactures several cases in succession, according to its requirements, always leaving the old case sticking at the foot of the leaf from which its new abode was cut. Thus the tyro, whenever he sees a semicircular piece cut out of a rose leaf, and on its foot-stalk a small or 
moderate-sized case, may be sure it is empty. If, by any accident, the larvæ, in constructing its new case, should cause it, in cutting it off, to double upon itself, or otherwise make it untenantable, it directly withdraws into its old case, and, disengaging it, proceeds in search of another leaf on which to operate afresh.

On alders, birches, oaks and sallows, we shall find the fat larva of Dasystoma Salicella; while on oak, beech, \&c., the curious club-footed larvæ of Chimabacche Fagella may be found.

Among limes we may find the pretty Xanthia aurago, while among brambles the curious larvæ of Chrysocorys festaliella may be found. In the " Entomologist's Annual," 1856, p. 57, Mr. Stainton thus notices this larvæ: "Mr. T. Wilkinson, of Scarborough, sent me in September some larvæ of this species; and, subsequently, I found them at Bideford rather commonly. They feed either on the upper or under side of bramble leaves, eating the leaf half through, and making conspicuous blotches, which are very evident even when you are not specially looking for them. The larva agrees well with Hübner's figure, which is copied by Curtis."

Among the golden rod (Solidago virgaurea) we may find the larvæ of Botys terrealis feeding upon the flowers.

If, on some sunny morning, we examine closely the bottom of some old paling we may, perhaps, see some curious little mounds composed of grains of sand, small stones, pieces of the wing cases of beetles, bits of shells, \&c.; if we touch one of these mounds, we shall find that it springs to the touch, and, on detaching it, we 
shall see that it is a larva-case ornamented in this curious manner; this is the larva of Diplodoma marginepunctella, but what its food is at present is unknown. I have taken the larva some years back on Lord Mansfield's palings at Hampstead, but never succeeded in rearing the insect. In Mr. Stainton's "Observations on British Tineina" (Entomologist's Annual, 1856, p. 49), it is thus noticed: "Two of the curiously clothed larvæ of this insect have been sent me, one by Mr. Parfitt, of Exeter, in August, the other by Mr. Scott in September. Neither larva was seen to eat, so that the food still remains a mystery."

In woods among brushwood we shall obtain the pretty Phoesyle miaria, and in chalky localities the handsome Phoesyle Psittacaria may be found; now also appear Harpalyce achatinaria and Geometra angularia, while among the bush vetch (Vicia sepium) we may obtain the larvæ of the new and beautiful Lithocolletis Bremiella.

"This species was discovered a few years ago at Zurich by Herr Bremi-Wolff, in whose honour it has been named; the larvæ was detected mining the leaves of several species of Vicia. On the 26th of September last, I received several mines of this species from Herr Schmid, of Frankfort-on-the-Main, and, profiting by the information derived from the sight of these mined leaves, I visited, on the 28th, a locality near Bexley, where I was aware that Vicia sepium grew abundantly by the edge of a wood. In half an hour Mrs. Stainton and I had collected about thirty leaves containing larvæ or pupæ, and Mr. Douglas nearly as many--a striking instance of the ease with which new species 
may be added to our Fauna if we coach up the subject from those who are already skilled!

"The species is double-brooded, the larvæ feeding in July and September; many of the latter brood appear in the perfect state in October, while other specimens remain pupæ all thewinter." - (Entomologist's Annual, 1856, p. 40.) 
$168)$

\section{CHAPTER X.}

OCTOBER.

ОстовеR, herald of the falling year, has come,-the shortening days, - the lengthening nights, - the cold bleak winds, - the stormy blast as it sweeps along stripping the trees of their leaves, and strewing the woods with acorns and beech masts, providing a dainty meal for

"The restless wandering tenants of the sty:

From oak to oak they run with eager haste,

And, wrangling, share the first delicious taste

Of fallen acorn; yet but thinly found,

'Till the strong gale has shook them to the ground.

It comes : and warring woods obedient wave :

Their home well pleased the joint adventurers leave;

The trudging sow leads forth her numerous young,

Playful, and white, and clean, the briars among,

'Till briars and thorns increasing, fence them round,

Where last year's mould'ring leaves bestrew the ground,

And o'er their heads, loud lash'd by furious squalls,

Bright from their cups the rattling treasure falls."

Bloomfield's Farmer's Boy, Autumn.

Autumn calls up many reflections of the past happy summer time, when all was light and joy,--when perhaps with a youthful companion, in whose heart we wished to implant a love for Nature's beauties, and to 
draw forth the thinking and reasoning powers of his mind, we wandered through the leafy maze of some old wood, or trod the grassy carpet of the breezy down, -teaching him to observe and note for himself the various changes in the objects around him, and thus opening up to him a fund of instruction and amusement so vast that the longest life, or a series of lives, would fail to exhaust it; and this is within the compass of the mind of the young. The poet Wordsworth tells us of a boy who from his sixth year had been engaged in solitude in contemplating the starry firmament and the scenery around him, and bears witness to the good effect it had upon his mind. He says-

"While yet a child, and long before his time, He had perceived the presence and the power Of greatness : and deep feeling had impressed Great objects on his mind, with portraiture And colour so distinct, that on his mind They lay like substances, and almost seem'd To haunt the bodily sense. He had receiv'd A precious gift; for as be grew in years, With those impressions would he still compare All his remembrances, thoughts, shapes and forms;

And being still unsatisfied with aught Of dimmer character, he thence attained An active power to fasten images Upon his brain ; and on their pictur'd lines Intensely brooded, e'en 'till they acquir'd The liveliness of dreams."

"If we wish rural walks to do our children any good, we must give them a love for rural sights,--an object in every walk. We must teach them-and we 
can teach them-to find wonder in every insect, sublimity in every hedge-row, the records of past worlds in every pebble, and boundless fertility upon the barren shore; and so, by teaching them to make full use of that limited sphere in which they now are, make them faithful in few things, that they may be fit hereafter to be ruler's over much." *

And now, dear reader, let us take a trip together, and for awhile commune with green fields and shady woodlands, and to this end betake ourselves to the Eastern Counties Railway Station at Shoreditch, obtain tickets for the Ilford Station, at which, after about three quarters of an hour's riding, we shall find ourselves at Ilford en route for Hainhault Forest-now, alas! doomed to destruction, but which in days gone by was, with the adjoining forest of Epping, a choice hunting-ground.

Having reached the Ilford Station and alighted, we must, on leaving the station and gaining the town, turn down the lane on our left, when, continuing our course along it until we reach the bottom, we shall then find ourselves on the margin of the "Forest."

The forest is principally composed of elın, oak and hornbearn, together with a sprinkling of birch and a number of old whitethorn trees. This is the headquarters of the handsome and variable Peronea cristana in the London district.

Having reached our destination, let us commeuce operations, and, net and beating-stick in hand, make ready for the fray. Ah! what are those active brown insects darting about in and out the branches of those

* Kingsley. 
oaks? They are the males of Chimabacche Phryganella, and their apterous females may be found on the trunks of the oaks. The females differ considerably in colour from the males, being light grey, with a dark dash through their abbreviated wings. By beating the oaks we shall obtain the extremely variable Cerostoma radiatella, and perhaps the beautiful Coriscium sulphurellum likewise; while at sugar Calocampa vetusta and $C$. exoleta, together with Chariptera Aprilina and Miselia Oxyacanthe, occur; and by beating we may obtain Hibernia aurantiaria and $H$. defoliaria, while their apterous females may be found on the trunks of the trees. This latter species, $H$. defoliaria, is subject to great variation in the markings, some specimens being wholly of an orange colour thickly sprinkled with black atoms.

Let us now turn our attention to those species that will be most likely to attract the notice of the tyro this month, if he be really in earnest in his search; and let the Lithocolletides and Nepticule have our first attention. This month is the best time in which to collect them, the larva being now nearly if not quite full fed. On oaks we shall find the following species of Lithocolletis, Roboris, hortella, Amyotella, lautella, quercifoliella, Messaniella, Heegeriella and Cramerella, together with the following species of Nepticula, atricapitella, ruficapitella and subbimaculella. In hawthorn leaves we shall find the larvæ of $L$. pomifoliella on the under side, and L. corylifoliella on the upperside, together with the larvæ of $N$. pygmaella, Oxyacanthella, ignobilella and gratiosella; in sloe leaves, L. spinicolella, N. playicolella and Prune- 
torum; in beech leaves, L. Faginella and N.Tityrella; in birch leaves, L. ulmifoliella and the larvæ of the new species of Nepticula Betulicola. The larve is thus noticed in the Natural History of the Tineina, vol. i. p. 22:-_"An amber-coloured larva with green dorsal vessel, making a small contorted gallery, of which the commencement is filled with brown excrement, the latter half having the greenishgrey excrement only in the central portion."

In alder leaves, on the upperside, we shall find the larva of L. Stettinensis; while on the underside the larva of $L$. Frölichiella (distinguishable by its large mine and cocoon), and L. Kleemannella and alnifoliella, occur.

In elm leaves the larvæ of the beautiful L. Schreberella will be found, together with the yellow larre of the equally beautiful $N$. marginicolella, and the gutformed mine and green larve of the plain $N$. viscerella.

But let us for variety examine that clover-like plant with pea-like seed vessels growing on that hedge bank, the bird's-foot trefoil (Lotus corniculatus). We may perhaps see on some of the leaves white blotches. These are caused by the larvæ of Coleophora discurdella, and on turning over some of the blotched leaves we may find a larva in its small curved case, at present hardly the eighth of an inch high. This is an example of a Coleophora larva, which does not quit its case, and form a new one, as is the custom of Col. gryphipennella, but increases the dimensions of its case by adding new portions to the original one; and the manner in which this is effected is rather curious, and is as follows:- 
The young larva having outgrown its original case, proceeds to increase its capabilities of affording accommodation to its occupant by adding to its dimensions. To effect this object the larva having selected a leaf of its food-plant, attaches itself to the edge of it, and commences mining between the cuticles in a semicircular manner at the bottom of the mine, but starts off at right angles from the base of the old case, thus making the addition to its former case larger at the bottom or mouth than at the point of juncture of the old case, and giving to the whole a cornucopia-like shape. Having mined a sufficient depth into the leaf for its purpose, and drawn its old case for a little distance within the new mine, the larva lines the whole with silk, and, cutting off its improved habitation, it takes its departure. This process is repeated as often as necessary, the case becoming of course longer and broader at every addition, until the larva has become full fed. The edges of the several additions to the case by drying assume a curled form, thus giving to it in many instances a fringed appearance; while the newer additions, being much lighter in colour when fresh than the other portions, often give the structure a curious party-coloured patchwork appearance.

On the seeds of the yarrow (Achillea millefolium) we may find the larvæ of Eupithecia subfulvaria, together with the larvæ of Coleophora argentula.

If in places where the dogwood (Cornus sanguinea) grows we examine the leaves, we shall see many of them marked with large greenish blotches, and other's with holes in them cut out of the previously-mined places. This is the work of the larva of the beautiful 
Elachista Treitschkiella, which first mines the leaves, and then, spinning a portion of the two cuticles together, cuts out a small flat elliptical case, in which it descends to the ground in the manner of the larvæ of Lamjronia and Incurvaria.

Among bilberry (Vaccinium Myrtillus), on which the larvæ feed, we may obtain the rare Peronea Maccana; while on the same plant the larvæ of Coccyx Vacciniana may be found in many places in plenty, and in the stems of thistle (Cirsium palustre) the larvæ of Ephippiphora Circiana and Ephippiphora Scutulana may be found, Ephippiphora novana being merely a variety of the $f$ Scutulana. " $H$. novana is, I believe, merely a variety of the of Scutulana." (Entomologist's Annual, 1855, p. 51.) And in the stems of the wild parsnip (Pastinaca sativa) the larvæ of Lozopera dilucidana may be found.

On Wimbledon Common and at Hackney we may obtain the pretty Simaëthis scintillulana; while on nettles Simaëthis Fabriciana occurs in plenty, together with Pionea forficalis in gardens and weedy lanes.

On yew berries at Norbury Park, near Dorking, the rare Dasycampa rubiginea may be obtained; while in cultivated places, especially in the neighbourhood of potatoe fields, the large and curious death's head hawkmoth (Acherontia Atropos) occurs. This insect, like many of the Splingida, occasionally appears in large or unusual numbers, when it becomes an object of terror in the agricultural districts, all kinds of ill luck and misfortune being prognosticated by its appearance; while the curious markings on its thorax, representing 
an outline of a death's head, are not a little conducive to the popular superstition at one time, if not now, prevalent in Cornwall and some other parts of the country, that, if one of these insects entered a house, it was a sure sign of the early death of one of the inhabitants, with what truth may be surmised.

At Darenth Wood, among maple, the rare and curious Ptilophora plumigera occurs, while on trunks of trees Petasia cassinea may be found.

Among bee hives Galleria mellonella and Achroea grisella occur in too great plenty for the bee-keeper; while inside the grains of wheat, barley, \&c., the larvæ of Gelechia cerealella commence their destructive ravages.

Among sallows, willows and poplars, the larva of Gracilaria stigmatella occurs; and on the leaves of the poplar, on the upper side, we may find the curious fork-tailed green larva of Cerura bifida, while on the trunks of poplars Chelaria Hïbnerella will be found.

In houses Tinea ferruginella and Endrosis fenestrella occur; while in shady places, in woods among the biting persicaria (Polygonum hydropiper) Gracilaria phasianipennella may be found, and among alders the rare Gracilaria falconipennella occurs.

Among Chenopodium and Atriplex we may perhaps find the rare Butalis Chenopodiella, and on the seeds of the Atriplex the larvæ of Coleophora annulatella occur; while in the stems of the said plant, growing in very sheltered situations, we may find the lar'væ of the very beautiful Goniodoma auroguttella.

Among ash trees Zelleria hepariella occurs; while 
among privet and ash we may find Coriscium cuculipennellum; and among the traveller's joy (Clematis vitalba) Gracilaria semifascia may be found.

In the seeds of the Lychnis dioica we may find the larvæ of the pretty Dianthecia conspersa; while among Convolvulus arvensis, Bedellia somnulentella may be found.

In cones on the leaves of the oak, the larva of Gracilaria Swederella will be found, while mining in the leaves of the Artemisia, the larva of Gracilaria omissella occurs; and on the leaves of the St. John's wort (Hypericum perforatum) we shall find the larva of Gracilaria auroguttella, while mining in the leaves of the said plant, the larva of Nepticula Septembrella occurs.

In the leaves of the laburnum in gardens we may find the larva of the handsome and delicate Cemiostoma Laburnella, while in the leaves of the wild apple and birch(?) the larvæ of Lyonetia Clerckella occur in their long gallery-like mines; and among apple trees, in orchards, we may obtain the scarce Cerostoma asperella.

Among Chærophyllum Sylvestre, \&c., we may find the sticky-looking larvæ of Chauliodus Chrorophyllellus; while among the said plants Depressaria applana will be found, $D$. umbellana among furzebushes, and $D$. propinquella among thistles, together with Depressaria depressella among the wild carrot (Daucus carota), on the heads of which the larvæ of Semasia rufillana may be found.

On wild rose we may, perhaps, find the larvæ of Acronycta tridens; while on brambles the larvæ of 
Thyatira derasa may be found the beginning of the month.

On wild roses we shall find the larvæ of $N e p$, anomalella, together with that of $N$.angulifasciella. This latter larva does not continue mining in a gallery, but eventually forms a blotch upon the leaf it inhabits.

On the bugloss (Echium vulgare) we may find the larva of Anesychia bipunctella; while mining in the leaves of Chenopodium and Atriplex, the larva of the pretty Gelechia naviferella may be found. This is a species the collector should breed every season, as it speedily looses its beauty after death.

And now I would say to the tyro, do not imagine that because winter is approaching that it is a lazy time for the Entomologist. The reverse of this is the case-what between pupæ digging, searching rotten wood, fungi, stems of plants, \&c., he will find his time fully employed, and no doubt many rarities will be the reward of his industry. He must be ever watchful, and never let a chance escape him, from want of perseverance or from dilatoriness of observation, of adding to his store of knowledge.

One man walks through the world with his eyes open, and another with them shut, and upon this difference depends all the superiority of knowledge the one acquires over the other. 


\section{CHAPTER XI.}

\section{NOVEMBER.}

The year, with all its varied pleasures, joys and sorrows, sunshine and clouds, storm and calm, is drawing to a close; day succeeding day, week to week, month to month, in the onward course of time. We have almost arrived at that period when we cease (most of us) to derive pleasure from the contemplation of nature; we associate with the idea of winter an almost total cessation of animal and vegetable life, and consider it a dreary and unsatisfactory period - the death of the year-but is such really the case? are the winter months such a "tabula rasa," such a blank as some would fain make us believe. I think not: 'tis true the oak, the ash and the elm no longer exhibit to us their dense masses of foliage, and on the slender twigs of the birch the beautiful leaves have ceased to vibrate, glancing and sparkling in the sunlight; and the gaunt figure of the poplar, as he stands denuded of his leafy honours, looms heavily in the murky air.

The active and pugnacious redbreast has left the woods to pay his annual visit to the dwellings of man; the sprightly chiff-chaff, the black-cap and nightingale, have taken their departure for southern lands and sunny skies; while the bare hedge-rows expose to view the now-deserted nests, within whose mossy depths 
many a feathery songster (now carolling in far-off lands, or flitting along the woodside) was ushered into life.

But all is not barrenness, all is not desolation. Winter, though it robs the trees of their leafy mantle, clothes their branches and trunks in a garb of beautiful lichen, exquisitely pencilled and delicately carved; while the bright green mosses, as they clothe some rough hewn stone, dilapidated wall, or gnarled tree trunk, rival the emerald in beauty, and the stems and trunks of the sloe and whitethorn present, in their licheny coats of gold and orange, a picture of beauty such as winter alone can produce.

But not alone does the vegetable kingdom present to the eye of the observer a broad and varied field of beauty, but the insect world also braves the chilling blasts of the north, which, as if enraged that they should have been pent-up so long under the glorious summer's bounteous reign, sweep over the fields and woodlands with impetuous rush; for, on the hawthorn's stem, the small Cheimatobia Brumaria may be found at rest in the daytime, or seen flitting along the hedge-row in the evening in search of his apterous spouse; while, on the trunks of the neighbouring birches, the larger', but more delicate-looking, Cheimatobia borearia may be found, but their apterous females but rarely, although they frequent the same localities; and, dancing about in the fitful gleams of sunshine, the males of Chimabacche Phryganella sport their little day, while on the trunks of the oaks their stay-at-home consorts may be found.

On old palings, in the neighbourhood of Putney, we 
may find, by searching with a lantern at night, the delicate Exapate gelatella, whose female is also apterous; while in houses and in sheltered hedge-rows, and on palings, Tinea biselliella and Endrosis fenestrella will be found.

But not alone to delicate pencilling does nature confine her powers in beautifying the objects that gladden the sight in "November dark and drear ;" she has her" jewels for those that woo her-whose brilliant sheen reflects the light of the glorious summer, fondly regretted, anxiously expected-for on the honeysuckle the beautiful Lithocolletis trifasciella may be seen, gay in his brilliant garb of saffron-yellow, black and white, while among the oaks in the woods, and the evergreen oaks in the gardens, the brilliant and delicately pencilled Lithocolletis Messaniella may be found.

On the herbaceous plants, now fast fading before sturdy winter's piercing breath, many larvæ may still be found making the most of the litfle remaining time they have to complete their "jaw-work." In sheltered places, on the "ground-ivy" (Glechoma hederacea) we may find the young larvæ of Coleophora albitarsella, while on the leaves of the "greater" stitchwort" (Stellaria holostea) the young larvæ of Coleophora solitariella occur; and in their curious cases, on the underside of the leaves of the "wild strawberry" (Fragaria vesca), we may find the larvæ of Lampronia pralatella.

In cases, among fallen leaves, we may find the larva of Incurvaria muscalella and $T$. pectinea, and from the plants of Hypericum perforatum, in sandy shady 
places, a stock of the "cigars" of Gracilaria auroguttella \& Co. may be obtained; while in the leaves of the said plant we may find the larvæ of $N$. Septembrella.

In oak leaves, mining in the green patches, we shall find the larva of Nepticula subbimaculella; while in bramble leaves the wavy tracks of the larva of $N$. aurella, and the brown blotches of that of Tischeria marginea, may be seen, and in rose leaves we may find the larva of $N$. angulifasciella.

Winter is the period in which the seed, rotten wood, fungi, grass and lichen-feeding larvæ revel. The larvæ of many of the Ecophore, Tinea, Gelechice, Parasice, Dasycerce, \&c., revel in abundance, and only await the diligence and perseverance of the Entomologist to become his lawful prizes.

In fungi we may find the larvæ of Enplocamus Boleti and Tinea parasitella; in the seeds of the "flea-bane" (Inula dysenterica) we shall find the larvæ of Gelechia inopella and G. bifractella; while in cases, on the seed-heads of the "wild marjoram" (Origanum vulgare) the larvæ of Gelechia subocellea occur; and in the seeds of the burdock (Arctium Lappa) the larvæ of Parasia Lappella may be found, whereas that of Parasia Carlinella feeds below the seeds of the "common carline thistle" (Carlina vulgaris).

The rotten-wood-feeders are in great strength during the winter months, and are well worthy a diligent search by the Entomologist, for not only may many rarities be his reward, but it is not unlikely that new species may thus be obtained. And here I cannot do better 
than transcribe for the benefit of my readers Mr. Stainton's remarks upon this subject (in the "Zoologist," page 4180): he says, "Many Entomologists labour under the impression that there is nothing to be done during the winter months, at least among Micro-Lepidoptera. 'It may be all very well,' say they, 'for a beetle hunter to go poking into old stumps, and picking up moss, but that sort of game don't suit us.' So, as nothing is to be got by poking into old stumps, nobody thinks of looking, and so nothing is got; but is the assertion true? It has several times been recorded that Dasycera sulphurella feeds as larva under the bark of decaying trees: has it alone that habit? Where did (the late) Mr. Wing find the larvæ of Ecophora unitella last spring? In some old pea-stichs, which he had used in the formation of an arbour. Where did Herr Richter find the larva of Ecophora similella? Under the bark of decayed fir-stumps, which were brought to his house as fire-wood. Now, in order to discover the larvæ of the species of a genus, you must first discover that of one species, next assume that the habits of the others are similar, and look for them in the then most likely places. The larvæ of $C E$ cophor'a augustella, Woodiella, formosella, lunaris, Lambdella, subaquilea, Panzerella, tinctella, flavifrontella* and fiscescens are unknown, probably they are all rottennood feeders. Professor Zeller found $C E$. formosella rather freely last summer (that of 1853) in a woodyard, along with Ecophora unitella. This strengthens previous suspicions. Most of the other species appear,

* The larva of $E$. flavifrontella has been discovered since this was written. See ante, p. 98 . 
by their haunts, to frequent places where their larvæ might have fed upon decaying wood; $E$. Lambdella, originally found swarming in a furze bush, may feed in the decaying stems of the furze. If formosella and Lambdella won't tempt an Entomologist out in January, I don't know what will. And it should be borne in mind, that probably all these species feed, like Dasycera sulphurella, throughout the winter, so that from December to February, when other sport is scarce, is the very time to seek for the Ecophora larvæ. When the collector is weary of poking into the old stumps he can agreeably diversify his occupation by collecting Elachista larvæ, of which he had probably destroyed several by treading on them, whilst at work on the Ecophora larvæ. They are to be found mining the leaves of grasses, preferring such long grasses as grow in the shelter of a hedge, or at the foot of a tree; he may find a goodly variety, hardly two grasses containing the same larvæ. These, again, may be found throughout the winter."

Added to this, the observations of continental Entomologists go to establish the fact, that many more species besides those enumerated are rotten-wood feeders; thus (in the "Entomologist's Annual," 1856, p. 53), we read: "When at Hanover, Herr Krösmann gave me a specimen of the continental Balucella (which we hold synonymous with Haworth's Palpella); it was twice the size of our specimens-but he assured me it varied in size from quite small to those unusual dimensions. This specimen he had bred from rotten wood!" And again, Herr Schmid notices of CEcophora augustella, "the larvæ of this certainly in rotten wood" 
(idem). May not the larva of Ecophora grandis feed on the same pabulum? it may be inferred it does, from the habitat of the perfect insect "in one fence composed of a mixture of dead and living hazel and birch" (idem); while (at page 123, Entom. Annual, 1856), it is stated that Herr Krösmann "also rears Tinea arcella from rotten wood."

On old palings and licheny trunks of trees the larva of Solenobia inconspicuella may be found; while in rolled-up grass leaves, sheltered by the hedge-row, the young larva of Gelechia rufescens occurs.

In grains of barley, oats, wheat, \&c., the larva of Gelechia cerealella works destruction, and on the heads of rushes the larva of Coleophora caspititiella may be found.

In the stems of thistles the larvæ of Myelois cribrum and Ephippiphora Scutulana and Cirsiana may be found; the larva of E. Cirsiana also feeds in the stems of the knapweed (Centaurea nigra), while on chalky or sandy soil, in the roots of the Artemisia, the larvæ of Ephippiphora Foneana and Dicrorampha Artemisiana occur; while in the heads of the "teasel" (Dipsacus sylvestris) the larvæ of Penthina gentianana and Eupoecilia Roseana may be found.

In the stems of the wild parsnip we shall find the larvæ of Cochylis dilucidana, while among seeds, \&c., the larvæ of Endrosis fenestrella may be found.

This is the best time of the year to collect the pupæ of the Lithocolletides, as many of those species that feed only on the leaves of the upper branches of the trees may now be easily collected in the fallen leaves: of this class are L. Amyotella and hortella. All the 
species that feed on oak, with the exception of $L$. Messaniella, are now in pupa, viz.: L. Roboris, hortella, Amyotella, lautella, quercifoliella, Heegeriella and Cramerella. In hornbeam those of L. Carpinicolella on the upper, and tenella on the undersidc; while in alder leaves the pupæ of $L$. alnifoliella and $L$. Stettinensis may be collected, the former on the under, the latter on the upper side; and in the leaves of the "mealy guelder rose" (Viburnum lantana) the larvæ of Lithocolletis lantanella may be found (at Mickleham); while in the heads of the cotton grass (Eriophorum), lying on the ground, the larvæ of Glyphipteryx Haworthana may be collected (Mr. Edleston, in Zoologist, page 4654).

This is the best month for the collector to dig for the pupæ of those insects that appear in spring and summer, as if he leaves this operation later than the end of this or the beginning of next month, the pupæ (many of them) will, instead of becoming the lawful reward of his industry and perseverance, form only a "bonne bouche" for the mice, who have a wonderful knack in finding out their whereabouts, and appropriating the delicacy to themselves.

A great number of hybernating caterpillars may now be found by raking at the roots of primroses, docks and other herbaceous plants, also under moss, in company very often with the pupæ of Geometree and Bombyces; but if hybernating larvæ are taken at this time of the year, it will be absolutely necessary, in order to rear them, to keep them out of doors exposed to the weather, leaving them to take care of themselves (of course in suitable breeding-cages), for to attempt to 
rear them within doors will, in eleven cases out of twelve, be a failure, your kindness will only cause their death.

If the tyro should not have convenience for replanting the roots of those plants in which the various internal root-feeding larvæ are, it will be better for him to defer their collection until the spring, than to risk the loss both of his time and collected larvæ by collecting them now.

And now the time of year has arrived in which the tyro may look back upon the results and achievements of the past season; he has to arrange his captures, note remarkable species or varieties, together with anything he may have observed of their habits which may be likely to be useful to himself or other people; i. e. whether any leaf has been mined in a peculiar way? or any shoot been distorted in an unusual manner by a larva which has left the marks of its operations, but has itself decamped? whether any plant has been operated on by larvæ on which they have not been observed before? and, lastly, whether any marks of larvæ already known to you, but which you have not before observed in your neighbourhood, or of species for which you have been too late in distant localities, have been observed in localities nearer home than those in which they usually occur?

This last remark I think necessary, as I believe we frequently make excursions far into the country for the larvæ of many species that might be conveniently collected within a short distance of our residences, if we would only pay a little attention to entomological mat- 
ters when we do not make a professedly entomological excursion. Our business matters sometimes take us a little distance into the outskirts of town, and if we would only pay a little attention to these matters at those times, we should save a great deal of time thus wasted, which might be used advantageously in pursuit of those species that do not favour suburban localities. 


\section{( 188$)$}

\section{CHAPTER XII.}

\section{DECEMBER.}

THe year is now almost gone. The period of time is now drawing to a close, during which we have spentso many sunny, happy hours in the pursuit of those beautiful objects of Nature's handiwork, which, fragile and tender as they seem, are yet dispersed with no sparing hand over the earth during every period of the year from January to December, during the summer's fierce heat and the winter's biting cold. Some of our beautiful pets are to be found enjoying, in the manner assigned them, their brief span of existence-an existence which, however brief and unsatisfactory it may seem to us shortsighted mortals, is yet no doubt as full of enjoyment and pleasure to them as our more protracted and elevated existence is to us.

We have now put by our nets. The sound of the beating-stick no longer resounds through the woods and copses, waking the echoes far and near. The grassy turf, which a few short weeks ago felt so soft beneath our feet, now gives forth a cracking sound as it sinks under our tread; the robin as he flits along the bare hedge-top, his wings dropped at an angle with his body, looks remarkably cold and uncomfortable, his puffy body, the feathers on which stand on end, forcibly reminding one of a ball of worsted after it has been ope- 
rated upon by a playful kitten; the hedge-sparrow darts through the tangled mazes of the hedge, while the sober-coloured wren glides along the bank, popping in and out of the holes and through the herbage in search of hybernated Diptera and other small fry of the like kind; and the handsome and sprightly little goldcrest (Regulus auricapillus) beautifies the dark branches of the pine by his gay dress and sprightly motions.

But do the birds alone give life to the otherwise dreary scene? No! for on the trunks of the ash the pretty December moth (Precilocampa Populi) may be found, and on old palings at night Exapate gelatella may still be seen, while in houses Endrosis fenestrella still makes his presence known by immolating limself in the candle flame.

But although stress of weather has compelled us to lay up our nets in port, and Bombyces, Noctua, Geometre, Tortrices, Tinece or Pyrales do not fall into our nets at the gentle admonition of the beating-stick as during the genial summer time, yet we may equip ourselves with "the tin canister and glass jar," and betaking ourselves to the sheltered sides of woods, to grassy banks and hedge-rows, or licheny tree trunks and similarly beautified palings, reap a rich reward for our perseverance by obtaining the larvæ of many of the winter-feeding species, for the lar'væ or pupæ of all the species enumerated last month may be obtained during this, with the exception of the larvæ of Nepticula Septembrella, subbimaculella and angulifasciella, and Lithocolletis alnifoliella and Stettinensis; while 
in addition the larvæ of Gelechia affinis may be obtained in and among moss on old walls.

Having now got to the end of the out-door duties of the year, the tyro will no doubt begin to think of his carpet slippers, arm-chair and comfortable seat by the fire; and no bad place either, but only when the weather is so unfavourable to out-door operations as to render it useless labour to attempt them. In such a case he has no excuse to lead an idle life; he has his collection to overhaul-his breeding-cages to set to rights, and more to make or get made if he should be so fortunate as to need them; he has his notes of the various observations he has made during the past season to arrange, and by them, in a great measure, to direct the course of his next season's Entomological campaign : all things being favourable, new species and varieties of old ones must be eliminated from the bulk of his captures, and his various incomplete series filled up as far as possible, and the duplicates of all species of which his checks are full set aside for the benefit of his friends and correspondents.

And now I would whisper a word into the ear of the tyro at this juncture-a word of warning and advice.

We will suppose he has well picked over all his captures, and having satisfied the demands of his own collection, he has a goodly number of specimens left, all nicely pinned and set and disposed in rows in his store-boxes according to their varions species. $\mathrm{He}$ looks at them and admires them; they are all the fruits of his industry and perseverance, gained by many a hard day's and night's collecting, and reared by unwearying care and attention. The question suggests 
itself to his mind, What shall I do with them? And if he has not learnt his lesson well, the answer will be make all you can of them, barter, huckster and peddle with them--drive hard bargains-give as little as you can, and take as much as you can get. And if a certain something tells him this is not light, that it is not liberal, that it is not just, he smothers it by arguing that it is only the usual course, almost everybody does the same, and that many of our oldest Entomologists are not above practising it. But beware : the practice of huckstering, chaffering and bartering duplicates has been the cause of more lying and deception than anything I know of in the Entomological world; has caused more heartburnings, alienated more friendships, and gained for its votaries more ill-will, slander and backbiting, which has damaged their characters for year's, and thrown them considerably in the rear of the Entomological throng who have acted in a more liberal and brotherly spirit. And all for what? That he might have the pleasure of saying, "he had an insect that Mr. So-and-so had not; that he was willing to part with a few specimens if he could get something good for them, but unless he did he should not let them go." The collector who speaks and acts in such a manner has no part or lot in the science of Entomology. He does not bring his heart to the work further than so far as it fills his cabinet; he grudges his brother Entomologist any rarity he may have taken, and if the latter be a tyro or young beginner he will by fair or foul means obtain it from him, and chuckle over the action as if it were meritorious. Such are the actions, I grieve to say, of many of the collectors of the beautiful objects 
of the insect world, who, after having spent the greater part of their lives in collecting, are still human milestones on the Entomological road, their only use being to show in their own persons what Entomology was in their day. But "Excelsior" - a new school of Entomology has sprung up; men have begun to see that to practice conservatism in science is, in fact, to stand still, to become a human milestone for the liberals in science to pass by. Scierice is social not solitary. The man who considers himself able to prosecute successfully the science of Entomology by his own unaided inclustry, however indefatigable and persevering he may be, will find he has become the victim of a miserable delusion.

As entomological science is a social science, and cannot successfully be prosecuted except under these conditions of liberality, friendship and good-will, each being willing, as far as in him lies, witlout fee or reward exacted, to assist his "brother of the ret and pin," how is it that there is so much ill-feeling and want of charity among its votaries? The reason is obvious-ignorance is at the bottom of it. I do not mean to say unlearned or brutal ignorance, but mental ignorance; that kind of ignorance that breeds suspicion, that makes you consider every man a rogue until you find him honest-clicqueism-the ignorance that has instituted guilds and other institutions sacred to the middle ages, but which will not stand the full blaze of noon-day - the want of a liberal spirit, of a conviction, and a practical one too, that to reap knowledge you must sow knowledge- " cast thy bread upon the waters and thou shalt find it after many days," - as are thy actions so shall thy reward be, sooner or later. 
Now, with respect to the exchange of duplicates, I cannot do better than quote Mr. Stainton's opinion of the use of the list of Entomologists published in the Entomologist's Annual, 1856, in facilitating exchanges: he says, "But independently of this use of the list of Entomologists, it may also be extensively useful by enabling those who are far advanced beyond being mere beginners, to obtain some of those local species of which their collections are at present deficient. The Entomologist who lives in Sussex will never meet with Erebia Blandina, though he collect for fifty years. The Entomologist located in Argyllshire may be equally certain he will never there meet with Limenitis Sibilla. Now if the one collector meet with more Sibilla than he can use, he may as well give them away; and if the Argyllshire Entomologist meet with more Blandina than he wants, he will, in like manner, be no poorer from parting with what is a superfluity with him-yet each will be a gainer by the exchange.

"By the word exchange I do not mean that each obtains an exact equivalent for the hypothetical money value of the specimen parted with. A duplicate is something we do not want, its value to us is 0 ; if we attempt to bargain with a correspondent what he shall give us in return for our duplicate, we become hucksters and petty tradesmen. Many a young Entomologist, to my certain knowledge, thinks that by exchanging insects is meant parting with his duplicates for others of equal value; and, therefore, that in opening a correspondence by saying, 'I have got so and so, what will you give in exchange for it,' he is merely acting according to the customary practice of most of our 
distinguished Entomologists, but in this he labours under a great mistake--

'Freely ye have received, freely give;'

and he will find that the practice is to give away duplicates to others who may be in want of the respective species, w thout any stipulation with regard to exchanges.

"Directly he begins to 'drive a bargain' he gets a bad character, and 'mercenary,' ' greedy,' 'stingy,' are a few of the epithets that get freely applied to him behind his back, and it damages a man's career for many year's to get a bad character at first starting.

"No one will find himself a loser by obtaining a character for liberality." (Entomologist's Annual, 1856, page 12.)

In conclusion, I would remind my readers never to promise to send any particular insect to a correspondent without being certain of their power of doing so ; never promise in prospective, as it is ten chances to one you may not be able to keep your promise: I mean thus, "When the ivy is in bloom I shall be able to send you petrificata, semibrunnea, \&c." How do you know that when the ivy is in bloom you will be able to obtain such species? and if you do not, and therefore do not send them, you create suspicion, however much you might have felt yourself able, at the time you made the promise, to keep it. Never deceive a correspondent by any falsehood or misrepresentation, but "Be just and fear not." 